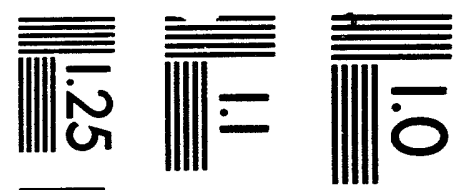

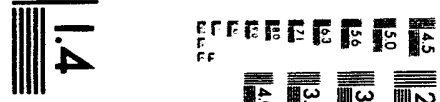

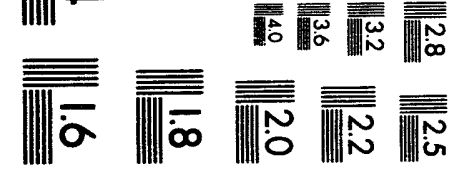



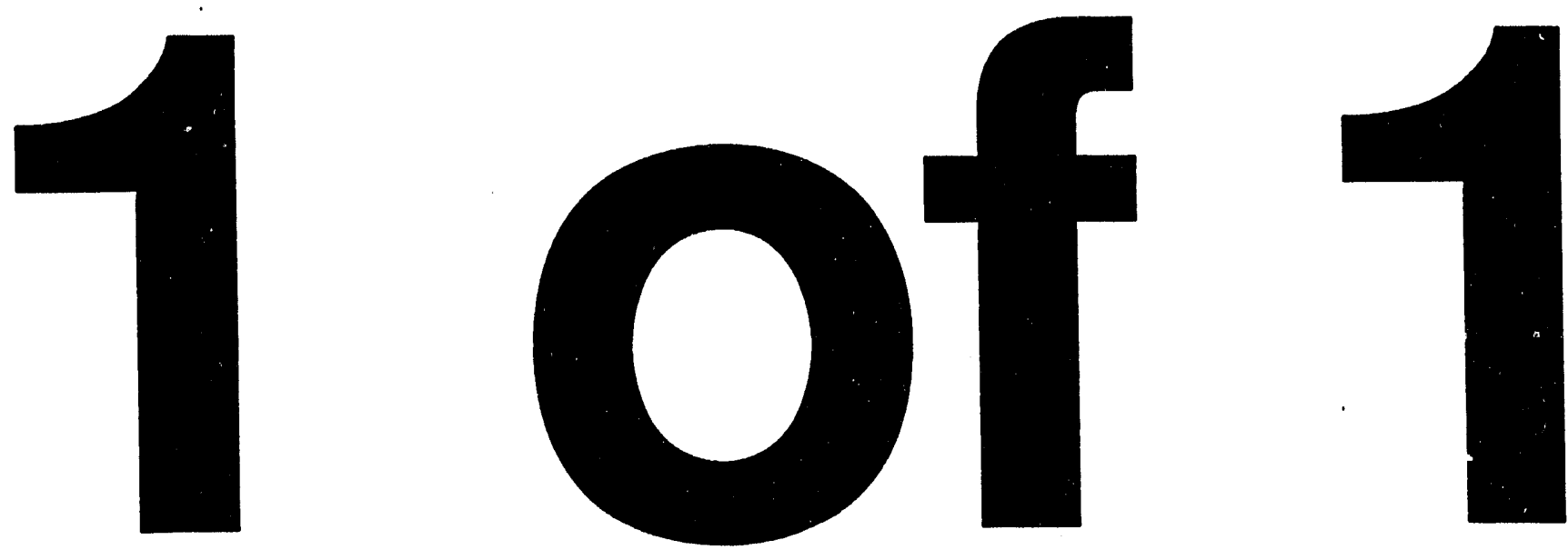


\title{
Habitat Types on the Hanford Site: Wildlife and Plant Species of Concern
}

\author{
J. L. Downs \\ W. H. Rickard \\ C. A. Brandt \\ L. L. Cadwell \\ C. E. Cushing \\ D. R. Geist \\ R. M. Mazaika \\ D. A. Neitzel \\ L. E. Rogers \\ M. R. Sackschewsky (a) \\ J. J. Nugent
}

December 1993

Prepared for

the U.S. Department of Energy

under Contract DE-AC06-76RLO 1830

Pacific Northwest Laboratory

Richland, Washington 99352

(a) Westinghouse Hanford Company

Richland, Washington 


\section{Executive Summary}

The objective of this report is to provide a comprehensive source of the best available information on Hanford Site sensitive and critical habitats and plants and animals of importance or special status, as defined in the "Hanford Site Baseline Risk Assessment Methodology" (DOE 1993a).

The information can be used in environmental evaluations for baseline risk assessments of the Site to determine the environmental effects of remedial actions and provide a basis for assessing the cumulative impacts of multiple actions. Pacific Northwest Laboratory and Westinghouse Hanford Company worked together to compile the information, which has been collected through basic research programs, monitoring programs, and educational endeavors.

In this report, sensitive habitats include areas known to be used by threatened, endangered, or sensitive plant or animal species, wetlands, preserves and refuges, and other sensitive habitats outlined in the Hanford Site Baseline Risk Assessment Methodology. Potentially important species for risk assessment and species of special concern with regard to their status as threatened, endangered, or sensitive are described, and potential habitats for these species identified. The following primary habitat types for the Hanford Site are shown on maps and described according to vegetation association and topography:

- basalt outcrops, scarps andi scree

- riparian streams and springs

- shrub-steppe on slopes

- sand dunes and blowouts

- abandoned fields/disturbed areas

- shrub-steppe on the Columbia River Plain.

Old-growth shrub-steppe habitat on the Columbia River Plain and on the slopes of surrounding hillsides provides important habitat for a number of plant and animal species of concern that depend on the shrub component, usually sagebrush, for nesting, food, and protection. Riparian areas associated with springs and streams and the Columbia River are also important habitat areas for many bird species of concern and for wetland-sensitive plant species. The relatively pristine Arid Lands Ecology Reserve provides important habitat for large and small mammals, birds of prey, and amphibians and reptiles that may not occur on the Columbia River Plain. Rattlesnake Ridge and Umtanum Ridge are potential areas of concern for several sensitive plant species.

Shrub-steppe and riparian habitat available for species of concern on the Hanford Site may become a more critical issue as agricultural, industrial, and urban development decrease the amount of these habitat types elsewhere in eastern Washington. 


\section{Contents}

Executive Summary $\ldots \ldots \ldots \ldots \ldots \ldots \ldots \ldots \ldots \ldots \ldots \ldots \ldots$ iii

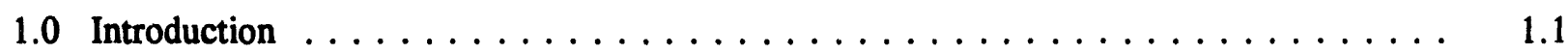

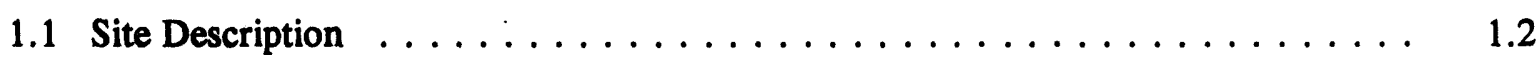

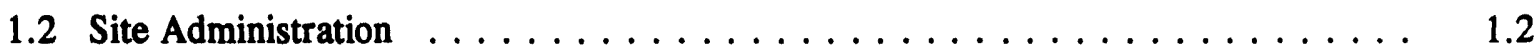

2.0 Shrub-Steppe Habitats on the Hanford Site $\ldots \ldots \ldots \ldots \ldots \ldots \ldots \ldots \ldots \ldots \ldots$

2.1 Basalt Outcrops, Scarps, and Screes $\ldots \ldots \ldots \ldots \ldots \ldots \ldots \ldots \ldots \ldots \ldots$

2.2 Riparian Habitats Along Streams and Springs $\ldots \ldots \ldots \ldots \ldots$

2.3 Sagebrush/Bunchgrass Habitats $\ldots \ldots \ldots \ldots \ldots \ldots \ldots \ldots \ldots \ldots$

2.4 Riverine/Riparian Habitat Along the Columbia River $\ldots \ldots \ldots \ldots \ldots$

2.4.1 Emergent Habitats and Wetlands $\ldots \ldots \ldots \ldots \ldots \ldots \ldots \ldots \ldots \ldots$

2.4 .2 Island Habitats $\ldots \ldots \ldots \ldots \ldots \ldots \ldots \ldots \ldots \ldots \ldots \ldots \ldots \ldots$

2.4 .3 Ringold Bluffs $\ldots \ldots \ldots \ldots \ldots \ldots \ldots \ldots \ldots \ldots \ldots \ldots . \ldots \ldots$

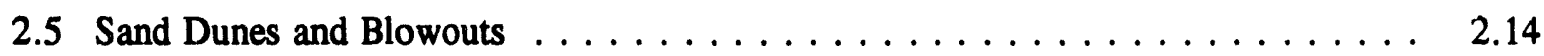

2.6 Abandoned Field Habitat and Other Disturbed Habitat Types $\ldots \ldots \ldots \ldots \ldots$

2.7 Shrub-Steppe Habitat on the Columbia River Plain . . . . . . . . . . 2.16

2.7.1 Shrubs/Sandberg's Bluegrass or Cheatgrass Habitat $\ldots \ldots \ldots \ldots \ldots \ldots$

2.7.2 Recovering Sagebrush Habitat on the Columbia River Plain . . . . . . . . 2.21

2.7.3 Hopsage and Greasewood Stands . . . . . . . . . . . . . . . 2.21

3.0 Important Wildlife Species on the Hanford Site $\ldots \ldots \ldots \ldots . \ldots \ldots$

3.1 Avian Species on the Hanford Site $\ldots \ldots \ldots \ldots \ldots \ldots \ldots \ldots \ldots \ldots$

3.1.1 Riparian/Riverine Avian Species . . . . . . . . . . . . . 3.3

3.1 .2 Raptor Species $\ldots \ldots \ldots \ldots \ldots \ldots \ldots \ldots \ldots \ldots \ldots$ 


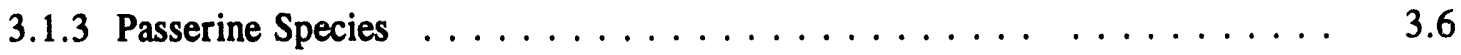

3.1 .4 Upland Game Birds $\ldots \ldots \ldots \ldots \ldots \ldots \ldots \ldots \ldots \ldots$

3.2 Mammalian Species $\ldots \ldots \ldots \ldots \ldots \ldots \ldots \ldots \ldots \ldots \ldots$

3.3 Reptiles and Amphibians $\ldots \ldots \ldots \ldots \ldots \ldots \ldots \ldots \ldots \ldots \ldots$

3.4 Terrestrial and Aquatic Invertebrates $\ldots \ldots \ldots \ldots \ldots \ldots \ldots \ldots$

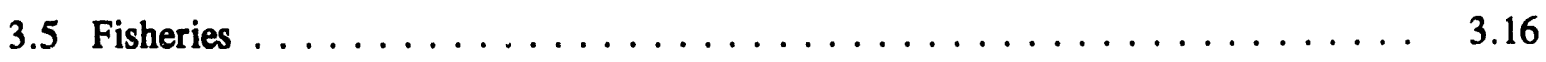

4.0 Plant Species of Concern $\ldots \ldots \ldots \ldots \ldots \ldots \ldots \ldots \ldots \ldots \ldots \ldots$

4.1 Riparian and Wetland Species $\ldots \ldots \ldots \ldots \ldots \ldots \ldots \ldots \ldots \ldots$

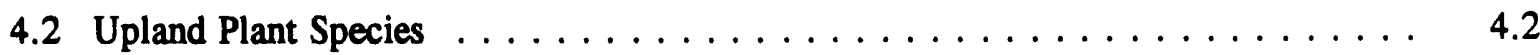

5.0 Pctential Areas of Sensitive or Critical Habitat $\ldots \ldots \ldots \ldots \ldots \ldots$

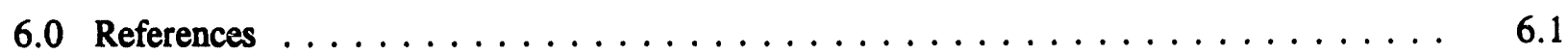

Appendix A - Locations of Selected Species of Concern on the Hanford Site . . . . . . . A.1 


\section{Figures}

1.1 Location and Major Features of the Hanford Site Within the Shrub-Steppe Ecoregion . . . . . . . . . . . . . . . . . . . . . . . . 1.3

2.1 Generalized Soils Map for the Hanford Site $\ldots \ldots \ldots \ldots \ldots \ldots$

2.2 Diagrammatic Representation of the Distribution of Hanford Site Habitats in Relation to Topographic Features . . . . . . . . . . . . . . . . 2.5

2.3 Distribution and Extent of Habitat Types Across the Hanford Site $\ldots \ldots \ldots \ldots$

2.4 Major Wetland Areas on the Hanford Site $\ldots \ldots \ldots \ldots \ldots \ldots \ldots \ldots$

2.5 Cheatgrass Abandoned Field and Disturbed Habitat Types on the Hanford Site $\ldots \ldots$. . 2.17

2.6 Percent Cover of Grasses on Undisturbed Habitats Near Basalt Waste Isolation Project Boreholes in $1989-1990 \ldots \ldots \ldots$. . . . . . . . . . . . . . . . 2.19

2.7 Density of Shrubs on Undisturbed Habitats Near Basalt Waste Isolation Project

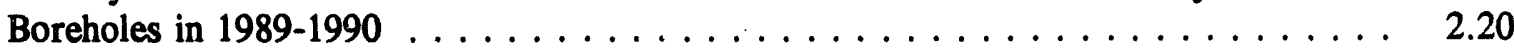

3.1 Major Fall Chinook Salmon Spawning Areas in the Hanford Reach

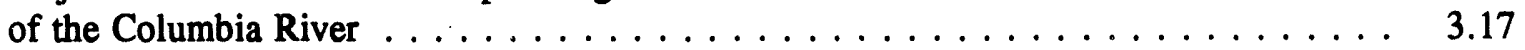

4.1 Locations of Plant Populations of Concern on the Hanford Site . . . . . . . . . . 4.3

A.1 Previously Recorded Loggerhead Shrike Nest Locations on the Hanford Site . . . . . A.1

A.2 Known Bald Eagle Roosting Sites on the Hanford Site $\ldots \ldots \ldots \ldots \ldots \ldots$. . . . .

A.3 Ferruginous Hawk Nest Locations on the Hanford Site $\ldots \ldots \ldots \ldots \ldots \ldots$

A.4 Swainson's Hawk Nest Locations on the Hanford Site, $1992 \ldots \ldots \ldots \ldots$. . . . . . A.4

A.5 Radiotelemetry Relocation Positions for Elk on the Hanford Site . . . . . . . . . . A.5 


\section{Tables}

1.1 References Summarizing Information on Hanford Site Wildlife, Plants,

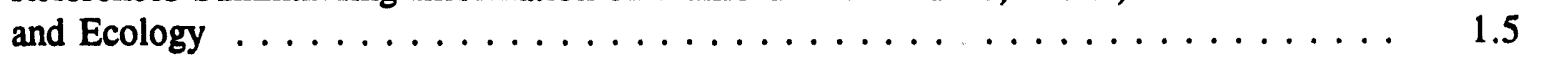

2.1 Islands of the Hanford Reach of the Columbia River Identified by Number

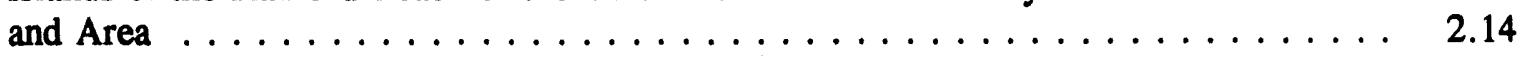

3.1 Threatened, Endangered, Candidate, and Monitor Birds on the Hanford Site . . . . . 3.2

3.2 Mammals Existing on the Hanford Site $\ldots \ldots \ldots \ldots \ldots \ldots \ldots$

3.3 Common Reptiles and Amphibians of Shrub-Steppe Habitats on the Hanford Site $\ldots \quad 3.14$

3.4 Relative Abundance of Insect Taxa Collected from Sagebrush, Rabbitbrush, and Hopsage $\ldots \ldots \ldots \ldots \ldots \ldots \ldots \ldots \ldots \ldots$

4.1 Status of Plant Species of Concern on the Hanford Site $\ldots \ldots \ldots \ldots . \ldots \ldots$ 


\subsection{Introduction}

Biological reviews, ecological risk assessments, environmental compliance activities, environmental restorations under the Comprehensive Environmental Response, Compensation, and Liability Act (CERCLA), and facility planning for the Hanford Site all require information concerning sensitive and critical habitats as well as piants and animal species of concern on the Site. Throughout the operational history of the Hanford Site, various research projects, monitoring programs, and educational endeavors have collected and compiled data concerning the plants and animals of the Site and their habitats. This report summarizes the collective knowledge to date on sensitive and critical habitats and species of concern in a comprehensive source document for use in environmental evaluations.

As part of the CERCLA characterization activities on the Site, both the Hanford Site Baseline Risk Assessment methodology (DOE 1993a) and the Columbia River Impact Evaluation Plan (DOE 1993b) call for a compilation of sensitive and critical habitat information. This information is to satisfy National Contingency Plan (40 CFR 300) requirements that a baseline risk assessment consider the threats to the environment, especially critical and sensitive habitats. Thus, the Environmental Engineering Function of Westinghouse Hanford Company (WHC) requested that Pacific Northwest Laboratory (PNL) ${ }^{(a)}$ compile pertinent information and produce this document.

Users of this document are cautioned that information on the distributions of some species is incomplete because surveys of all potential habitat have not been conducted (this is particularly true for the lands located north of the Columbia River where much less ecological study and biological survey work has been conducted). For example, a Hanford Site distribution map has been generated for loggerhead shrikes, but the data collected to date are largely the result of driving surveys conducted from roadways. Thus, the current version of this map could give the uninformed user a mistaken impression that loggerhead shrikes are distributed primarily along roadways. An incomplete distribution map for any species has the potential to be misused if the absence of a documented record for an organism from a given location is assumed to mean that it does not occur in that area. It could also mean that not all of the potential habitat has been surveyed or that species distributions have shifted since the completion of the map. Current unpublished data (W. H. Rickard, personal communication) suggests that nesting locations for at least two Hanford Site bird species [great blue herons (Andea herodias) and long-billed curlews (Numenius americanus)] have shifted in recent years. Thus, some consultation with knowledgeable Hanford Site biologists would be prudent to supplement this document during land-use planning and environmental restoration activities that have the potential to impact Hanford biota or their habitats.

(a) Pacific Northwest Laboratory is a multiprogram national laboratory operated for the U.S. Department of Energy by Battelle Memorial Institute under contract DE-AC06-76RLO 1830. 


\subsection{Site Description}

The habitat available or suitable for any particular species is a complex association of abiotic and biotic factors including the climate and microclimate; topography, slope, and aspect; soil type and depth; and associated vegetation. The Hanford Site (Figure 1.1) occupies a topographic lowland-the lower Columbia Basin-surrounded on the north, west, and south by basalt ridges. The Columbia River crosses the northern portion of the Site and flows alongside the eastern boundary of Hanford. Aquatic habitats associated with the river and permanent springs and streams are also products of the geology, soils, topography, vegetation, climate, and hydrology of watersheds. Generally, these watershed characteristics remain more stable than microhabitat characteristics in terrestrial environments. Distribution and abundance of terrestrial plants on the Hanford Site is determined in part by local landscape features such as topography, altitude, slope aspect and steepness, soil, surface water, and in some cases, groundwater. These same landscape features are important to wildlife, but the vegetative cover is especially important because it provides food, concealment, and protective cover, as well as nesting sites for some species of birds. Because vegetation is important to wildlife, habitats in this report are described in terms of dominant plant species. These are broad classifications of habitat type; it is important to realize that the vegetative cover of the Hanford Site has been altered by historical land-use practices such as livestock grazing, cultivation (irrigated and dryland agriculture), siting of nuclear-materials processing facilities, and waste disposal practices (Rickard et al. 1981; Rickard and Rogers 1983; Rickard and Watson 1985; Gray and Rickard 1989), as well as recurrent wildfires (Rickard and Poole 1989).

\subsection{Site Administration}

The majority of the Hanford Site (see Figure 1.1) is administered by the U.S. Department of Energy (DOE) for waste management, environmental restoration, and research and development. However, some portions of the Site are administered by other government agencies for wildlife management and recreation. The U.S. Fish and Wildlife Service, for example, manages the Saddle Mountain National Wildlife Refuge (NWR), which is located north of the Columbia River, from approximately river mile 374 west to the Site boundary and south of Highway 24 . The Washington State Department of Wildlife manages the remaining portions of the Hanford Site north and east of the Columbia River as the Wahluke State Wildlife Recreation Area (WRA). Pacific Northwest Laboratory administers the Arid Lands Ecology (ALE) Reserve on the western portion of the Hanford Site for DOE.

In addition, in the central portion of the Hanford Site, the state of Washington has leased approximately 0.15 square miles between the 200-West and 200-East Areas, and owns 1 square mile approximately 4 miles south of the 200-East Area and 5 miles west of the Wye Barricade. Also, the Washington Public Power Supply System manages approximately 3 square miles on the eastern portion of the Hanford Site, just south of the major sand dune fields.

The islands in the Columbia River are administered by a number of government agercies, including the Washington State Department of Natural Resources, the U.S. Bureau of Land Management, the U.S. Army Corps of Engineers, the U.S. Fish and Wildlife Service, and the City of Richland, Washington. The National Park Service has recommended that the Columbia River from 


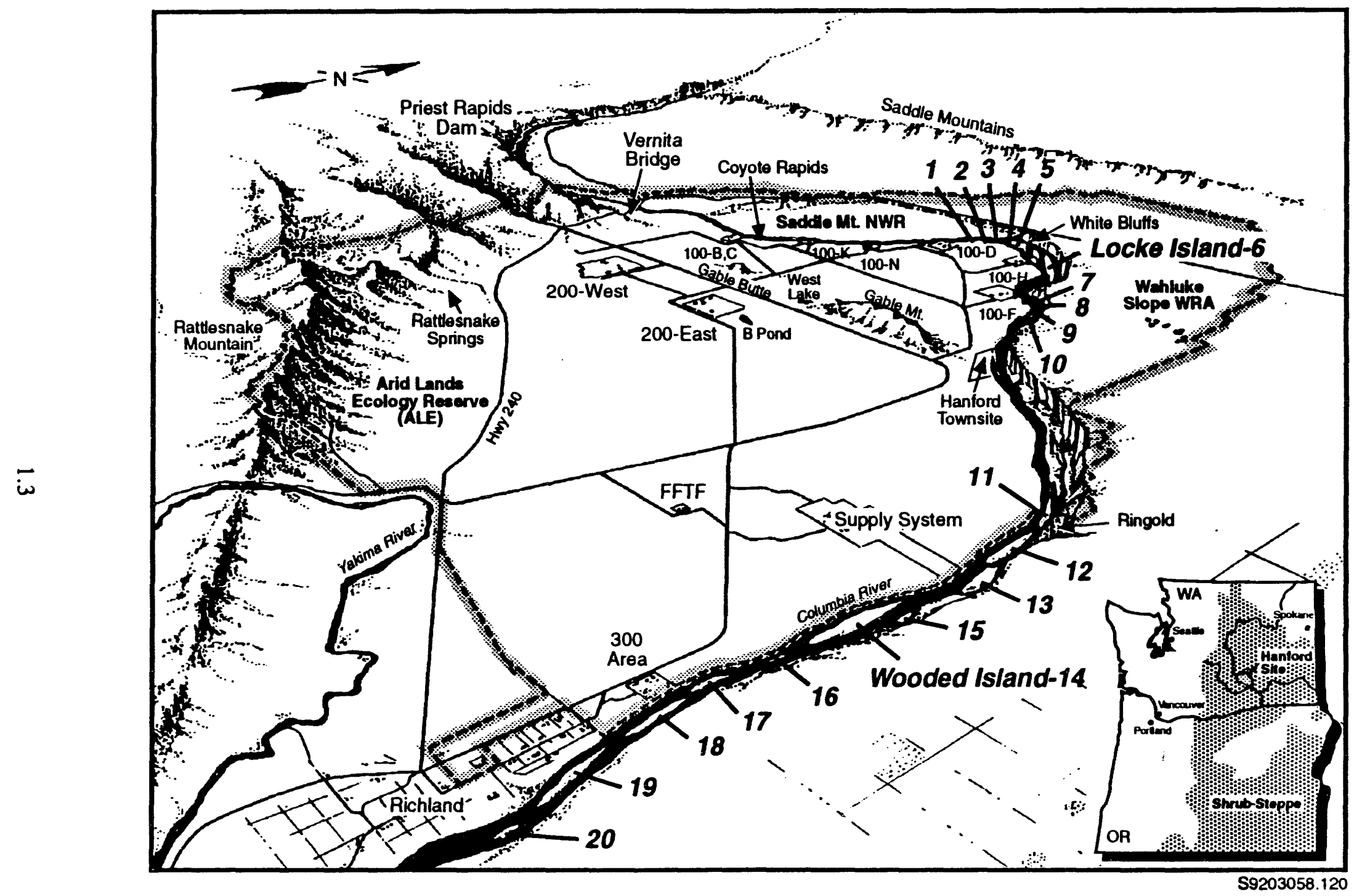

Figure 1.1. Location and Major Features of the Hanford Site Within the Shrub-Steppe Ecoregion 
river mile 396 to river mile 346.5 , all publicly owned land within 1/4 mile of the shoreline, and all lands currently part of the Saddle Mountain NWR and Wahluke State WRA be designated as a new national wildlife refuge with a Wild and Scenic River overlay to be administered by the U.S. Fish and Wildlife Service. This designation requires legislative action by Congress, which has not occurred at this time.

This report describes the general features of the vegetation mosaic of the Hanford Site and wildlife associated with these primary habitats. Particular attention is given to the area west of the Columbia River (Section 2.0), where most of the industrial facilities associated with the Hanford Site are located and most historical agricultural and urban development occurred. Sensitive, threatened, and endangered wildlife and plant species are given special consideration as well as those species recognized as important for their ecological, recreational, aesthetic, or commercial values (Sections 3.0 and 4.0). Appendix A contains maps of known locations of selected species of concern. Plant and wildlife species that may be of special significance to Native Americans are not addressed.

Other recent literature summarizing information on Hanford Site ecology and plaiit and wildlife species of concern are listed in Table 1.1. Another resource for current information and maps on these topics is the database maintained for the Hanford Site Wildlife Resources Monitoring Project managed through PNL's Terrestrial Ecology Group, Earth and Environmental Sciences Center. A database developed and maintained through this project and other funding to include historical and current information on Hanford Site plants and animals. 
Table 1.1. References Summarizing Information on Hanford Site Wildlife, Plants, and Ecology ${ }^{(a)}$

Reference

Cushing, C. E. (ed). 1992

Daubenmire, R. 1970

Energy Research and Development Administration. 1975

Fickeisen, D. H., D. D. Dauble, D. A. Neitzel, W. H. Rickard, R. L. Skaggs, and J. L. Warren. 1980a

Fickeisen, D. H., R. E. Fitzner, R. H. Sauer, and J. L. Warren. 1980b

Fitzner, R. E., and R. H. Gray. 1991

Fitzner, R. E., S. G. Weiss, and J. A. Stegen. 1992

Gray, R. H., and D. D. Dauble. 1977

Gray, R. H., and W. H. Rickard. 1989

Landeen, D. S., A. R. Johnson, and R. M. Mitchell. 1992

Rickard, W. H., and D. A. Watson. 1985

Rickard, W. H., L. E. Rogers, B. E. Vaughan, and S. F. Liebetrau. 1988

Rickard, W. H., R. E. Fitzner, and C. E. Cushing. 1981

Rogers, L. E., and W. H. Rickard. 1977

Sackschewsky, M. R., D. S. Landeen, G. I. Baird, W. H. Rickard, and J. L. Downs. 1992

Stegen, J. A. 1992

Weiss, S. G., and R. M. Mitchell. 1992

Wolf, E. G. 1976
Title

Hanford Site National Environmental Policy Act (NEPA) Characterization

Steppe Vegetation of Washington

Final Environmental Statement, Waste Management Operations

Aquatic and Riparian Resource Study of the Hanford Reach, Columbia River, Washington

Wildlife Usage, Threatened and Endangered Species and Habitat Studies of the Hanford Reach, Columbia River, Washington

The Status, Distribution and Ecology of Wildlife on the U.S. DOE Hanford Site: A Historical Overview of Research Activities

Biological Assessment for Threatened and Endangered Wildlife Species Related to CERCLA Characterization Activities

Checklist and Relative Abundance of Fish Species from the Hanford Reach of the Columbia River

The Protected Area of Hanford as a Refugium for Native Plants and Animals

Status of Birds at the Hanford Site in Southeastern Washington

Four Decades of Environmental Change and Their Influence Upon Native Wildlife and Fish on the MidColumbia River, Washington, U.S.A.

Shrub-Steppe: Balance and Change in a Semi-Arid Terrestrial Ecosystem

Biological Colonization of an Industrial Pond

Ecology of the 200 Area Plateau Waste Management Environs: A Status Report

Vascular Plants of the Hanford Site

Biological Assessment for State Candidate and Monitor Wildlife Species Related to CERCLA

A Synthesis of Ecological Data from the 100 Areas of the Hanford Site

Characterization of the Benthos Community. In Final Report on Aquatic Ecological Studies Conducted at the Hanford Generating Project

(a) Complete reference listings can be found in Section 6.0 of this document. 


\subsection{Shrub-Steppe Habitats on the Hanford Site}

The Hanford Site lies within the broad semi-arid shrub-steppe ecoregion: which includes much of eastern Oregon and southeastern Washington. At Hanford, the climate is characterized as having hot, dry summers and cold winters. Most of the effective precipitation falls between October and April, and precipitation increases with the elevation gradient (Thorp and Hinds 197?). The highest elevation on the Hanford Site is on the crest of Rattlesnake Mountain $(1150 \mathrm{~m})$, which receives approximately 30 to $35 \mathrm{~cm}$ of precipitation annually. This northeast-facing anticlinal ridge falls steeply to about $500 \mathrm{~m}$ elevation, where slopes become more moderate ( 20 to $25 \mathrm{~cm}$ of precipitation). The topography continues to descend to approximately $150 \mathrm{~m}$ in Cold Creek Valley and eastward to the Columbia River, where annual average precipitation is $12 \mathrm{~cm}$ (Rickard et al. 1988). The 200 Area Plateau rises above the surrounding area, with Gable Butte and Gable Mountain rising fairly steeply to $230 \mathrm{~m}$ and $340 \mathrm{~m}$, respectively. Soils range from silt loams on the slopes of Rattlesnake Ridge and Gable Mountain to sandy loams, loamy sands, and sands on the Columbia River Plain (Hajek 1966) (Figure 2.1).

For the purposes of this document, habitat types on the Hanford Site are grouped as habitats occurring on slopes and habitats occurring on the Columbia River Plain, as shown in Figure 2.2:

\section{Slope Habitats}

- basalt outcrops, scarps and screes

- riparian along streams and springs

- sagebrush/bunchgrass

\section{Columbia River Plain Habitats}

- sand dunes and blowouts

- abandoned fields

- riverine/riparian along the Columbia River

- shrub-steppe

Figure $2.3^{(a)}$ delineates the distribution and extent of habitat types across the Hanford Site. This map was developed using aerial photography from flights in 1987 and 1992.1992 photographs were made available through the Benton County Land Use Planning Office and, thus, only included the portion of the Hanford Site that falls within the Benton County boundaries. Although results of field assessments have been included to refine the map, a complete validation effort has not been conducted. The community of potential users of this information must be cautious in applying these maps without ground surveys of the land under consideration. Natural disturbances such as wildfires

(a) For information on the availability of digital or hard copy of the Hanford Site habitat types, contact the Wildlife Resources Monitoring Project Manager, Terrestrial Ecology Group, Earth and Environmental Sciences Center, Pacific Northwest Laboratory, P.O. Box 999, Richland, Washington, 99352. 
or human-related disturbances from construction/operations activities can alter the available habitat at any time. These maps are only an interpretation of the aerial photography that was taken during 1987 and 1992 and do not attempt to reflect changes in habitat since that time. For example, possible habitat changes resulting from wildfires that occurred on the northern part of the Hanford Site in 1993 are not included in the vegetative cover maps in this document.

The following sections describe èach of the habitat types and provide brief discussions of the wildlife associated with each habitat type. The descriptions of abandoned field vegetation habitats that occur on the slopes of the Rattlesnake Hills are included in the section describing abandoned and disturbed habitats on the Columbia River Plain. More detailed information on wildlife and habitat preferences is given in Section 3.0. Section 4.0 presents information on plant species of concern that occur on or near the Hanford Site.

\subsection{Basalt Outcrops, Scarps, and Screes}

Basalt outcrops, scarps (cliffs), and screes (loose rock at the base of cliffs or on slopes) occupy relatively little area on the Hanford Site, but are found along the crests and slopes of the Rattlesnake Hills, Yakima Ridge, Umtanum Ridge, Saddle Mountains, Gable Mountain, and Gable Butte. The most extensive scarp and scree areas occur on Umtanum Ridge overlooking the Columbia River downstream from Priest Rapids Dam. Scarps and screes are nearly devoid of vascular plants, but outcrops support some plants that do not grow elsewhere on the Hanford Site.

Scree slopes on the Site are most often north- to northeast-facing slopes and often develop small islands of more stabilized substrate with a veneer of soil. These islands of soil may support squaw currant (Ribes cereus), bluebunch wheatgrass (Agropyron spicatum or Pseudoroegneria spicata), Sandberg's bluegrass (Poa sandbergii), and forbs in early spring months when moisture is abundant. Scree slopes that are south-facing, such as those on Gable Mountain's south side, support little vegetation. The Washington State threatened plant species, Hoover's desert parsley (Lomatium tuberosum), is confined to steep scree slopes with known populations on Umtanum Ridge on the scree slopes facing the Columbia River.

Rock outcrops support scattered individuals of short-statured shrubs and grasses, especially rock buckwheat (Eriogonum sphaerocephalum), and/or thyme buckwheat ( $E$. thymoides), growing in association with Sandberg's bluegrass. Higher elevations, such as those found on Rattlesnake Mountain, generally support greater plant diversity than lower elevations. Characteristic highelevation species are rosy balsamroot (Balsamorhiza rosea), Columbia goldenweed (Haplopappus stenophyllus), Hood's phlox (Phlox hoodii), dagger pod (Phoenicaulis cheiranthoides), and others. Rigid sagebrush (Artemisia rigida) is known to grow only on the western end of Gable Mountain and on Umtanum Ridge on the Hanford Site; it is apparently absent from the Rattlesnake Hills and Yakima Ridge. 


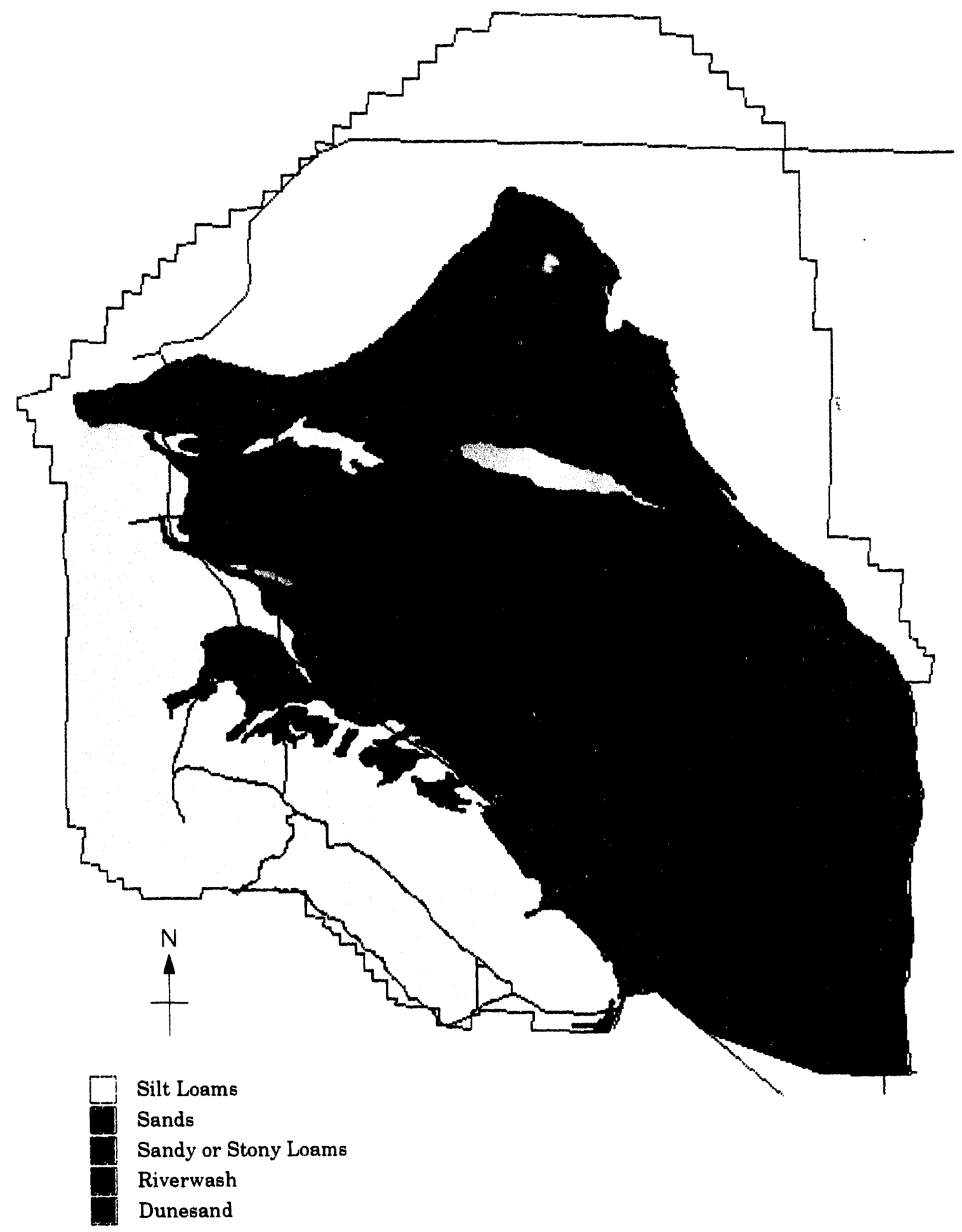

Figure 2.1. Generalized Soils Map for the Hanford Site [Reclassified from Hajek (1966)] 


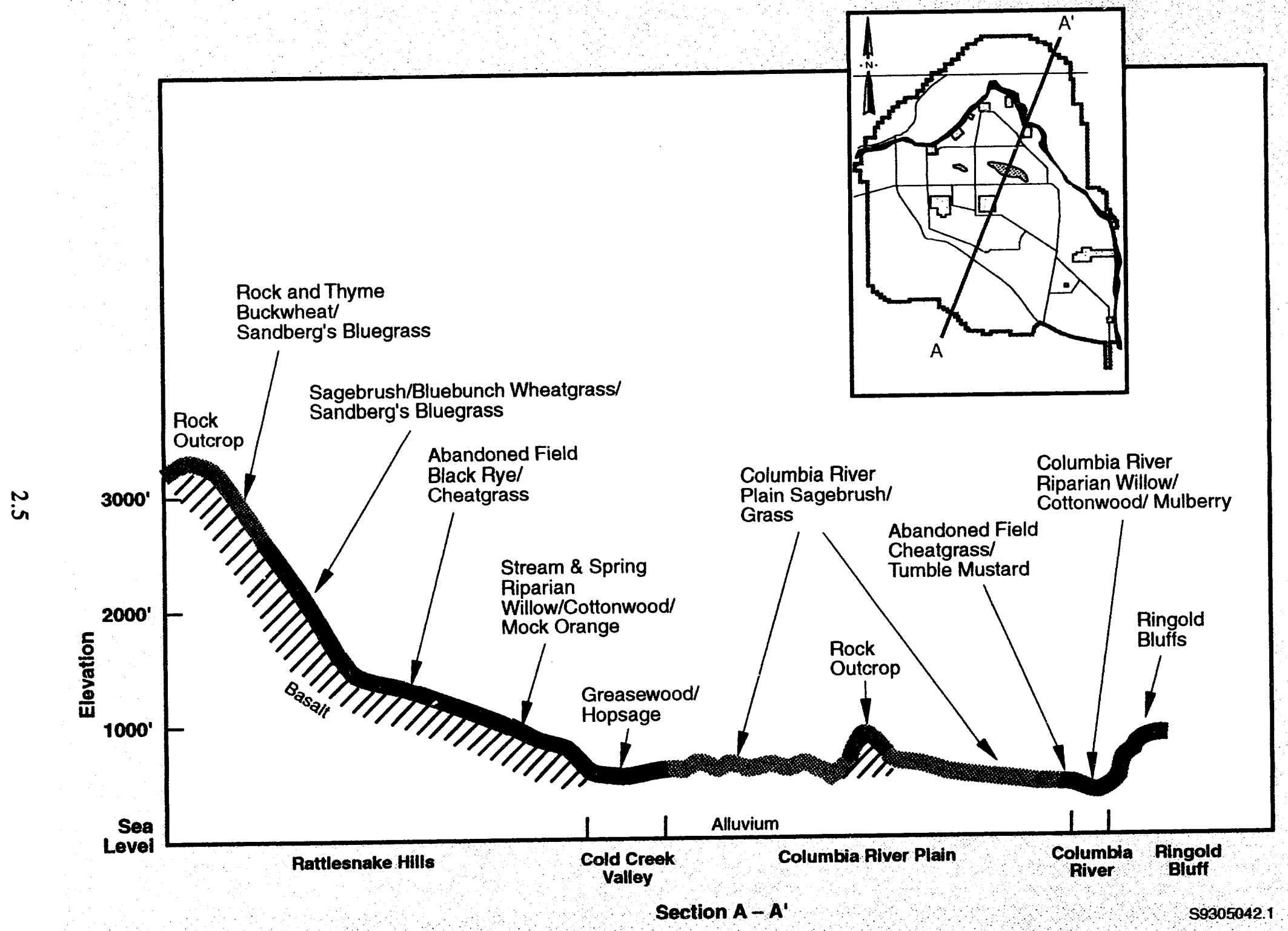

Figure 2.2. Diagrammatic Representation of the Distribution of Hanford Site Habitats in Relation to Topographic Features 


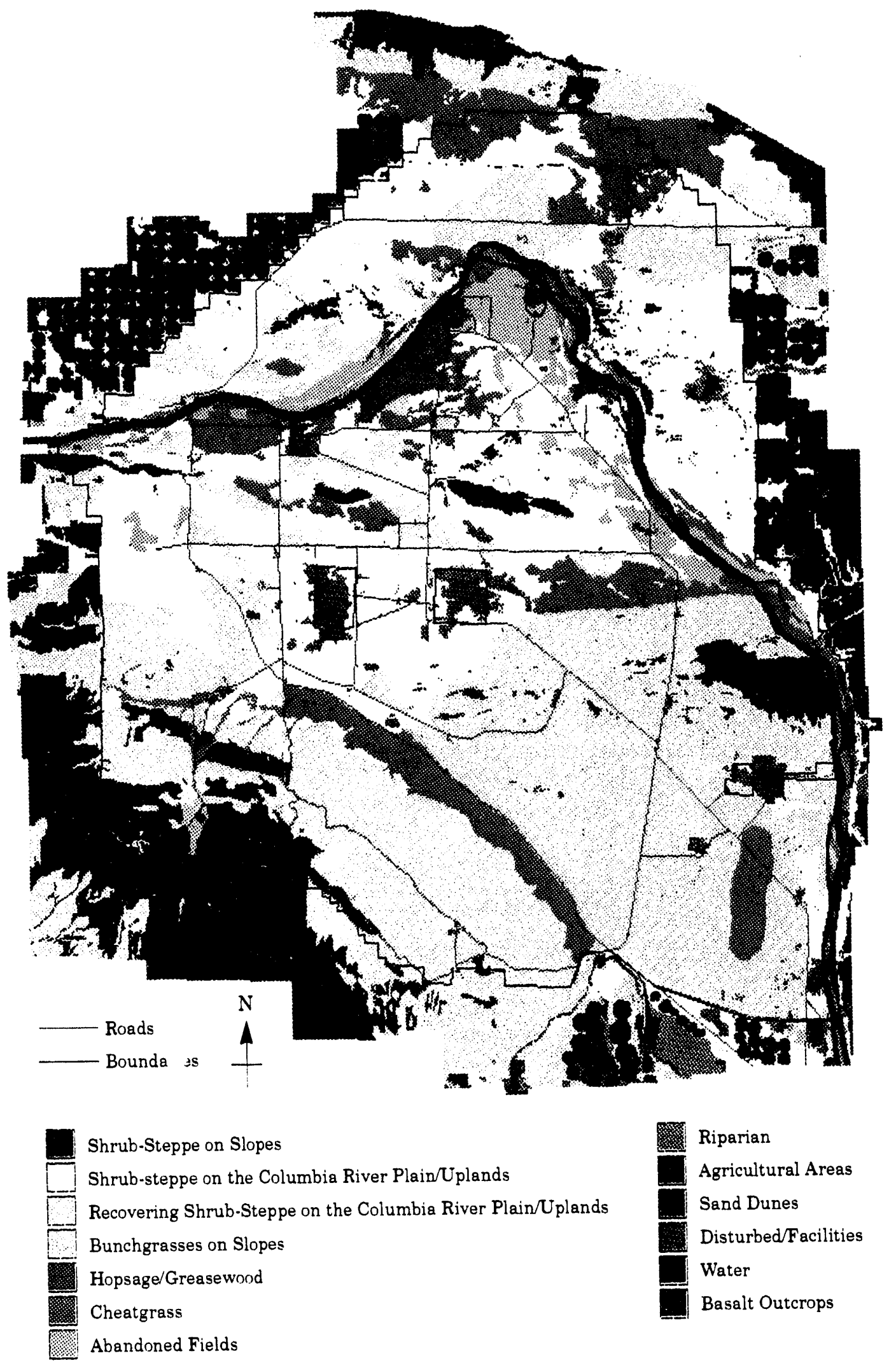

1 November 1993. Revision 0: based on 1987 and 1991 aerial photography: Map subject to revision as additional survey data become available and as cover types change in response to natura! and human-caused events.

Figure 2.3. Distribution and Extent of Habitat Types Across the Hanford Site (Preliminary map from 1987 and 1991 aerial photography) 
Scarps provide nesting sites for prairie falcons (Falco mexicanus) especial ' on Umtanum Ridge, the Rattlesnake Hills, and Gable Butte, where falcons regularly nest. Scarps have historically provided nesting sites for ferruginous hawks (Bueto regalis), but in recent years most of these birds have elected to nest on steel transmission line towers located on the Columbia River Plain (Fitzner and Newell 1989).

Rock wrens (Salpinctes obsoletus) are the characteristic nesting birds in scarps and scree habitats on Gable Mountain, Gable Butte, the Rattlesnake Hills, Yakima Ridge, and Umtanum Ridge. The steep slopes of these same ridges that support bluebunch wheatgrass also support nesting populations of chukars (Alectoris chukar). Rock outcrops are apparently the preferred nesting sites of poorwills (Phalaenoptilus nuttallii) (Lundstrom 1988).

Only a few species of mammals regularly reside on rock outcrops, scarps, and screes. These include the yellow-bellied marmot (Marmota flaviventris) and wood rat (Neotoma cinereus). Scarps and screes provide hibernacula for rattlesnakes (Crotalus viridis) and gopher snakes (Pituophis melanoleucus). Horned lizards (Phrynosoma douglasii) inhabit outcrops at elevations as high as $1050 \mathrm{~m}$.

\subsection{Riparian Habitats Along Streams and Springs}

Small springs and streams, some permanent and others intermittent, are widely spaced across the slopes of the Rattlesnake Hills. Most of these waterways are characteristically dominated by narrow corridors of deciduous trees and shrubs (Daubenmire 1970). The stream with the greatest flow volume is Snively Creek, where a permanent stream flows for about $2 \mathrm{~km}$ along the canyon. Rattlesnake Springs arises in the bed of Dry Creek at the base of the east end of Yakima Ridge. The riparian zones associated with Rattlesnake Springs and Snively Creek (see Figure 2.3) support highly diverse biologic communities (Cushing and Wolf 1984). Peachleaf willow trees (Salix amgdaloides) dominate the riparian corridor at Rattlesnake Springs, but black cottonwoods (Populus trichocarpa) and shrub willows along with mock orange (Philadelphis lewisii) are dominants at Snively Creek. Other shrubby species that occur are chokecherry (Prunus virginiana), service berry (Amelanchier alnifolia), golden currant (Ribes aureum), wild rose (Rosa woodsii), red-osier dogwood (Cornus stolonifera), and blue elderberry (Sambucus cerulea). Watercress (Rorippa nasturtium aquaticum) grows abundantly in the swift spring streams until flash floods decimate populations in the winter and early spring. Other vegetation includes bulrush (Scirpus spp.), spike rush (Eleocharis spp.), and cattail (Typha latifolia).

Within the arid portion of the Hanford Site, these springs provide drinking water for terrestrial vertebrates such as mule deer, elk, and chukar (Cushing 1992) and important cover and forage for mule deer (Odocoileus hemionus) and elk (Cervus elaphus) that inhabit the Rattlesnake Hills. Riparian trees and shrubs provide nesting habitat for a number of bird species that do not nest in the surrounding shrub-steppe habitat (Rotenberry et al. 1979). In winter months, this habitat provides food and cover for flocks of chukar partridges, dark-eyed junco (Junco hyemalis), white-crown sparrows (Zonotrichia leucophrys), American robin (Turdus migratorius), and other species. Although the total area occupied by riparian habitats is very small, the species diversity there is greater than in the surrounding shrub-steppe habitat. 


\subsection{Sagebrush/Bunchgrass Habitats}

The slopes of the Rattlesnake Hills support both shrub-steppe and native bunchgrass associations. The floristic composition of the vegetation changes as elevation increases (Thorp and Hinds 1977). This change is related to increasing precipitation and decreasing air and soil temperatures. The lower-elevation, gentle slopes of the Rattlesnake Hills, Yakima Ridge, and Umtanum Ridge support stands characteristic of the big sagebrush/Sandberg's bluegrass (Artemisia tridentata/Poa sandbergii) association as described by Daubenmire (1970). In some places, cheatgrass (Bromus tectorum) has replaced native grasses as the dominant understory species. Cheatgrass is an alien annual grass that was introduced to this region in the late 1800s and early 1900s (Mack and Pyke 1983).

As elevation increases, bluebunch wheatgrass replaces Sandberg's bluegrass as the dominant understory species. Cusick's bluegrass (Poa cusickii) and hawk's beard (Crepis atrabarba) become more abundant in the understory. At the highest elevation, three-tip sagebrush (Artemisia tripartita) replaces big sagebrush as the dominant shrub. Bluebunch wheatgrass and Sandberg's bluegrass are still important members of the understory, but Idaho fescue (Festuca idahoensis) becomes more abundant as well.

Wildfires that occurred in 1981 and 1984 burned much of the sagebrush from the Rattlesnake Hills. Big sagebrush does not regenerate from rc ststock after burning. Thus, portions of the original sagebrush/bunchgrass habitat on Hanford support only the native bunchgrasses resulting in large tracts where a bluebunch wheatgrass/Sandberg's bluegrass association persists. The natural re-establishment of big sagebrush across the landscape through seed dispersal and germination likely will require many years.

Horned larks (Eremephila alpestris) and meadowlarks (Sturnella neglecta) are the most abundant breeding birds in these sagebrush-bunchgrass habitats. Vesper sparrows (Pooectes gramineus) and chukar are also common. Historically, sagebrush-bunchgrass habitat has provided nesting sites for sage grouse (Centrocercus urophasianus). This species has disappeared as a regular breeding bird from the Hanford Site in recent years partly as a result of the removal of big sagebrush by wildfire, however, sage grouse are present on adjacent private land and on the nearby Yakima Training Center operated by the U.S. Army.

\subsection{Riverine/Riparian Habitat Along the Columbia River}

The Columbia River is the dominant aquatic ecosystem on the Hanford Site and supports a diverse community of plankton, benthic invertebrates, fish, and other biota. It is the fifth largest river in North America. The river is dammed both upstream and downstream from the Hanford Site, and the reach flowing through the area is the last free-flowing, but regulated, reach of the Columbia River in the United States. As natural riverine habitat has been reduced or altered throughout the Columbia Basin, species dependent on this habitat have been eliminated or forced into less desirable areas. As a result, the Hanford Reach is the only portion of the Columbia River that supports breeding populations of fish that evolved in the free-flowing aquatic ecosystem of the Columbia River. The varied fish populations within the Reach are directly attributable to the unique and diversified riverine ecosystem. The river channel within the Reach is braided around islands, 
submerged rock ledges, and gravel bars, which causes pooling and channeling and creates a complex network of unique habitat features.

The unimpounded Hanford Reach has experienced less alteration than other reaches of the Mid-Columbia portion of the river, and unlike other reaches, peak flows associated with winter rains or spring runoff still influence upland, riparian, and riverine vegetation along the approximately $80 \mathrm{~km}$ of shoreline. Riverine habitat includes the sloughs, backwaters, wetted shorelines, islands, and riparian trees that are associated with the river flood plain and covered by water for the majority of the year. Riparian habitat includes the shoreline-river interface where species that are tolerant of fluctuating surface-water elevations persist. Woody plants are scarce on the Hanford Site, but the shorelines of the Columbia River support a thin band of trees and shrubs, mostly willows (Salix spp.). The exotic woody species present include mulberry (Morus alba), Siberian elm (Ulmus pumilla), and Russian Olive (Eleagnus angustifolia). Wormwood or mugwort (Artemesia campestris, Artemesia lindleyana), sedges (Carex and Eleocharis spp.), reed canarygrass (Phalaris arundinacea), and bulbous bluegrass (Poa bulbosa) are a few of the herbaceous species that occur along the shoreline.

For a variety of wildlife species, riverine and riparian habitants are seasonally important, and provide nesting and foraging opportunities, and thermal and travel cover (Books 1984). Willow thickets trap food for waterfowl (e.g., Canada geese, Branta canadensis) and shorebirds (e.g., killdeer, Charadrius vociferus, spotted sandpiper, Actitis macularia, etc.) and provide nesting habitat for a number of bird species. Terrestrial and aquatic insects are abundant in emergent grasses and provide forage for fish, waterfowl, and shorebirds. Beaver (Castor canadensis) and muskrats (Ondatra zibethica) rely on shoreline habitat for foraging and denning materials. Mink (Mustela vison), raccoon (Procyon lotor), bald eagles (Haliaeetus leucocepinalus), and osprey (Pandion haliaetus) feed on fish, especially spawned salmon, along the Reach. Mule deer (Odocoileus hemionus) forage on the leaves and twigs of mulberry trees and other browse plants during the summer months. Planted trees, mostly black locust (Robinia pseudo-acacia), Siberian elm, and white poplar (Populus albus) located near the shoreline are used as night roosts and as daytime perches by bald eagles in winter (Eisner 1991). Some shoreline trees are used as nesting sites by great blue herons (Ardea herodias), black-billed magpies (Pica pica), northern orioles (Icterus galbula), and raptors such as Swainson's hawks (Buteo swainsoni), red-tailed hawks (Buteo jamaicensis), and great horned owls (Bubo virginianus).

\subsubsection{Emergent Habitats and Wetlands}

Although the Columbia River is not impounded by a dam as it flows through the Hanford Site, its flow is regulated by water releases at a series of upriver dams. Emergent vegetation occurs within the riverine area (e.g., that area below mean high water) of the Hanford Reach that also includes riffles, gravel bars, oxbow ponds, backwater sloughs and the cobble shorelines that typified the Columbia River before inundation by dam development. These emergent habitats, which occur infrequently along the Hanford Reach, have acquired ecological significance because of a net loss of riverine wetland habitat elsewhere within the Mid-Columbia River region. Emergent species include reed canarygrass, common witchgrass (Panicum capillare), and large barnyard grass (Echinochloa crusgalli). The artificially regulated water level has encouraged the growth of mulberry trees and reed canarygrass along the shoreline at the expense of other riparian zone species. However, permanent vegetation plots have not been established to document the magnitude or the rate of change 
in the vegetation. The Washington State endangered plant species persistent sepal yellowcress, or Columbia yellowcress (Rorippa columbiae), grows at scattered locations along the wet shoreline of the Columbia River (Sauer and Leder 1985). However, all populations of yellowcress have not been located or mapped, and little is known about this species' response to regulated water-level fluctuations.

Within the Columbia River, diatoms represent $90 \%$ of the algae in the Hanford Reach. Species composition of plankton that persists within the reach is influenced by communities in upstream reservoirs (e.g., Priest Rapids). Phytoplankton and zooplankton populations at Hanford are transient, flowing from one reservoir to another, so that characteristic endemic groups of plankton do not develop in the Hanford Reach. Although populations are largely transient, the peak concentration of phytoplankton develops in April and May (Cushing 1992). Phytoplankton (free-floating algae) and periphyton (sessile algae) are abundant and provide food for herbivores such as immature insects and molluscs, which in turn, are consumed by carnivorous species (Cushing 1992).

Because currents within the main channel of the Hanford Reach are generally strong, macrophytes that include Lemna, Potamogeton, Elodea, and Myriophyllum are generally limited. Rushes (Juncus spp.) and sedges exist on the shorelines of several sloughs along the Reach at White Bluffs, below the 100-H Area, downstream of the 100-F Area, and along the Hanford Slough (Cushing 1992). The release of water used in industrial processes at the Hanford facilities created several artificial ponds that also provide aquatic habitat. These ponds are ephemeral but have contributed to the establishment of cattail, reed canarygrass, willow, cottonwood, and Russian olive.

There have been no formal wetlands delineations performed over most of the Hanford Site, although many locations qualify for this designation. Within the Columbia River Plain south of the Columbia River, natural wetlands occur at Rattlesnake Springs and at West Lake; artificial wetlands in the form of ponds and ditches have been created as a result of waste management activities near the 200 Areas. A thin strip of wetland vegetation also occurs along most of the shoreline of the Columbia River and on islands in the river. Larger wetland areas along the Columbia River are found near the 100-B Area, 100-K Area, and the sloughs near 100-H and 100-F Areas, the Hanford Townsite, and Savage Island (Figure 2.4). On the Wahluke Slope, large wetland areas, and several lakes have been created by irrigation runoff.

\subsubsection{Island Habitats}

Islands, accounting for $64.2 \mathrm{~km}$ of island shoreline (U.S. Army Corps of Engineers 1976), are located within the main channel of the Hanford Reach. These islands range in size from 1 to $8 \mathrm{~km}$ in length and from 2.7 to 135 ha in area (Table 2.1 and Figure 1.1). Islands provide resting, nesting, and escape habitat for waterfowl, shorebirds, small mammals, and mule deer. Shoreline riparian vegetation that characterizes the islands includes willow, poplar, Russian olive, and mulberry. Species occurring within the island interior include buckwheat, lupine (Lupinus spp.), mugwort (Artemisia lindleyana), thickspike wheatgrass (Agropyron dasystachyum), giant wildrye (Elymus giganteus), yarrow (Achillea millefolium), and cheatgrass. 


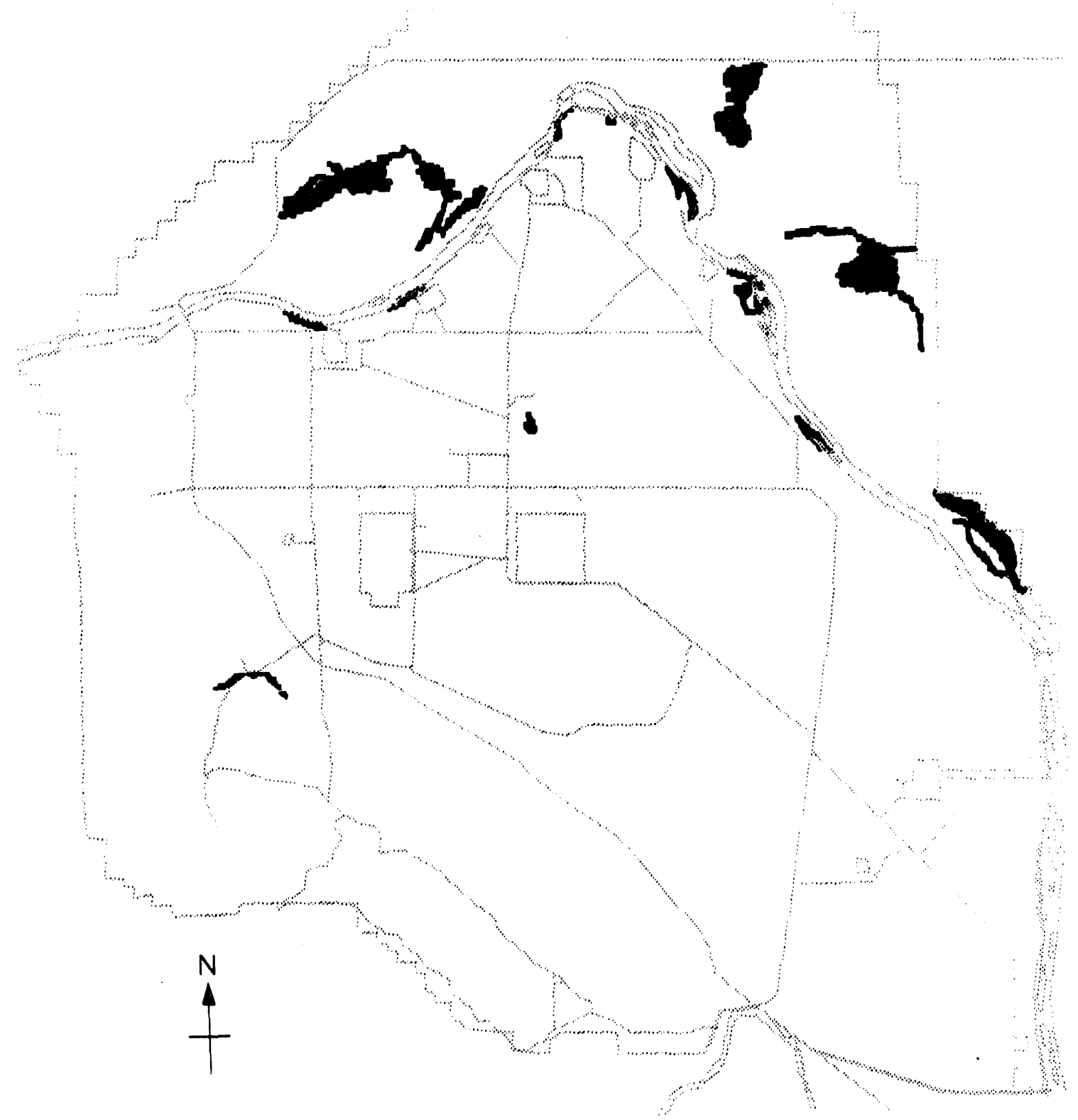

Wetland Areas

Iigure 2.4. Major Wetland Areas on the Hanford Site 
Table 2.1. Islands of the Hanford Reach of the Columbia River Identified by Number and Area

\begin{tabular}{|c|c|c|c|c|c|c|c|}
\hline $\begin{array}{l}\text { Island } \\
\text { No. } \\
\end{array}$ & $\frac{\text { Area }}{(\text { ha) (a) }}$ & $\begin{array}{l}\text { Approximate } \\
\text { Rivermile } \\
\end{array}$ & $\frac{\text { Administrator }}{!}$ & $\begin{array}{l}\text { Island } \\
\text { No. } \\
\end{array}$ & $\frac{\text { Area }}{(\text { has) }}$ & $\begin{array}{l}\text { Approximate } \\
\text { Rivermile } \\
\end{array}$ & Administrator ${ }^{(b)}$ \\
\hline 1 & 11.1 & 376 & DNR & 12 & 58.3 & 354 & Mixed \\
\hline 2 & 14.5 & 375 & BLM & 13 & 80.1 & 353 & Mixed \\
\hline 3 & 82.4 & 374 & BLM & 14 & 121.4 & 351 & DOE/DNR \\
\hline 4 & 4.6 & 373 & DNR & 15 & 20.6 & 351 & $\mathrm{ACOE}$ \\
\hline 5 & 4.5 & 373 & DNR & 16 & 6.5 & 347 & DNR \\
\hline 6 & 144.6 & 372 & DOE/DNR & 17 & 37.7 & 346 & Mixed \\
\hline 7 & 5.9 & 369 & DNR & 18 & 38.0 & 344 & Mixed \\
\hline 8 & 29.2 & 368 & DOE & 19 & 49.2 & 341 & Mixed/Richland \\
\hline 9 & 19.3 & 367 & BLM & 20 & 14.7 & 339 & Mixed/Richland \\
\hline 10 & 8.8 & 366 & DNR & 21 & 12.8 & 338 & Mixed \\
\hline 11 & 22.8 & 356 & BLM & & & & \\
\hline
\end{tabular}

(a) Island area is based on September 1991 aerial photography except for islands 19, 20, and 21, which are based on the 1992 U.S. Geological Survey 7.5-minute quadrangle Richland, Washington map.

(b) DNR = Washington Department of Natural Resources; BLM = U.S. Bureau of Land Management; $\mathrm{DOE}=$ U.S. Department of Energy; ACOE = Army Corps of Engineers; Mixed = Administered islands, non-DOE ownod; Mixed/Richland = Mixed/City of Richland, Washington.

\subsubsection{Ringold Bluffs}

The Ringold Bluffs (White Bluffs) occur along the eastern shore of the Columbia River. The steepest parts of the bluffs are eroding into the Columbia River and are essentially devoid of vascular vegetation. Nevertheless, the steep bluffs provide nesting habitats for thousands of cliff swallows (Petrochelidon pyrrhonota) that plaster their mud nests on the vertical walls, especially where the dwellings are protected from the sun and weather by overhanging ledges. Ledges and cracks in the bluffs are used as nesting sites by red-tailed hawks, common ravens (Corvus corax), rock doves (Columbia livia), and a few pair of Canada geese.

The less steep portions of the bluffs support vascular plants, especially stands of spiny hopsage (Grayia spinosa). Groundwater seeps in the bluffs support patches of willows and other riparian species, such as reed canarygrass, cattails, and bulrush.

\subsection{Sand Dunes and Blowouts}

Sand dunes and blowouts are difficult substrates for plants to colonize. Established dunes occur in a large area on the western side of the Columbia between the Washington Public Power Supply System plants and the abandoned townsite of Hanford (see Figures 1.1 and 2.3). Blowouts occur in scattered places in a broad band across the Columbia River Plain from Highway 240 extending eastward to the sand dunes. 
The most successful dune-stabilizing plants are rhizomatous perennials, especially pale evening primrose (Oenothera pallida), sand dock (Rumex venosus), and thickspike wheatgrass. Other deeprooted species associated with deep, sandy soils are scurfpea (Psoralea lanceolata), turpentine spring parsley (Cymopterus terebinthus), and bitterbrush (Purshia tridentata). Big sagebrush also grows in sandy soil and to a relatively large size (1 to $2 \mathrm{~m})$. Other species often associated with sandy soils are cheatgrass, Indian ricegrass (Oryzopsis hymenoides), and needle-and-thread grass (Stipa comata). The Washington State sensitive plant species gray cryptantha (Cryptantha leucophaea) grows in scattered locations on sandy soils on the Columbia River Plain.

Bitterbrush is regarded as an important winter browse species for mule deer and, in recent years, wildfires on the Hanford Site decimated bitterbrush stands all across the southern portion of the Columbia River Plain (particuiarly a fire in 1984). The impact of the loss of this forage resource on Hanford's resident mule deer herd is unknown in the absence of numeric population and health data on mule deer before the fire. Tall, dense bitterbrush and sagebrush shrubs are the preferred nesting habitats of the Washington State candidate species the loggerhead shrike (Lanius ludovicianus) (Poole 1992).

\subsection{Abandoned Field Habitat and Other Disturbed Habitat Types}

Abandoned cultivated fields are present along the western and eastern banks of the Columbia River, along the Cold Creek Valley, and in the Snively Basin on the ALE Reserve. The most extensive patches of old-field habitat are located along the Columbia River (Figure 2.5). Farming ceased in 1943 when the land was acquired for siting of nuclear-materials production facilities. Residents were relocated, and farming and livestock grazing ceased. Native plants have been slow to re-colonize the abandoned fields. The dominant species on the fields located on the Columbia River Plain are alien annuals, mostly cheatgrass, tumble mustard (Sisymbrium altissimum), jagged chickweed (Holosteum umbellatum), and Russian thistle (Salsola kali). The dominant plant species on old fields located at higher elevations on the ALE Reserve are different. On the Snively Ranch field in the Rattlesnake Hills, black rye (Secale cereale) still dominates the plant community. Many of the shade trees that were planted around the scattered farm houses have survived for 50 years without benefit of irrigation water. The most successful trees are black locust, Siberian elm, and white poplar.

Other areas on the Site that have been disturbed by wildfire, livestock grazing before 1943, defense facilities, and heavy machinery and/or construction activities may support a similar habitat type as that seen in old fields. Cheatgrass and other alien annuals often predominate in these communities, and shrub species such as green and gray rabbitbrush (Chrysothamnus viscidiflorus, C. nauseous) may also be found.

The planted trees provide nesting sites for Swainson's hawks, red-tailed hawks, ferruginous hawks, kestrels (Falco sparverius), great horned owls, great blue herons, black-billed magpies, common ravens, western kingbirds (Tyrannus verticalis), northern orioles and European starlings (Sturnus vulgaris). Some of these same trees also provide browse and shade for mule deer and 
porcupines. The cheatgrass-dominated abandoned fields provide nesting habitat for $\cdots$ 'estern meadowlarks (Sturnella neglecta), horned larks, and long-billed curlews (Allen 1980; ${ }^{(a)}$ ). The abandoned fields are also grazed by flocks of Canada geese in autumn and winter months. ${ }^{(a)}$ Both mammalian and avian fauna are relatively depauparate in old fields relative to shrub-steppe habitat (Rickard et al. 1988).

\subsection{Shrub-Steppe Habitat on the Columbia River Plain}

The Columbia River Plain ranges from low elevations of about 130 to about $260 \mathrm{~m}$ above mean sea level, including the Dry Creek and Cold Creek valleys. Exceptions to the shrub-steppe habitat on the Plain include the rock outcrops that occur on Gable Mountain and Gable Butte, the riparian/ riverine area along the Columbia River, and the abandoned fields. All of the industrial facilities on the Hanford Site are located on the Columbia River Plain.

The shrub-steppe habitats of the Columbia River Plain are commonly recognized on the basis of the dominant shrub and grass species found in a particular stand. Recent wildfires have decimated sagebrush in many areas of the Plain; these habitats are classified according to their dominant grass species. A number of such habitats have been identified, including sagebrush/Sandberg's bluegrass, sagebrush/cheatgrass, bitterbrush/Sandberg's bluegrass, greasewood (Sarcobatus vermiculatus)/ Sandberg's bluegrass, and spiny hopsage/Sandberg's bluegrass (Brandt et al. 1990).

\subsubsection{Shrubs/Sandberg's Bluegrass or Cheatgrass Habitat}

The sagebrush-steppe habitat on the Columbia River Plain is usually dominated by big sagebrush in association with cheatgrass or mixtures of cheatgrass and those native bunchgrasses commonly occurring on sandy and sandy loam soils, including squirreltail (Sitanion hysterix), Sandberg's bluegrass, Indian ricegrass, and needle-and-thread grass. Other shrubs that commonly co-exist with sagebrush in these communities are spiny hopsage, green rabbitbrush, gray rabbitbrush, and bitterbrush. Much of the Columbia River Plain area with sandy or loamy sand soils supports vegetation where bitterbrush and sagebrush are co-dominant. In some areas that appear to be dry lake beds, spiny hopsage or greasewood may dominate the shrub component of the plant community, as described in Section 2.7.3.

The alien annual cheatgrass is a common component of the understory on the plain, comprising 50 to $60 \%$ of the cover in some burned big sagebrush habitats (Brandt et al. 1991, Figure 2.6) of the 200 Area Plateau. Thickspike wheatgrass and Indian ricegrass are the dominant grass species on many extremely sandy areas. Otherwise, the most common grass in all shrub-steppe habitats is Sandberg's bluegrass, which has been found to exceed 30\% cover in portions of the sagebrush/ bitterbrush/Sandberg's bluegrass habitat. The most common shrub in most unburned habitats is big sagebrush. Density of big sagebrush in some areas of the 200 Area Plateau exceeds 20 plants $/ 100 \mathrm{~m}^{2}$ (Brandt et al. 1991, Figure 2.7). Big sagebrush is absent from the pure stands of spiny hopsage

(a) Rickard, W. H. 1994. Birds of Abandoned Cultivated Fields. In preparation, Pacific Northwest Laboratory, Richland, Washington. 


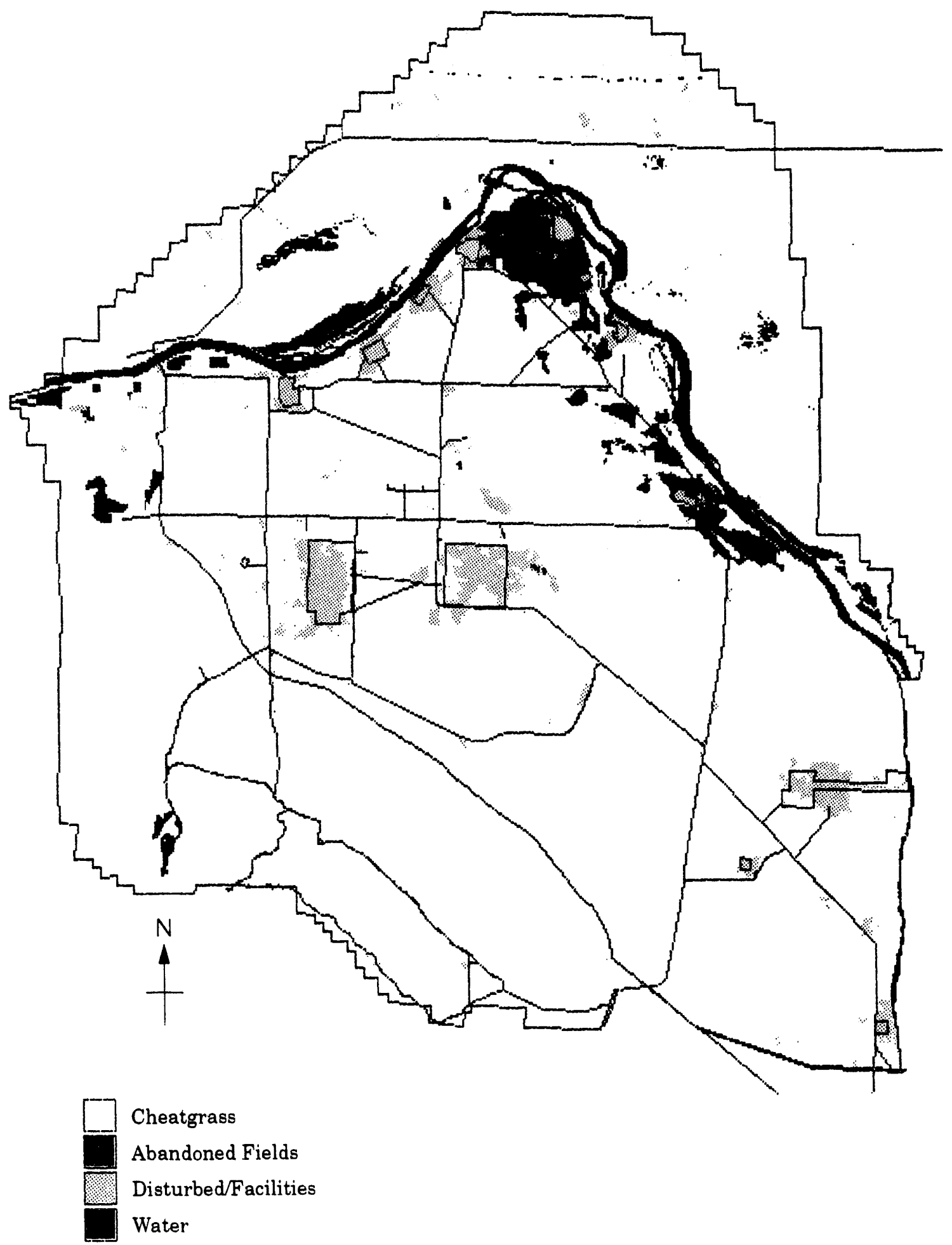

Figure 2.5. Cheatgrass Abandoned Field and Disturbed Habitat Types on the Hanford Site 


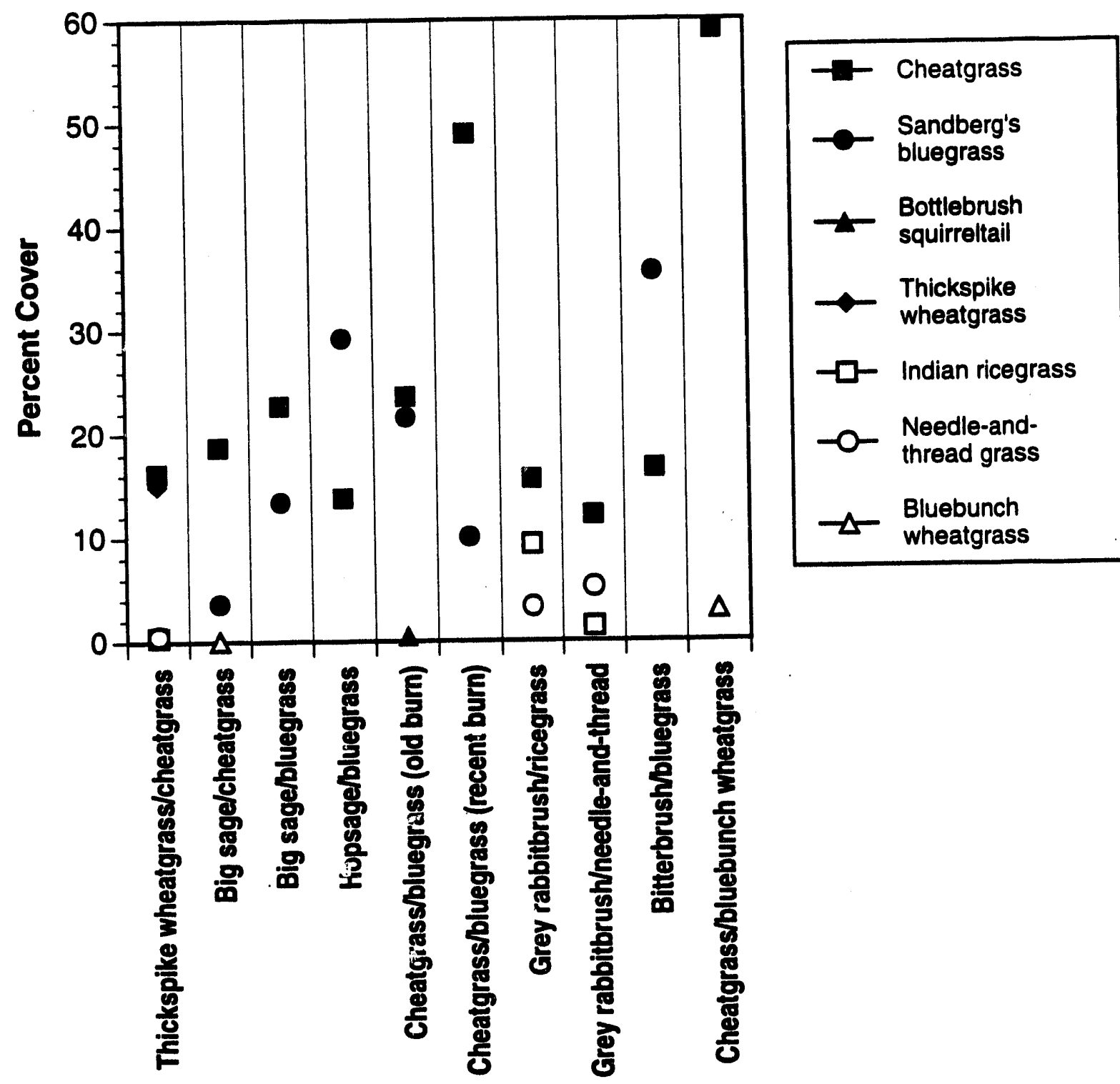

Figure 2.6. Percent Cover of Grasses on Undisturbed Habitats Near Basalt Waste Isolation Project Boreholes in 1989-1990

found near the western portion of the 200 Area Plateau and the upper Cold Creek/Dry Creek valleys (Brandt et al. 1991), and is absent, or nearly so, from the pure greasewoud stands around Rattlesnake Springs.

Areas where stands of mature big sagebrush occur provide an important habitat component for a number of bird and mammal species of concern, including the loggerhead shrike, sage thrasher (Oroscoptes montanus), sage sparrow (Amphispiza belli), pygmy rabbit (Brachylagus idahoensis), and 


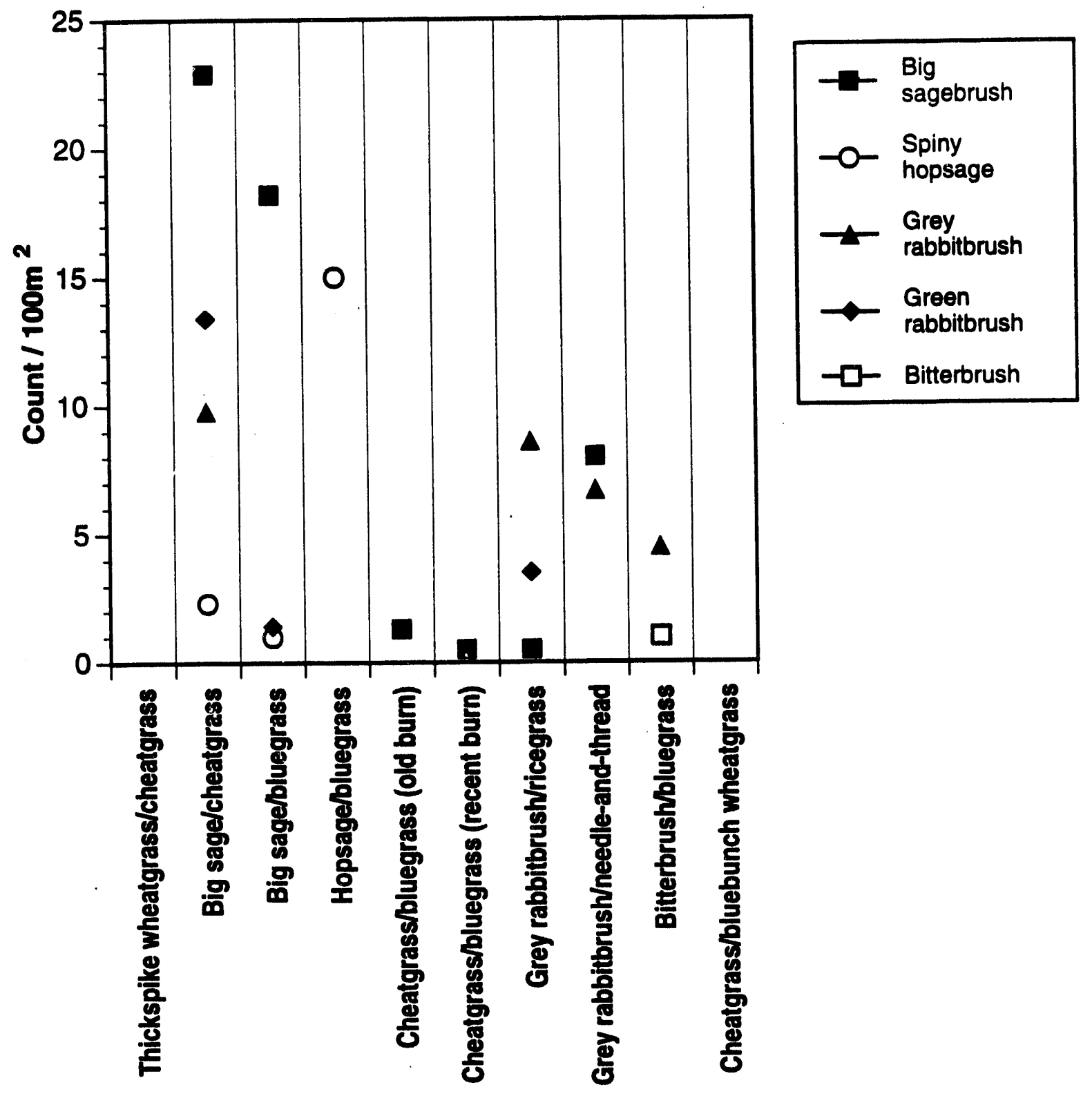

Figure 2.7. Density of Shrubs on Undisturbed Habitats Near Basalt Waste Isolation Project Boreholes in 1989-1990

sage grouse. The loggerhead shrike; sage thrasher, and sage sparrow all require mature big sagebrush for nesting. The sage grouse and the pygmy rabbit require sagebrush as a food source and protective cover.

Other wildlife species that use the sagebrush-steppe stands include a large proportion of Hanford's mule deer population, distributed along the Columbia River, near Gable Mountain, and the 200 Area Plateau. Fur-bearing mammals inhabiting the sagebrush-steppe include badger (Taxidea 
taxus) and coyote (Canis latrans). Black-tailed jackrabbits (Lepus californicus) depend on big sagebrush habitat for food and cover. Deer mice (Peromyscus maniculatus) and pocket mice (Perognathus parvus) are abundant and widely distributed across the Columbia River Plain. Many terrestrial bird species commonly found in other habitat types on the Site also inhabit the Columbia River Plain sagebrush-steppe stands. These include meadowlarks, horned larks, common ravens, and long-billed curlews. Sagebrush-steppe stands on the Columbia River Plain also provide hunting territories for ferruginous hawks, northern harriers (Circus cyaneus), red-tailed hawks, Swainson's hawks, prairie falcons, and golden eagles (Aquila chrysaetos). Sagebrush-steppe areas with recovering shrubs provide important nesting habitat for long-billed curlews. Many existing ferruginous hawk nests occur on power transmission lines on the Columbia River Plain (Appendix A, Figure A.3).

\subsubsection{Recovering Sagebrush Habitat on the Columbia River Plain}

During the 1980s, two wildfires burned desert shrubs from large land areas across the southern half of the Hanford Site. Sagebrush does not regenerate from the roots after fires as do perennial grasses and forbs. In many previously burned areas, sagebrush is reestablishing through seed dispersal and germination, and numerous small-statured $(0.2$ to $0.8 \mathrm{~m}$ tall) sagebrush plants can be observed. These recovering sagebrush communities comprise about $495 \mathrm{~km}^{3}$ of the Hanford Site. Small bitterbrush shrubs are interspersed with establishing sagebrush in areas where soils are sandy. Although these areas will most likely recover to a sagebrush-dominated community over the next several decades, the density and extent of shrub recovery vary greatly across the landscape. The dominant grasses in these communities also vary greatly. Much of the previously burned landscape is dominated by cheatgrass and other annuals; native grasses such as squirreltail, Sandberg's bluegrass, Indian ricegrass, and needle-and-thread grass often coexist with cheatgrass and are the dominant vegetation in certain patches. Commonly occurring perennial forbs include milkvetch (Astragalus spp.), snow buckwheat (Eriogonum niveum), Carey's balsamroot (Balsamorhiza careyana), turpentine spring parsley, and others depending on soils and previous disturbance history. Areas on the Site with recovering shrub habitat are shown in Figure 2.3.

\subsubsection{Hopsage and Greasewood Stands}

Dry lake beds are found in the Cold Creek and Dry Creek valleys. Intermittent flows of run off water from watersheds beyond the Hanford Site historically have pooled on the Columbia River Plain and currently are marked as areas of level topography and fine-textured soils. These areas typically support stands of vegetation dominated by the holophytic shrubs spiny hopsage or greasewood. Small, pure stands of hopsage exist in the Cold Creek Valley west of the 200-West Area (Rickard 1988) and in the vicinity of Goose Egg Hill between Army Loop Road and Highway 240 (see Figure 2.3). Hopsage differs from other desert shrubs on the Hanford Site by accumulating large amounts of potassium in its leaves (Rickard 1965). A small stand of greasewood is located in the Dry Creek Valley near Rattlesnake Springs. Greasewood differs from other desert shrub species on the Hanford Site because it accumulates unusually large quantities of sodium in its leaves and because it depends on root contact with groundwater for its survival in this arid region. Greasewood is resilient to burning and readily sprouts after being burned, but hopsage is killed (Rickard and McShane 1984). Salt grass (Distichilis stricta) is a common species in the understory of greasewood stands. No animals are known to rely only on hopsage or greasewood stands as critical habitat. Neither hopsage nor greasewood appears to be capable of self-establishment from seedlings. 


\subsection{Important Wildlife Species on the Hanford Site}

The following sections describe the wildlife species of special concern on the Hanford Site. Listings include the status of the species where applicable (e.g., state or federal threatened or endangered) and their preferred habitat types. Information also is included on those species commonly found on the Hanford Site that are important either recreationally or commercially or that may be important to include in risk assessments. The information given here on commonly occurring species may not include all species of interest in baseline and risk-assessment evaluations, but the data do illustrate the diversity of Hanford Site wildlife and provide references for further investigation.

\subsection{Avian Species on the Hanford Site}

Landeen et al. (1992) list 36 bird species found on the Hanford Site that are listed as endangered or threatened by Washington State or the federal government, are candidates for such listing, or are listed as monitor species by the state.

Swainson's hawks were downgraded as a federally listed candidate species (from FC2 to FC3) by the U.S. Fish and Wildlife Service in the November 1991 listing (56 FR 58804-36). They have since been listed by Washington State as a candidate for the state's threatened and endangered species list. In addition to the species listed by Landeen et al. (1992) as existing on the Hanford Site, two additional species [Lewis' woodpecker (Melanerpes lewis)-state candidate, flammulated owl (Otus flammeolus)-state candidate] are included as species of concern. Trumpeter swans (Cygnus buccinator) are listed by Landeen et al. (1992) as existing on the Hanford Site, and have been identified by WHC as being a species of potential concern because of their listing as a federal candidate. However, the latest federal listing of candidate species (56 FR 58804-36) identifies only the Rocky Mountain population of the trumpeter swan as a candidate, and lists its historic range as Idaho, Montana, Wyoming, and Canada. Without recovery of banded Rocky Mountain trumpeter swans on the Hanford Site, it is impossible to determine whether any of the birds seen on the Hanford Site were members of the population identified as candidates for listing. Fitzner and Gray (1991) and Stegen (1992) identified the red-necked grebe (Podiceps grisegena) as having been identified on the Hanford Site. Landeen et al. (1992) list this species as having been observed within 50 miles of the Hanford Site. This species is listed as a state monitor species. Finally, the Aleutian subspecies of Canada goose (Branta canadensis leucopareia) has been shot by hunters across the Columbia River from the Hanford Site. Although this subspecies was not identified in previous Hanford bird species listings (Fitzner and Gray 1991; Landeen et al. 1992; Fitzner et al. 1992; Stegen 1992; Weiss and Mitchell 1992; Sackschewsky and Landeen 1992), its possible presence on the Hanford Site is acknowledged.

Table 3.1 lists all bird species that have been documented on the Hanford Site or immediately across the Columbia River that are listed as endangered, threatened, candidate, or monitored by federal or state government. Species considered to be rare migrants or to be present incidentally on the Hanford Site are noted. 
Table 3.1. Threatened, Endangered, Candidate, and Monitor Birds on the Hanford Site

Common Name

Aleutian Canada goose $\mathrm{g}^{(\mathrm{b})}$

American white pelican

Arctic tern ${ }^{(b)}$

Ash-throated flycatcher

Bald eagle

Barred owl ${ }^{(b)}$

Black tern ${ }^{(b)}$

Black-crowned night heron

Black-necked stilt ${ }^{(b)}$

Burrowing owl

Caspian tern

Clark's grebe ${ }^{(b)}$

Common loon

Ferruginous hawk

Flammulated ow $\left.\right|^{(b)}$

Forster's tern

Golden eagle

Grasshopper sparrow

Great blue heron

Great egret ${ }^{(b)}$

Gyrfalcon $^{(b)}$

Horned grebe

Lewis' woodpecker ${ }^{(b)}$

Loggerhead shrike

Long-billed curlew

Merlin $^{(b)}$

Northern goshawk

Osprey

Peregrine falcon ${ }^{(b)}$

Prairie falcon

Red-necked grebe ${ }^{(b)}$

Sage grouse
Association

Habitat ${ }^{(a)}$

Riparian/wetland

Riverine

Riverine

Riparian

Riverine

Riparian/shrub-steppe

Riverine

Riverine

Riverine

Shrub-steppe

Riverine

Riverine

Riverine

Shrub-steppe

Shrub-steppe

Riverine

Shrub-steppe

Shrub-steppe

Riverine

Riverine

Riparian/shrub-steppe

Riverine

Riparian/shrub-steppe

Shrub-steppe

Shrub-steppe

Riparian/shrub-steppe

Shrub-steppe

Riverine/riparian

Riparian/shrub-steppe

Riparian/shrub-steppe

Riverine

Shrub-steppe
Federal Status State Status

Endangered Endangered

Endangered

Monitor

Monitor

Threatened Threatened

Monitor

Candidate Monitor

Monitor

Monitor

Candidate

Monitor

Monitor

Candidate

Candidate

Threatened

Candidate

Monitor

- $\quad$ Candidate

- Monitor

- Monitor

- Monitor

- Monitor

- Monitor

- Candidate

Candidate Candidate

Candidate Monitor

- Monitor

- Candidate

- Monitor

Endangered Endangered

Monitor

Monitor

Candidate

Candidate 
Table 3.1. (contd)

\begin{tabular}{|c|c|c|c|}
\hline Common Name & $\begin{array}{c}\text { Association } \\
\text { Habitat }\end{array}$ & Federal Status & State Status \\
\hline Sage sparrow & Shrub-steppe & - & Candidate \\
\hline Sage thrasher & Shrub-steppe & - & Candidate \\
\hline Sandhill crane & Riparian/shrub-steppe & - & Endangered \\
\hline Snowy owl & Riparian/shrub-steppe & - & Monitor \\
\hline Swainson's hawk & Shrub-steppe & - & Candidate \\
\hline Trumpeter swan ${ }^{(b)}$ & Riverine & Candidate & - \\
\hline Turkey vulture ${ }^{(b)}$ & Riparian/shrub-steppe & - & Monitor \\
\hline Western bluebird ${ }^{(b)}$ & Riparian/shrub-steppe & - & Candidate \\
\hline Western grebe & Riverine & - & Monitor \\
\hline
\end{tabular}

(a) Habitat usage from Fitzner and Gray (1991).

(b) Rare migrant or accidental presence occurrence on the Hanford Site (Fitzner and Gray 1991; Landeen et al. 1992).

\subsubsection{Riparian/Riverine Avian Species}

Shoreline riparian communities are seasonally important to a variety of bird species. Willows trap food for waterfowl (e.g., Canada geese) and shorebirds (e.g., killdeer, spotted sandpiper), and provide nesting habitat for passerines. Planted trees, mostly black locust, Siberian elm, and white poplar, located near the rivershore are used as night roosts and daytime perches by bald eagles in winter (Eisner 1991). Some shoreline trees are used as nesting sites by great blue herons, black-tailed magpies, northern orioles, and other birds.

Waterfowl: The most abundant resident waterfowl species is the Canada goose, which nests on islands of the Hanford Reach (Hanson and Eberhardt 1971). Forster's tern (Sterna forsteri), ring-billed gulls (Larus delawarensis), and California gulls (L. californicus) are also island nesters.

Wintering waterfowl represent a primary biological resource on the Hanford Reach. Currently, 23 duck species use the Reach for resting and feeding, although overall use has declined in the recent past (Fitzner et al. 1992). Declines could be attributed to changes in management of downstream areas, changes in land management offsite, or changes in crop production in fields adjoining the Reach. These factors, or intermittent foraging habitat (e.g., sloughs and backwater areas), may be responsible for the uneven distribution of waterfowl throughout the Reach. 
The Hanford Reach is off-limits to waterfowl hunting, from the powerline crossing at Hanford Townsite upstream to the Vernita Bridge. This designation affords a refuge that accommodates the resting and feeding activity of these birds. The limited distribution of nesting habitat reduces the production potential of the Hanford Reach for waterfowl. The primary nesting species along the Reach are the mallard (Anas platyrhynchos) and Canada goose. However, gadwall (A. strepera), teal ( $A$. crecca), and common merganser (Mergus merganser) also take advantage of nesting habitat afforded along the river shorelines.

The Hanford Reach is a primary production site for Canada geese. Canada goose broods rely heavily on riparian herbs as food sources during the weeks after hatching until the time the young birds are able to fly. Mature birds forage in pastures, irrigated fields, and in the shrub-steppe habitat of the near-shore environment (Eberhardt et al. 1989; Rickard et al. 1990). Canada goose broods may cover a range from 2.8 to $18.1 \mathrm{~km}$ along the river (Rickard et al. 1982).

Nesting Canada geese are monitored each year as part of PNL's Wildlife Resources Monitoring Project. During 1993, 264 pairs of Canada geese nested within the Hanford Reach. Twenty-four nesting pairs occurred on U.S. Fish and Wildlife Service Island 21 in the McNary Pool. Production during 1993 was consistent with previous years, with hatching success affected by predation and fluctuations in surface-water elevation at up- and downstream areas of the reach. Nesting success in the upstream portion of the Hanford Reach remains suppressed and is likely the result of coyote predation on near-shore islands.

Colonial Nesting Species and Shorebirds: Colonial nesting species, including Forster's tern, California gull, ring-billed gull, and great blue heron, have established significant breeding populations within the Hanford Reach. Black-crowned night herons (Nycticorax nycticorax) and white pelicans (Pelecanus erythrorhynchos), a state endangered species, are a desired species for management by the Washington Department of Wildlife. White pelicans occur as residents within the Hanford Reach. During June 1993, several flocks of these birds were observed within the Hanford Reach. Although numbers of white pelicans using the Reach during winter are increasing, currently no nesting has been recorded. Approximately 300 American white pelicans used the Hanford Reach of the Columbia River during summer 1989 (Fitzner and Gray 1991). Their primary prey consists of carp and suckers. Black-crowned night herons are present within the Reach during spring and summer. This bird forages along the shoreline, consuming species also taken by great blue herons [primarily fish, amphibians, aquatic invertebrates, and small mammals (Terres 1980)]. During 1993, night herons were observed in association with the canopy of riparian vegetation along island shorelines. Both black-crowned night herons and great blue herons nest on the Hanford Site. Caspian terns (Sterna caspia) nest on Columbia River islands (Stegen 1992) and consume much the same prey as Forster's terns. Common loons (Gavia immer) are rare breeders on the Hanford Site (Stegen 1992); they feed on fish, amphibians, and aquatic invertebrates. Horned grebes (Podiceps auritus) and western grebes (Aechmorphous occidentalis) are winter visitors to the Columbia River on the Hanford Site.

In 1977, approximately 60 pairs of long-billed curlews were estimated to have been nesting in the 600 Area of the Hanford Site (Allen 1980). Curlews nest from April through June in relatively flat areas dominated by cheatgrass. They feed primarily on beetles and subterranean insect larvae (Allen 1980). No systematic surveys of the site have been conducted since Allen's study (Fitzner 
et al. 1992). Allen also identified a high-use curlew nesting area just west of the 300 Area (Allen 1980). Nestlings are prey primarily to ravens, magpies, and coyotes (Allen 1980). This species should be considered of potential interest from an ecological risk perspective.

\subsubsection{Raptor Species}

The peregrine falcon is listed as a species of concern in the biological assessment for CERCLA activities (Fitzner et al. 1992); however, it is an erratic visitor to the Hanford Site. This species does not nest on the Site. Peregrine falcons occasionally are noted during the winter months during migration and may actually winter in the area, particularly near the Yakima Delta. They have been sighted three times (four birds) near the 300 Area in past years, with several additional sightings on the Hanford Site in 1993 including the vicinity of White Bluffs and near the Wye Barricade. The birds apparently do not use the Hanford Site for anything more than a migratory stopover (Fitzner et al. 1992). Therefore, they are not included as a species of potential concern in this report.

Bald eagles do not nest on the Hanford Site, although as many as 40 bald eagles winter on the Hanford Site from November through March (Fitzner and Weiss 1992; Appendix A, Figure A.2). Two nesting attempts were recorded by the 100-F Reactor in 1991 and 1992 . The wintering bald eagle population is monitored as part of PNL's Wildlife Resources Monitoring Project. The eagles. forage primarily on Chinook salmon (Oncorhynchus tschawytscha) and mallard ducks (41 and 39\% of dietary biomass, respectively) (Fitzner and Hanson 1979). Other foods bald eagles eat include other waterfowl and fish species associated with the river ecosystem (Fitzner and Hanson 1979). The primary foraging areas of these birds lie between the Hanford Townsite and the Vernita Bridge (Fitzner and Weiss 1992).

Approximately 50 pairs of ferruginous hawks nested in Washington State in 1991 (Fitzner et al. 1992). Ten active ferruginous hawk nests were found on the Hanford Site in 1991, with eight located in either high-tension electric transmission towers or trees (Fitzner et al. 1992). These hawks are reported to feed primarily on small- to medium-sized mammals such as rabbits and ground squirrels (Howard and Wolfe 1976; Fitzner et al. 1981). A current dietary study (K. Lehmkuhl 1993, personal communication) indicates that northern pocket gophers (Thomomys talpoides) are a major component of ferruginous hawks' diet on the Hanford Site. This species should be considered of potential interest from an ecological risk perspective. Active nests of ferruginous, red-tailed, and Swainson's hawks are monitored through PNL's Wildlife Resources Monitoring Project (Appendix A, Figures A.3 and A.4).

Approximately 15 to 20 pairs of Swainson's hawks nest in trees on the Hanford Site (Fitzner et al. 1981) from April to September. These nests have been in continuous use since at least 1975 (Fitzner et al. 1981). Swainson's hawks feed primarily on snakes, medium-sized mammals, and insects, with yellow-bellied racers being the most important prey (Fitzner 1980). This species should be considered of potential interest from an ecological-risk perspective.

Raptors such as the red-tailed hawk, northern harrier, and rough-legged hawk (Buteo lagopus), are top predators with large home ranges. Red-tailed hawks are the most common hawks nesting on the Hanford Site. At least 20 nesting pairs occupy the site, including at least one nest within $10 \mathrm{~km}$ of the 300-FF-5 Area (Fitzner et al. 1981). On the Site, most nesting occurs in utility towers, on 
Gable Butte, and in larger trees (Fitzner et al. 1981). Red-tailed hawks on the Site primarily feed on medium-sized mammals, such as black-tailed jackrabbits (Lepus californicus) and Townsend's ground squirrels (Spermophilus townsendii), and on snakes (Fitzner et al. 1981).

Northern harriers are one of the most common diurnal raptors on the Hanford Site and are present year-round. These ground-nesting hawks favor riparian habitat and tall grassy fields for nesting (Fitzner et al. 1981). Northern harriers primarily prey on small birds and small mammals (Fitzner et al. 1981).

Burrowing owls (Athene cunicularia) are widely distributed on the Hanford Site. The nesting population during the mid-1970s was estimated at 20 to 26 pairs (Fitzner et al. 1981). Most nest sites are found in abandoned badger and coyote burrows, although no systematic survey of the Hanford Site has been conducted to determine the nesting locations of these birds (Rickard and Poole 1989). These small owls are primarily insect and small-mammal predators. Insects represent the majority of prey captures, but Great Basin pocket mice form the major part of their diet in terms of biomass (Fitzner et al. 1981).

\subsubsection{Passerine Species}

Loggerhead shrikes are year-round residents on the Hanford Site, although they occur at relatively low densities (Fitzner et al. 1981). They nest from March through August in undisturbed portions of the big sagebrush/Sandberg's bluegrass community, where they average $3.5 \mathrm{pairs} / \mathrm{km}^{2}$ in the 200 Area Plateau (Poole 1992) (Appendix A, Figure A.1). These medium-sized passerines feed on insects, small mammals, and birds (Fitzner and Rickard 1975). Nestlings are prey to gopher snakes (Pituophis melanoleucus), black-billed magpies. sommon ravens, and coyotes (Poole 1992). This species should be considered of potential interest from an ecological risk perspective.

Sage sparrows are a common summer resident of the Hanford Site (Fitzner and Rickard 1975). These small passerines are restricted in their distribution almost entirely to sagebrush stands (Schuler et al. 1988). Sage sparrow abundance on the 200 Area Plateau has been shown to be related to sagebrush density (Schuler et al. 1988), although abundance may vary widely between years due to natural environmental variation (Rotenberry 1980). Sage sparrows are the second most abundant bird in the undisturbed areas of the 200 Area Plateau, reaching densities of $7.5 \mathrm{birds} / \mathrm{km}^{2}$ (Schuler et al. 1988). They forage primarily on phytophagous (plant-eating) beetles and other arthropods, with seeds composing less than 5\% of their diet (Rotenberry 1980). This species should be considered of potential interest from an ecological risk perspective.

The western meadowlark is the most abundant bird found in the shrub-steppe habitat of Columbia River Plain (Brandt and Rickard 1992), and are present throughout the year (Fitzner and Rickard 1975), nesting on the ground from April through July (Brandt and Rickard 1992). Their diet is composed almost entirely of phytophagous insects (Rotenberry 1980). Meadowlark abundance in sagebrush habitat on the Hanford Site was estimated to be approximately $11 \mathrm{birds} / \mathrm{km}^{2}$ (Schuler et al. 1988).

Songbirds that occur along the Hanford Reach nest within willow, cottonwood, and mulberry trees and shrubs along the shoreline and also on the cliffs at White Bluffs. Common species include 
the eastern kingbird (Tyrannus tyrannus), horned lark, cliff swallow, barn swallow (H. rustica), black-billed magpie, common raven, American robin, European starling (Sturnus vulgaris), yellow-rumped warbler (Dendroica coronata), white-crowned sparrow, dark-eyed junco, western meadowlark, red-winged blackbird (Agelaius phoeniceus), house finch (Carpodacus mexicanus), and house sparrow (Passer domesticus) (Landeen et al. 1992). White-crowned sparrows are abundant winter migrants on the Hanford Site. Western kingbirds nest in trees, shrubs, crevices in buildings, and on powerline poles, and consume primarily insect prey (Terres 1980). Relatively little information exists for these species on the Hanford Site.

\subsubsection{Upland Game Birds}

Sage grouse are a state threatened species and were once routinely observed in sagebrush-steppe above $250 \mathrm{~m}$ on the Hanford Site. In recent years, however, no birds have been observed. These birds require sagebrush as a habitat component; their numbers apparently declined after wildfires removed much of the sagebrush from the Site. A few birds may still use remote portions of the ALE Reserve during some seasons of the year, but surveys during the spring months of 1993 did not locate any birds.

Other game bird species present on the Hanford Site include the mourning dove (Zenaida maroura) California quail (Callipepla californica), ring-necked pheasant (Phasianus colchicus), Hungarian partridge (Perdix perdix), and chukar partridge. California quail often can be found near riparian areas and in abandoned orchards near the Columbia River shoreline. The ring-necked pheasant is most often found in association with riparian vegetation near a water source. Hungarian partridge and chukar partridge are common inhabitants of sagebrush-steppe areas above $250 \mathrm{~m}$, but are also found near areas where water is easily accessible. Chukars are concentrated in the vicinity of West Lake and along the spring streams in the Rattlesnake Hills.

\subsection{Mammalian Species}

Approximately 40 species of mammals have been identified at Hanford or as potential residents of the Site (Cushing 1992; Fitzner and Gray 1991; Fitzner et al. 1992). Of these species, some 30 are known to be associated with buildings, the Columbia River or riparian zones, and the shrubsteppe environment of the Columbia River Plain (Fitzner and Gray 1991) (Table 3.2). In general, greater diversity of both plants and animals occurs in shrub-steppe areas of the Hanford Site at elevations greater than $250 \mathrm{~m}$ than in sagebrush-steppe habitats on the Columbia River Plain. Much of this higher elevation habitat is located on the protected ALE Reserve.

The most abundant small mammal on the nonriparian portion of the Columbia River Plain is the Great Basin pocket mouse (Fitzner et al. 1979; Thiede 1992). Although primarily a granivore, the pocket mouse also consumes insects early in the year before seed production (Johnson 1975). Pocket mice constitute the principal prey for burrowing owls, great horned owls, long-eared owls (Asio otus), and barn owls (Tyto alba) foraging on the Hanford Site (Fitzner et al. 1981). Densities may range between 20 and 75 mice/ha in April depending on the habitat (Gano and Rickard 1982). Densities of pocket mice occurring in cheatgrass habitat have been estimated at 30/ha (Hedlund et al. 1975). 
Table 3.2. Mammals Existing on the Hanford Site

\begin{tabular}{|c|c|c|c|c|}
\hline Pamily & Common Name & Latin Name & Abundance & Habitat Association \\
\hline \multirow[t]{2}{*}{ Soricidae } & Vagrant shrew & Sorex vagrans & Uncommon & Riparian \\
\hline & Merriam's shrew & Sorex merriand & Rare & \\
\hline \multirow[t]{6}{*}{ Vespertilionidse } & Pallid bat & Antrozous pallidus & Common - summer & Buildings/riparian \\
\hline & Little brown myotis & Myotis lucifugus & Common - summer & Buildings/riparian \\
\hline & Yuma myotis & Myotis yumanenusis & Common - summer & Buildings/riparian \\
\hline & Silver-haired bat & Lasionycteris noctivagans & Unknown & Buildings/riparian \\
\hline & Hoary bat & Lasiurus cinereus & Unknown & Buildings/riparian \\
\hline & Townsend's big-eared bat & Plecotus townsendii & Unknown & Buildings \\
\hline \multirow[t]{3}{*}{ Leporidse } & Black-tniled jackrabbit & Lepus califormicus & Common & Shrublands/grasslands \\
\hline & Nuttall's cottontail & Sylvilagus nuttallii & Common & Buildings \\
\hline & Whito-tailed jackrabbit & Lepus sownsendi & Uncommon & Shrublands/grasslands \\
\hline \multirow[t]{3}{*}{ Sciuridae } & $\begin{array}{l}\text { Townsend ground squirrel } \\
\text { Least chipmunk }\end{array}$ & $\begin{array}{l}\text { Spermophilus townsendii } \\
\text { Eutamias minimum }\end{array}$ & $\begin{array}{l}\text { Common } \\
\text { Uncommon }\end{array}$ & $\begin{array}{l}\text { Shrublands/grasslands } \\
\text { High elevation } \\
\text { shrublands }\end{array}$ \\
\hline & Yellow-bellied marmot & Marmota flaviventris & Rare & Basalt outcrops \\
\hline & Sagebruch vole & Lagurus curtatus & Uncommon & Shrublands/grasslands \\
\hline Geomyidee & Northern pocket gopher & Thomomys talpoides & Common & Shrublands/grasslands \\
\hline Heteromyidne & Great Basin pocket mouse & Perognathus parvus & Common & Shrublands/grasslands \\
\hline Castoridae & Beaver & Castor canadensis & Common & Riverine/riparian \\
\hline \multirow[t]{6}{*}{ Cricetides } & Western harvest mouse & Reithrodontomys megalotis & Rare & Shrublands/riparian \\
\hline & Deer mouse & Peromyscus maniculatus & Common & Entire site \\
\hline & Northern grasahopper mouse & Onychomys leucogaster & Raro & Riparian \\
\hline & Bushy-triled wood rat & Neotoma cinerea & Common & Entire site \\
\hline & Montane vole & Microtus montanus & Rare & Riparian \\
\hline & Muskrat & Ondatra zibethica & Rare & Riverine/riparian \\
\hline \multirow[t]{2}{*}{ Muridee } & Norway rat & Ratrus norvegicus & Common & Buildings \\
\hline & House mouse & Mus musculus & Common & Buildings/riparian \\
\hline Erethizontidae & Porcupine & Erithizon dorsatum & Uncommon & Entire site \\
\hline Canidae & Coyote & Canis latrans & Uncommon & Entire site \\
\hline Procyonidae & Raccoon & Procyon lotor & Uncommon & Ripurian \\
\hline \multirow[t]{6}{*}{ Mustelidao } & Mink & Mustela vison & Rare & Riverine/riparian \\
\hline & Long-tailed weasel & Mustela frenata & Uncommon & Riparian \\
\hline & Short-tailed weasel & Mustela erminea & Rare & Riparian \\
\hline & Otter & Lutra canadensis & Rare & Riverine/riparian \\
\hline & Badger & Taxidea taxus & Uncommon & Entire site \\
\hline & Striped skunk & Mephitis mephitis & Uncommon & Riparian \\
\hline Felidae & Bobcat & Lynx rufius & Rare & Entire site \\
\hline \multirow[t]{3}{*}{ Cervidae } & Mule deer & Odocoileus hemionus & Common & Entire site \\
\hline & Elk & Cervus elaphus & Common & Shrublands/grasslands \\
\hline & White-tailed deer & Odocoileus virginianus & Rare & Riparian \\
\hline
\end{tabular}


The second most abundant mammal on the Hanford Site is the deer mouse (Peromyscus maniculatus). Deer mice are omnivorous, concentrating on green vegetation, especially tansy mustard (Descurainia pinnata) and cheatgrass (Hedlund and Rogers 1976). Although nocturnal, deer mice often fall prey to Swainson's hawks and red-tailed hawks nesting on the Hanford Site. More frequently, they are consumed by great horned owls, long-eared owls, burrowing owls, and barn owls (Fitzner et al. 1981).

House mice (Mus musculus) are found in association with human habitations and construction, and seldom on the shrub-steppe itself (Rickard et al. 1974). In consequence, house mice have seldom been found in the diets of owls or hawks that have been studied on the Hanford Site (Fitzner et al. 1981), although they are a common constituent of barn owl diets (Terres 1980).

The distribution of the western harvest mouse (Reithrodontomys megalotis) on the lowland portions of the Hanford Site is thought to be limited to riparian vegetation (O'Farrell et al. 1975). Evidence has been found that Hanford's long-eared owls consume harvest mice, though in relatively small proportions (Fitzner et al. 1981).

The northern grasshopper mouse (Onychomys leucogaster) occurs on the Hanford Site, but is apparently sparsely distributed. O'Farrell (1975) suggested that the distribution of this insectivorous animal is tied to the distribution of ground-dwelling beetles. The grasshopper mouse is a rare component of the diet of long-eared owls on the Hanford Site (Fitzner et al. 1981).

Townsend's ground squirrels (Spermophilus townsendii) are present in habitats around the 300 Area (Fitzner et al. 1979; Thiede 1992), and their home range is expected to include much of the grasslands on Site. Foraging preferences based on analyses of fecal samples identified Sandberg's bluegrass and tumble mustard as preferred food items (Johnson 1975; Rogers and Gano 1980). Townsend's ground squirrels are the principal food item for red-tailed hawks and the second most important item in the diet of post-fledgling Swainson's hawks on the Hanford Site (Fitzner et al. 1981).

Although seldom observed by humans, the fossorial northern pocket gopher (Thomomys talpoides) is an abundant small mammal whose mounded castings are a telltale characteristic on the surface of fine-textured soils inhabited by this species. Pocket gophers make extensive burrows in the top $0.50 \mathrm{~m}$ of soil and are responsible for much of the observed soil turn-over in this semi-arid climate. They are herbivores and consume both roots and aboveground plant parts. They are important prey species for badgers that dig them from their burrows and for owls and hawks that take them during late evening, early morning, and at night when the gophers emerge from a temporary opening they make in their burrow systems. Little study of this species has been made at Hanford on the animal's role in soil formation, water infiltration, incursion, and as a prey base.

The striped skunk (Mephitis mephitis) inhabits riparian areas in desert climates and has been frequently observed along the Columbia River and rarely on the ALE Reserve. Because of its nocturnal habit, the striped skunk is not often encountered by members of the Hanford Site work force. 
The porcupine (Erethizon dorsatum), much like the skunk, occupies riparian areas of the Hanford Site. Porcupines are usually found in trees where they feed on the bark of small limbs and branches. The Columbia River shoreline, particularly near the Hanford Townsite and Snively Canyon on the ALE Reserve each have sufficient woody vegetation to maintain populations of porcupine. Although wooded areas provide preferred habitat for porcupines, they will feed on other types of vegetation and may occasionally be encountered nearly anywhere on the Hanford Site.

The bushytail woodrat (Neotoma cinerea) is common on the Hanford Site and can be found in rock outcrops and talus slopes. Abandoned buildings are also frequented by this species. This woodrat species does not usually build large houses, but is known to accumulate sticks, bones, and other cbjects in crevices or under structures.

The pallid bat (Antrozous pallidus) is a common summer inhabitant of the Hanford Site and has been found in deserted buildings within the 100 and 200 Areas. Fitzner and Gray (1991) reported finding more than 100 female pallid bats with young in the 100-F Reactor Building.

The silver-haired bat (Lasionycteris noctivagans) is distributed throughout most of the conterminous United States. It has not been studied on the Hanford Site. The silver-haired bat is assumed to roost in trees; however, there is little evidence that this is a preferred habitat (Kunz 1982). This species is known to roost in caves, hollow trees, and houses during the winter (Kunz 1982). It forages for insects in the vicinity of trees, ponds, streams, and other water bodies (Kunz 1982). Its distribution on the Hanford Site is therefore likely to be restricted to riparian areas, although potential habitat exists on Gable Mountain and Gable Butte, and in abandoned buildings in the 200 Areas.

The hoary bat (Lasiurus cinereus) has not been studied on the Hanford Site. In the Blue Mountains of Washington and Oregon, the species is migratory, using the area between April and November (Thomas 1979). It roosts solitarily in trees, and is known to forage for insects primarily in forested areas. Its range is therefore likely to be restricted to riparian habitats (Thomas 1979).

Townsend's big-eared bat (Plecotus townsendii) is a medium-sized, light brown bat with the longest ears of any bat on the Hanford Site. This bat is primarily a cave-dwelling species, but also will roost in buildings. It is associated with pine and juniper forests and semi-arid habitats, where it forages on insects. Females roost in small groups, but males generally roost singly, except during mating, which occurs in the fall. Young are born from late May to July. No studies of this bat on the Hanford Site have been published, although it is presumed foraging and habitat range would be limited to the riparian and riverine areas of the Site, especially near abandoned buildings and tunnels. Townsend's big-eared bat is a candidate for protection under the Endangered Species Act.

Merriam's shrews (Sorex merriami) and vagrant shrews (Sorex vagrans) have been occasionally captured on the Hanford Site (Rickard et al. 1974; Rogers and Rickard 1977). Vagrant shrews are thought to occur primarily in riparian portions of the Hanford Site, such as near Rattlesnake Springs and the Columbia River (Rickard et al. 1974). Merriam's shrews are thought to be most abundant in the three-tip sagebrush and old-growth big sagebrush communities at higher elevations, although they are not an uncommon dietary component of long-eared owls and burrowing owls on the Hanford Site (Fitzner et al. 1981). 
Montane voles (Microtus montanus) are generally associated with dense, herbaceous vegetation of riparian areas along the Columbia River (Rickard et al. 1974). These creatures are occasionally taken by owls hunting on the Hanford Site, and are thought to be a relatively scarce component of the small mammal community (Fitzner et al. 1981). Montane voles also use the abandoned fields associated with Snively Canyon on the ALE Reserve where Snively Creek and Dry Creek provide easily accessible water.

The sagebrush vole (Lagurus curtatus) occurs in sagebrush habitats on the Hanford Site, although its distribution appears to be limited to higher elevations (Rickard et al. 1974). Before 1972, only four sagebrush voles had been captured on the Site at elevations below $1000 \mathrm{ft}$, and all four were captured near Rattlesnake Springs (O'Farrell 1972; 1975). Most captures have been at upper elevations on Rattlesnake Mountain (O'Farrell 1972; 1975). An intensive trapping effort (5000 trap nights) near the B-C cribs area on the 200 Area Plateau obtained a single sagebrush vole (Hedlund and Rogers 1976). The distribution of sagebrush voles appears to be tied to the big sagebrush/bluebunch wheatgrass plant community (O'Farrell 1972). Sagebrush voles are occasionally found in the diets of great horned owls and long-eared owls on the Hanford Site (Fitzner et al. 1981). They consume primarily green vegetation from grasses, forbs, and big sagebrush (James and Booth 1952).

Least chipmunks (Eutamius minimus) occur on the Hanford Site in the upper elevations of Rattlesnake Mountain. They are primarily granivores, feeding on seeds of grasses and forbs, although they also consume insects when available (Jameson and Peters 1988), and dig burrows for shelter and reproduction.

Yellow-bellied marmots (Marmota flaviventris) occur on the Hanford Site primarily in the vicinity of rock outcrops, under which they construct burrows for use as refuges and hibernacula (Frase and Hoffmann 1980). This species hibernates from July through late February, emerging to forage on the accumulated winter growth of the native plants (Hall 1946). They consume primarily grasses and forbs (Armitage 1979). Yellow-bellied marmots have not been studied on the Hanford Site.

Black-tailed jackrabbits are found in nearly all habitats in the shrub-steppe region, and are the most common lagomorph on the Hanford Site (Rickard et al. 1974). Black-tailed jackrabbits on the Columbia River Plain feed most heavily on needle-and-thread grass, yarrow, turpentine cymopterus, and tumble mustard (Uresk et al. 1975), and depend on shrubs for protective cover. Black-tailed jackrabbits are the principal prey of golden eagles wintering on the Hanford Site (Rickard et al. 1974) and are important constituents in the diets of great horned owls, long-eared owls, barn owls, ferruginous hawks, Swainson's hawks, and red-tailed hawks (Fitzner et al. 1981).

White-tailed jackrabbits (Lepus townsendi) occur in sagebrush/bunchgrass habitats, generally at higher elevations than black-tailed jackrabbits. Their diet consists primarily of forbs during the summer months, and shrubs in the winter (James 1967). They are primarily nocturnal, using shrubs and/or shallow burrows for cover during the day (Flux and Angermann 1990). They are classified as protected wildlife by the state of Washington.

Nuttall's cottontails (Syvilagus nuttallii) are expected to occur where badger burrows or other cover, such as that found associated with human construction, are available (Rickard et al. 1974). Cottontails are major constituents in the diets of great horned owls, long-eared owls, barn owls, 
red-tailed hawks, Swainson's hawks, prairie falcons, and ferruginous hawks feeding on the Hanford Site (Fitzner et al. 1981). No data are available describing the density of Nuttall's cottontails on the Hanford Site. Nuttall's cottontails were observed on the 300 Area waste sites (Fitzner et al. 1979; Rickard et al. 1990).

Pygmy rabbits (Brachylagus idahoensis) were reported from one area on the ALE Reserve (Fitzner and Gray 1991). No pygmy rabbit colony has existed at the original area of the sighting since wildfires removed sagebrush from the area in 1984. These are the smallest rabbits in North America and the only rabbit in North America to dig its own burrows (WDW 1993). Pygmy rabbits depend heavily on sagebrush, which comprises up to $99 \%$ of its diet. Dense sagebrush growing on relatively deep, loose soils are important habitat characteristics for this species. Surveys of likely sagebrush habitat on the Site during the winter and spring months of 1992-1993 were conducted; however, no individuals of this species or evidence of pygmy rabbit burrows were found. Because of the decline of the pygmy rabbit in Washington, this species has been recommended to be upgraded from a listing as state threatened to state endangered (WDW 1993).

Musirats (Ondatra zibethica) are associated with riparian areas on the Hanford Site, occurring in ponds and ditches (Rogers and Rickard 1977), as well as the Columbia River and its backwaters (Rickard et al. 1974). Their numbers and details of their distributions have not been determined. They are occasionally taken by great horned owls and larger raptors, though in apparently small numbers (Rickard et al. 1974; Fitzner et al. 1981).

Beavers (Castor canadensis) are the largest members of the rodent family in North America. They are semi-aquatic, spending most of their lives in the water. They are commonly associated with the construction of beaver dams; however, animals on large rivers such as the Columbia construct only lodges along the river banks (Hill 1982). They consume the leaves, young twigs, and cambium of willow and other riparian trees, while their primary predator is the coyote (Hill 1982; Rickard et al. 1974).

River otters (Latra canadensis) are seldom seen along the Columbia River. However, the few recent sitings of this species may indicate that a few breeding pairs exist in the Hanford Reach.

Coyotes are the most abundant large carnivores on the Hanford Site. They have not been studied to any extent on the Hanford Site except on the ALE Reserve. Their diet is diverse, reflecting the availability of prey. Where the Great Basin pocket mouse is most abundant in the habitat, they have been found to be most abundant in the coyote diet (Stoel 1976). Other prey include leporids, voles, pocket gophers, ground squirrels, mule deer fawns, birds, reptiles, beetles, and grasshoppers (Stoel 1976; Steigers and Flinders 1980). Coyote density on the ALE Reserve has been estimated at 1 coyote $/ 2.5 \mathrm{~km}^{2}$ (Crabtree 1989); Steigers and Flinders (1980) estimated coyote density near the Columbia River to be 1 coyote $/ 4 \mathrm{~km}^{2}$.

Raccoons (Procyon lotor) are nocturnal carnivores that inhabit the riparian areas of the Columbia River (Rickard et al. 1974). They feed on a variety of prey, including fish, crustaceans, insects, reptiles, amphibians, birds, and other mammals (Kaufmann 1982). No studies of this mammal have been conducted on the Hanford Site. 
Long-tailed weasels (Mustela frenata) are scarce inhabitants of the Hanford area. They have been reported on the ALE Reserve and in riparian habitats along the Columbia River (Rickard et al. 1974). Their primary prey includes rodents, shrews, and young rabbits (Svendsen 1982).

Badgers are a carnivore not commonly observed on the Hanford Site and their densities in this area are unknown. Estimates of badger densities in similar habitats of south-central Idaho ranged from 2 to 7 badgers $/ \mathrm{km}^{2}$ (Messick and Hornocker 1981). Badger home-range sizes range from 0.2 to $4.0 \mathrm{~km}^{2}$ (Messick and Hornocker 1981). These animals feed primarily on ground squirrels, small mammals, and arthropods (Messick and Hornocker 1981). Excavations by badgers were found in the 300 Area burial grounds (Fitzner et al. 1979; Rickard et al. 1990).

Mule deer are common and range over the entire Hanford Site at various times of the year. The greatest concentrations of deer are along the Columbia River, near Gable Mountain, and on the 200 Area Plateau. Deer are usually dispersed throughout favorable habitats in small groups or singly. These mule deer are mainly forb and shrub consumers (Uresk and Uresk 1980). Natural mortality of mule deer fawns on the Hanford Site is relatively high, mostly as a result of coyote predation (Steigers and Flinders 1980). Mule deer home ranges average approximately $40 \mathrm{~km}^{2}$ (Eberhardt et al. 1982), with densities near the Columbia River of approximately 1 deer/60 ha (Steigers and Flinders 1980). Population estimates of the number of deer on the Hanford Site have not been completed, but it is generally believed that "several hundred" mule deer inhabit the Site. Habitat use, movement, and population dynamics are currently under study as part of PNL's Wildlife Resources Monitoring Project.

Elk are a relatively recent addition to Hanford Site wildlife and the elk population is monitored annually by PNL's Wildlife Resources Monitoring Project. A small number of elk were first noted on the ALE Reserve in the early 1970s. The herd has grown in size to about 250 animals that range primarily on the ALE Reserve and nearby private, state, and federal properties (Appendix A, Figure A.5). Elk have not been observed using the portion of the Hanford Site that lies to the east of state highway 240. While on the Hanford Site, these animals use areas on the slopes of the Rattlesnake Hills and the Yakima and Umtanum ridges.

\subsection{Reptiles and Amphibians}

Common herpetiles (reptiles and amphibians) of the shrub-steppe habitats on the Hanford Site are listed in Table 3.3. Side-blotched lizards (Uta stansburiana) are by far the most abundant reptile in all these habitats, but do not appear to inhabit areas above $400 \mathrm{~m}$ (Rickard 1968). The most common snakes are the western yellow-bellied racer (Coluber constrictor) and the Great Basin gopher snake (Pituophis melanoleucus). Snakes are active from April until October (Nussbaum et al. 1983). Striped whipsnakes (Masticophis taeniatus), a state candidate species, and desert nightsnakes (Hypsiglena torquata) are found very infrequently on site. The Northern Pacific rattlesnake (Crotalus viridis) and the desert nightsnake are most often found in or near basalt outcrops (Fitzner and Gray 1991). The painted turtle (Chrysemys picta) is also listed by Fitzner and Gray (1991) as occurring in ponds on the Hanford Site. 
Table 3.3. Common Reptiles and Amphibians of Shrub-Steppe Habitats on the Hanford Site

\begin{tabular}{l} 
Common Name \\
\hline Western yellow-bellied racer \\
Great Basin gopher snake \\
Northern Pacific rattlesnake \\
Northern sagebrush lizard \\
Side-blotched lizard \\
Great Basin spadefoot toad \\
Woodhouse's toad \\
Pacific treefrog
\end{tabular}

\begin{tabular}{l} 
Scientific Name \\
\hline Coluber constrictor \\
Pituophis melanoleucus \\
Crotalus viridis \\
Sceloporus graciosus \\
Uta stansburiana \\
Scaphiopus intermontanus \\
Bufo woodhouseii \\
Hyla regilla
\end{tabular}

In a study of habitat associations of herpetiles, Marr et al. (1988) found no lizards in the hopsage/Sandberg's bluegrass habitats, and approximately one third the abundance of snakes as was found in sagebrush/Sandberg's bluegrass or sagebrush/cheatgrass habitats. Snakes and lizards were captured at almost equal rates on a per-trap-night basis in the sagebrush habitats. The northern Pacific rattlesnake was captured only in the vicinity of talus slopes, near Gable Mountain. Northern sagebrush lizards (Sceloporus graciosus) were captured only in bitterbrush/Sandberg's bluegrass habitat.

The Great Basin spadefoot toad (Scaphiopus intermontanus) is limited in its distribution to the vicinity of riparian habitats, where it often frequents the nearby dry shrublands. It reproduces from May to June (Nussbaum et al. 1983). Cushing (1992) reports that Woodhouse's toad (Bufo woodhouseii) and the Pacific treefrog (Hyla regilla) are found near permanent water bodies and along the Columbia River.

\subsection{Terrestrial and Aquatic Invertebrates}

More than 300 terrestrial and aquatic insect species are found on the Hanford Site (ERDA 1975; Rogers 1979, Table 3.4). Insects and other related arthropod groups (mites and spiders) are ubiquitous within terrestrial habitats at the Hanford Site. However, they are not uniformly distributed across all habitats. The greatest numbers are associated with the bunchgrass community where most individuals occur either within the bunchgrass clumps or within the litter layer associated with shrubs, mostly sagebrush (Rickard et al. 1988).

The major taxonomic groupings, as indicated by biomass estimates, are coleoptera (beetles), hymenoptera (ants, bees, and wasps), and lepidoptera (moths and butterflies). Darkling beetles (tenebrionidae) and ground beetles (carabidae) are the most common beetles present. Ants (formicidae) comprise the most common hymenopter present, and moths comprise the most common lepidopterans. 
Table 3.4. Relative Abundance (\%) of Insect Taxa Collected from Sagebrush, Rabbitbrush, and Hopsage (Rogers 1979)

\begin{tabular}{lrrrr}
\multicolumn{1}{c}{ Taxa } & Sagebrush & Rabbitbrush & Hopsag \\
\cline { 1 - 1 } Hemiptera & & 44.6 & 11.7 & 6.4 \\
Homoptera & & 33.0 & 31.2 & 6.1 \\
Orthoptera & 7.3 & 24.0 & 21.8 \\
Araneida & 6.5 & 20.7 & 21.3 \\
Hymenoptera & 4.2 & 2.9 & 5.8 \\
Coleoptera & 1.7 & 1.9 & 27.4 \\
Lepidoptera & 1.2 & 6.1 & 5.3 \\
Diptera & 1.1 & 1.2 & 5.3 \\
Neuroptera & 0.3 & 0.3 & 0.3 \\
Other & 0.1 & 0.1 & 0.3
\end{tabular}

The abundance of beetles varies according to the season, elevation, and within different biotic communities. In general, beetles are most abundant at low elevations and least abundant at the highest elevations (Rickard 1970). While most species occur aboveground from early spring until fall, some, like the fall dwelling darkling beetles Philolithus densicollis and Stenomorpha puncticoliis, only occur aboveground during the period from September to December (Rogers and Rickard 1977). Darkling beetles are a dominant part of the insect community in Hanford habitats. Eighteen different species are known to inhabit the Site.

Cheatgrass communities appear to be less valuable as habitat for insects. Beetles and grasshoppers tend to be the dominant taxa and sometimes can be very abundant. For example the migratory grasshopper Melanoplus sanguinipes is occasionally very abundant in cheatgrass communities where peak abundance may reach 50/per square meter (Rogers and Uresk 1984). Seventeen different species of grasshoppers are known to inhabit the Site.

Sometimes insects become so abundant they completely defoliate shrubs or consume a significant portion of the total forage available to other consumers. They are also important sources of food for other higher level consumers and, therefore, help define sensitive hi itat areas for other species.

Benthic organisms are found either attached to or closely associated with the substratum in the river. All major freshwater benthic taxa are represented in the Columbia River, and insect larvae such as caddisflies (Trichoptera), midge flies (Chironomidae), and black flies (Simuliidae) are dominant. Dominant caddisfly species are Hydropsyche cockerelli, Cheumatopsyche campyla, and C. enonis. Peak larval insect densities are found in late fall and winter, and the major emergence is in spring and summer (Wolf 1976). Other benthic organisms include molluscs, sponges, and crayfish. Stomach contents of fish collected in the Hanford Reach from June 1973 through March 1980 revealed that benthic invertebrates are important food items for nearly all juvenile and adult fish. A close relationship also exists between food organisms in the stomach contents and those in the benthic and invertebrate drift communities. 
Two aquatic mollusc species of concern occur in the Hanford Reach of the Columbia River: the Columbia pebblesnail (Fluminicola columbiana) and the shortface lanx (Fisherola nuttalli). Both are federally listed candidate species, and both are state listed candidate species (Cushing 1992). The Hanford Reach contains a small population of the Columbia pebblesnail and a large population of the shortface lanx (Neitzel and Frest 1993). Both of these species occupy areas of the river with sufficient flow, oxygenation, and stable substratum even in the absence of rapids or whitewater areas. They are obligate perilithon grazers whose diet consists largely of diatoms and smaller epilithic and epiphytic algae. Both species are semelparous; longevity seldom exceeds 1 year.

One new land snail species was encountered during recent surveys of springs and streams on the Hanford Site (Frest and Johannes 1993). The species, Cryptomastix n. sp., was found at a single site and is most likely closely related to $C$. hendersonii, which is a taxon suggested as a candidate for listing as state threatened. Frest and Johannes (1993) suggest that the new Cryptomastix species should also be considered a probable candidate for listing and protection.

\subsection{Fisheries}

The Hanford Reach is the only remaining section of the mainstem Columbia River that supports healthy populations of fish species that are native to free-flowing aquatic systems. This is a direct result of the unique and diversified aquatic habitat found within the Reach. Over 43 species of fish have been documented in the Hanford Reach since 1943 (Gray and Dauble 1977). Native fish species of importance found in the Reach include fall chinook salmon (Oncorhynchus tshawytscha), steelhead trout (O. mykiss), mountain whitefish (Prosopium williamsoni), white sturgeon (Acipenser transmontanus), sandroller (Percopis transmontana), paiute sculpin (Cottus beldingi), and mountain sucker (Catostomus platyrhynchus). Coho $(O$. kisutch), sockeye $(O$. nerka), and other stocks of native chinook salmon migrate through the Hanford Reach. Other important non-native resident fish species include smallmouth bass (Micropterus dolomieui), largemouth bass (Micropterus salmoides), and walleye (Stizostedion vitreum).

Fisheries management within the Hanford Reach has focused on fall chinook salmon. This stock of fall chinook salmon is extremely valuable to the Columbia River tribal cultures, the ocean troll, and the recreational angler (Dauble and Watson 1990). Populations of fall chinook salmon within the Reach are sustained through artificial and natural production. The Hanford Reach provides the last section of the mainstem Columbia River where salmon are able to spawn. An annual census of fall chinook salmon spawning since 1948 indicates fall chinook salmon spawn throughout the entire Reach with over $60 \%$ of the spawning occurring at Vernita Bar and in the Locke Island area near the White Bluffs (Dauble and Watson 1990; Swan 1989, Figure 3.1). Water temperature, velocity and flow, substrate size, interstitial composition, and intergravel permeability all affect the distribution of salmon spawning (Chapman 1988). Backwater sloughs and shoreline embayments provide excellent foraging and rearing areas for juvenile salmon. 


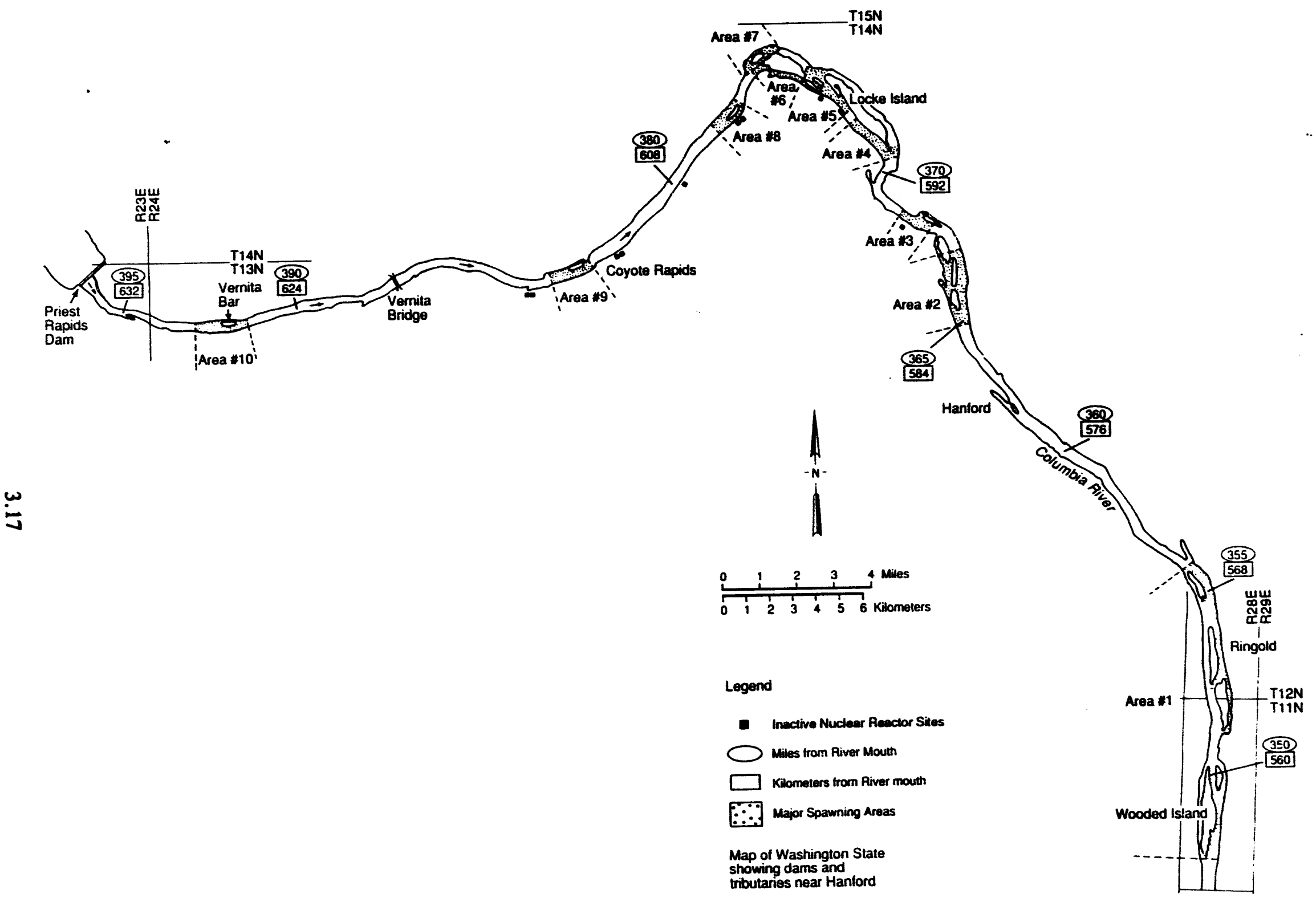

Figure 3.1. Major Fall Chinook Salmon Spawning Areas in the Hanford Reach of the Columbia River 
Although steelhead and chinook salmon have a similar life cycle, little is known about the quantity and quality of steelhead trout spawning, rearing, and adult holding habitat in the Hanford Reach (Watson 1973). Counts from 1972 to 1988 indicate that about 20,000 steelhead trout passed McNary Dam but did not pass Priest Rapids or Ice Harbor dams. Some of these fish enter the Yakima River while some are caught in the sport fishery. The remainder represent potential spawners. It appears a substantial number of steelhead terminate their migration in the Hanford Reach. Habitat requirements of steelhead trout are generally similar to those of fall chinook salmon.

Mountain whitefish depend on uniform flows, water depths of 1 to $2 \mathrm{~m}$, and substrate ranging in size from gravel to coarse rubble (Brown 1952). Adult whitefish appear to use habitat ranging from nearshore riffle areas to deep pools out of the main current. From October through January, large numbers of whitefish migrate upstream towards Priest Rapids Dam to spawn (Fickeisen et al. 1980a). Following emergence in early April and May, juvenile mountain whitefish are found in shallow near shore pools where there is a mix of mud and rubble substrate adjacent to areas off the main current. Although specific studies have not been done on Hanford Reach whitefish, probable habitat for this species most likely exists throughout the entire Reach (Fickeisen et al. 1980b).

Before the construction of hydropower dams on the Columbia River, white sturgeon most likely migrated into the upper reaches of the Columbia River into Canada to spawn. Dam operations in the Columbia River have changed the hydrological conditions necessary for successful egg incubation, rearing of young, and prey production (Coon et al. 1977). The Hanford Reach comprises the only significant remaining section of the inland Columbia River where white sturgeon are able to spawn (Mullan 1986). Sturgeon have been documented to use the entire Reach (Haynes et al. 1978). Although their habitat requirements within the Reach have not been studied specifically, probable spawning and rearing areas are dispersed throughout the entire Reach (Fickeisen et al. 1980a). White sturgeon provide a unique sport fishing opportunity within the Reach and most likely contribute to the commercial and recreational harvest downstream.

The sandroller is classified as a proposed monitor species in the state of Washington and is designated as a species of special concern because of its limited distribution (Johnson 1987). It is endemic to the Columbia River system, but is currently found only in limited areas including the Hanford Reach. Fish located at night were observed in shallow sand depressions at water deptlis of approximately $4 \mathrm{~m}$ (Gray and Dauble 1976). In other parts of its range it uses debris, tree roots, and under cut banks for cover in quiet backwaters during the day (Wydoski and Whitney 1979). Paiute sculpin and mountain sucker are also listed as species of special concern in the state of Washington (Johnson 1987). Both species are native to the Columbia River system and are found in the Hanford Reach.

Non-native resident fish of importance include smallmouth and largemouth bass. Of the two species, smallmouth bass are more abundant in the Hanford Reach. Smallmouth bass were introduced into the Yakima River system around 1925 and dispersed throughout the Hanford Reach (Fickeisen et al. 1980b). Adult smallmouth migrate long distances to spawn in the warm back waters of the Hanford Reach in the early summer. Juveniles are reared in these rich environments and feed on a diverse assemblage of insects and fish. A popular sport fishery exists for smallmouth bass in the Hanford Reach. Another non-native resident fish species found in the Hanford Reach is walleye. Although not as common as smallmouth bass, walleye are occasionally caught by anglers in the Hanford Reach. 


\subsection{Plant Species of Concern}

Twelve species of plants that exist on or are known to exist near the Hanford Site are of special concern (Sackschewsky 1992) (Table 4.1). Four of these species are currently candidates for federal protection under the Endangered Species Act: northern wormwood (Artemisia campestris ssp. borealis var. wormskioldii), persistent sepal (Columbia) yellowcress, Hoover's desert parsley, and Columbia milkvetch (Astragalus columbianus) (55 FR 6184-6229). At the state level, northern wormwood and Columbia yellowcress are listed as endangered, while Hoover's desert parsley and Columbia milkvetch are listed as threatened (Washington Natural Heritage Program 1990). Washington State lists eight plant species known to occur on Hanford as sensitive: gray cryptantha (Cryptantha leucophaea), bristly cryptantha (Cryptantha interrupta), Piper's daisy (Erigeron piperianus), dense sedge (Carex densa), shining flatsedge (Cyperus rivularis), southern mudwort (Limosella acaulis), false pimpernel (Lindernia anagallidea), and dwarf evening primrose (Oenothera pygmaea). None of these state-sensitive species are candidates for federal protection. The approximate locations of areas where populations of plant species of concern are known to occur are shown in Figure 4.1. This figure is not intended to represent all areas where species of concern might exist, but only shows general locations where plant populations are known.

\subsection{Riparian and Wetland Species}

Six of the 12 species of concern occur in wetland or riparian-zone habitats associated with the Columbia River: Columbia yellowcress, northern wormwood, dense sedge, shining flatsedge, false pimpernel, and southern mudwort.

Columbia yellowcress is found at a number of locations along the shoreline of the Columbia River (Sackschewsky 1992; Sauer and Leder 1985). This species is a perennial clonal species in the Brassicaceae family known from 11 sites in Washington and Oregon. The Hanford Reach is believed to support the largest known population of this rare species in Washington State. It grows in river gravels and cobbles, but can survive in sandy soils and in association with other plant species. Flat to gently sloping, cobbly, sandy substrate is the general habitat type. Because of its proximity to the water, this species often may be submerged when regulation of river flows by the upriver dams causes river levels to rise.

Northern wormwood has not been found on the Hanford Site, but one of the two known populations for this species occurs upstream within $25 \mathrm{~km}$ of Site boundaries. The habitat for this species is "non-wetland riparian" (Sackschewsky 1992). Plants usually occur on cobble/stony soils in association with a number of other species. This variety of northern wormwood appears quite similar to other varieties of Artemisia campestris, but plants are generally smaller. Most importantly, the wormskioldii variety flowers in April, while other wormwood varieties flower during the summer months. Cobble/gravel bars located along the Hanford Reach within Site boundaries appear to provide suitable habitat for this species. In cooperation with the Nature Conservancy, PNL staff conducted preliminary surveys of likely habitat during spring months of 1993, but did not identify any populations on the Site. Because of the rarity of this variety of wormwood and the large amount of suitable habitat along the shoreline and islands of the Columbia River, special emphasis should be given to ascertain its status on the Hanford Site. 
Table 4.1. Status of Plant Species of Concern on the Hanford Site

\begin{tabular}{|c|c|c|c|c|}
\hline Family & Common Name & Latin Name & Habitat Association & Status (a) \\
\hline \multirow[t]{2}{*}{ Brassicaceac } & Columbia yellowcress & Rorippa columbiae & Riparian, shoreline & FC, SE \\
\hline & Northern wormwood & $\begin{array}{l}\text { Artemisia campestris spp. } \\
\text { borealis var wormskioldii }\end{array}$ & $\begin{array}{l}\text { Riparian, } \\
\text { cobble/gravel bars }\end{array}$ & FC, SE \\
\hline Fabiacene & Columbia milkvetch & Astragalus columbianus & $\begin{array}{l}\text { Sagebrush-steppe, } \\
\text { basalt outcrops }\end{array}$ & FC, ST \\
\hline Apiaceae & Hoover's desert parsley & Lomatium tuberosum & $\begin{array}{l}\text { Basalt outcrops, } \\
\text { scree slopes }\end{array}$ & FC, ST \\
\hline Boraginaceae & Gray cryptantha & Cryptantha leucophaea & $\begin{array}{l}\text { Sagebrush-steppe } \\
\text { sandy soils }\end{array}$ & SS \\
\hline Boraginaceae & Bristly cryptantha & Cryptantha interrupta & Sagebrush-steppe & SS \\
\hline Cyperaceae & Dense sedge & Carex densa & Riparian, wetlands & SS \\
\hline Cyperaceae & Shining flatsedge & Cyperus rivularis & Riparian, wetlands & SS \\
\hline Asteraceae & Piper's daisy & Erigeron piperianus & Sagebrush-steppe & SS \\
\hline Scrophulariaceae & Southern mudwort & Limosella acaulis & Riparian, wetlands & sS \\
\hline Scrophulariaceae & False pimpernel & Lindernia anagallidea & Riparian, wetlands & SS \\
\hline Onagraceae & Dwarf evening primrose & Oenothera pygmaea & Sagebrush-steppe & SS \\
\hline
\end{tabular}

(a) $\quad$ FC $=$ Federal candidate.

SE $=$ State endangered.

ST $=$ State threatened.

SS $=$ State sensitive.

Dense sedge has been reported and shining flatsedge has been found in wetland habitats in the vicinity of the $100 \mathrm{~B}$ and $\mathrm{C}$ Areas. Suitable habitat may exist at other locations along the Columbia River banks in wet, marshy areas and wetlands. False pimpernel has been found in wetlands adjacent to the 100 Areas, and suitable habitat is available at other locations on the river. The southern mudwort grows in shallow water or wet mud along the Columbia near the 100 Areas. This species flowers in August or September and may be located in other suitable habitat areas along the river.

\subsection{Upland Plant Species}

Of the six plant species of concern that are not associated with riparian habitat, only four are known to be located within Hanford Site boundaries. These species occur in several different habitat types on different soils.

Columbia milkvetch is found on Umtanum Ridge and near the Midway power substation. This species was believed to be extinct before it was relocated 15 years ago near Hanford on the U.S. Army's Yakima Training Center. It is most often found on stony or sandy soils in association with 


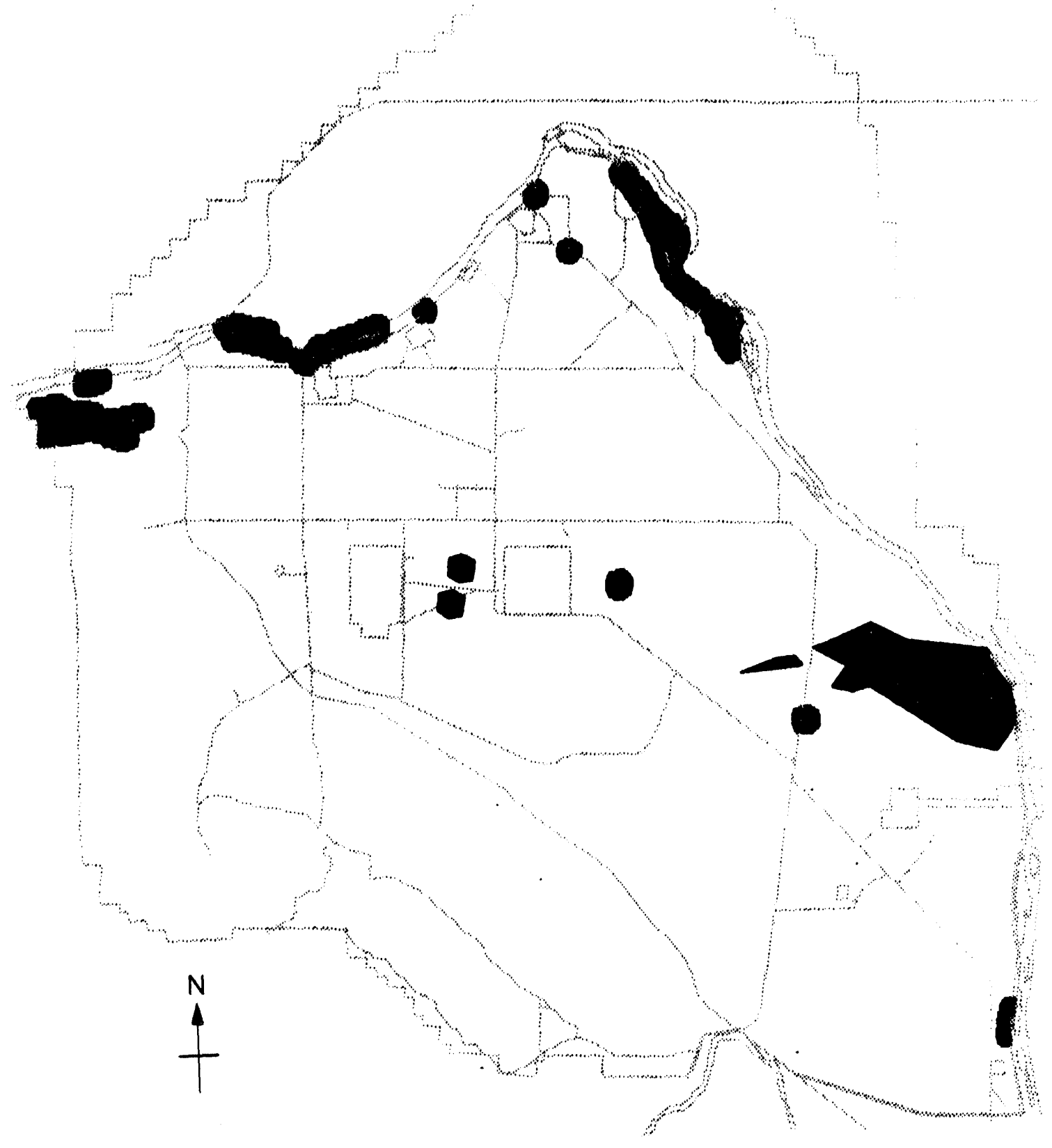

Figure 4.1. Locations of Plant Populations of Concern on the Hanford Site (Preliminary map) 
sagebrush, and flowers in early April. Hoover's desert parsley also is found on Umtanum Ridge near the Midway substation. This desert parsley prefers scree slopes as a habitat and usually blooms in March and April.

Piper's daisy has been found in both sagebrush-steppe on the Columbia River Plain and in sagebrush-steppe at higher elevations. This species has been found in association with several disturbed areas on the site as well, but is most usually found in undisturbed, sagebrush-steppe growing on sandy soils. This species normally flowers during May. Gray cryptantha is found in sand dune habitat types growing in association with buckwheat, bitterbrush, and needle and thread grass. This perennial forb is a member of the Boraginaceae family and usually flowers in April and May.

Bristly cryptantha, another member of the Boraginaceae family, has been found across the Columbia River near the White Bluffs. The proximity of this population of a state-sensitive species requires that we consider it as potential inhabitant of the Hanford Site. The dwarf evening primrose has been found in two disturbed gravel pits on the Columbia River Plain. This is an annual species in the Onagraceae that flowers in late May and June. It is likely that it also occurs in non-disturbed areas on the Hanford Site. 


\subsection{Potential Areas of Sensitive or Critical Habitat}

The wildlife and plant species of concern that inhabit the Hanford Site range across several of the primary habitat types discussed in previous sections. Areas of sensitive or critical habitat for a particular species include those areas required to maintain healthy breeding or reproducing populations of that particular plant or animal species. Because the biota and the biologic processes associated with them are dynamic, sensitive or critical habitat areas on the Hanford Site may also be dynamic, changing as species distributions change or as seasons change. Determining whether a particular area provides sensitive or critical habitat for a species is predicated on understanding both the natural history of a species and its habitat requirements.

Within each description of a habitat type, we have briefly described the important wildlife and plant species that rely on that particular habitat. Tabular information provided in Sections 3.0 and 4.0 lists preferred habitat types for wildlife species and the vegetation associations in which sensitive plant species are located. Some of this information is summarized here. However, in any assessment of habitat for a particular species, an in-depth review of species habitat requirements, distribution, and seasonality should be conducted.

Of the habitat types identified in this document, two are particularly sensitive in terms of wildlife and plant species of concern: riparian areas and shrub-steppe stands on the Columbia River Plain. Other areas of habitat on the Site may also be sensitive depending on the species being considered and the time of year.

Riparian zones associated with the Columbia River and streams and springs are highly diverse. Both permanent and ephemeral stream/spring riparian areas on the site are potentially sensitive areas still being surveyed for the presence of sensitive mollusc species. These streams, springs, and seeps also provide an important water source for terrestrial species. The riverine/riparian zone along the Columbia River is potentially sensitive because they may contain: 1) wetlands and the associated plant species of concern, 2) wintering bald eagle roosting and perching areas, 3) Columbia yellowcress along the wetted shoreline of the river and the potential for the occurrence of northern wormwood on the cobbly substrate of the bars and islands in the river, and 4) a large number of shore birds that are of potential concern (see Table 3.1) and waterfowl that use the Hanford Reach, including the American white pelican (Pelecanus erythrorhynchos), great blue heron, and sandhill crane (Grus canadensis).

The remaining shrub-steppe habitat on the Columbia River Plain is a potentially sensitive habitat area because it provides critical nesting habitat for the loggerhead shrike (Appendix A, Figure A.1), sage sparrow, and sage thrasher. Other bird species of concern that inhabit shrub-steppe include the burrowing owl, ferruginous hawk, golden eagle, grasshopper sparrow, long-billed curlew, northern goshawk, prairie falcon, sandhill crane, snowy owl, and Swainson's hawk. Several of the preceding species also require the adjacent riverine habitat provided by the Hanford Reach. The old-growth shrub-steppe on the plain may become a more critical element for wildlife as the amount of shrubsteppe habitat within Washington State continues to decline through agricultural, industrial and urban development. 
Sand dunes and blowouts are a sensitive habitat type because some of them harbor plant species of concern on the Hanford Site. Although complete surveys of the dunes for gray cryptantha have not been conducted, it is likely that this species is distributed across the sand dune habitat type.

Basalt outcrops and scree slopes provide preferred habitat for protected plant species such as Hoover's desert parsley. The shrub-steppe surrounding basalt outcrops may also support sensitive flora, as is the case on Umtanum Ridge above Juniper Springs where several plant species of concern occur.

One potentially sensitive habitat area on the Hanford Site is not associated with any particular vegetation association. During the past 5 years, ferruginous hawks on the Hanford Site have nested on towers supporting power transmission lines. The habitat in the areas surrounding these towers that support nests is sensitive during the months of March to September when ferruginous hawks inhabit the areas. 


\subsection{References}

40 CFR 300. "EPA National Oil and Hazardous Substances Pollution Contingency Plan Under the Comprehensive Environmental Response, Compensation, and Liability Act of 1980." U.S. Code of Federal Regulations.

56 FR 58804-58836. November 21, 1991. U.S. Department of the Interior, Fish and Wildlife Service, "Endangered and Threatened Wildlife and Plants; Animal Candidate Review for Listing as Endangered or Threatened Species, Proposed Rule." Federal Register.

56 FR 6184-6229. February 21, 1990. U.S. Department of the Interior, Fish and Wildlife Service, "Endangered and Threatened Wildlife and P!ant Taxa for Listing as Endangered or Threatened Species, Notice of Review." Federal Register.

Allen, J. N. 1980. "The Ecology and Behavior of the Long-Billed Curlew in Southeastern Washington." Wildlife Monograph 73, The Wildlife Society, Bethesda, Maryland.

Armitage, K. B. 1979. "Food Selectivity by Yellow-Bellied Marmots." J. Mamm. 60:628-629.

Books, G. G. 1984. Avian Community Interactions with Mid-Columbia River Water Level Fluctuations: Resource Use and Species Inventory. M.S. Thesis, Washington State University, Pullman, Washington.

Brandt, C. A., W. H. Rickard, and M. G. Hefty. 1990. Interim Reclamation Report Basalt Waste Isolation Project Boreholes 1989. PNL-7280, Pacific Northwest Laboratory, Richland, Washington.

Brandt, C. A., W. H. Rickard, and N. A. Cadoret. 1991. Reclamation Report Basalt Waste Isolation Project Boreholes 1990. PNL-7585, Pacific Northwest Laboratory, Richland, Washington.

Brandt, C. A., and W. H. Rickard. 1992. "Effects of Survey Frequency on Bird Density Estimates in the Shrub-Steppe Environment." Northwest Sci. 66:172-182.

Brown, C. 1952. "Spawning Habits and Early Development of the Mountain Whitefish, Prosopium williamsoni, in Montana." Copeia 2:109-113.

Chapman, D. W. 1988. "Critical Review of Variables Used to Define Effects of Fines in Redds of Large Salmonids." Transactions of the American Fisheries Society 117:1-21.

Coon, J. C., R. R. Ringe, and T. C. Bjornn. 1977. "Abundance, Growth, Distribution, and Movements of White Sturgeon in the Mid-Snake River." Contribution No. 97, Forest, Wildlife, and Range Experiment Station. University of Idaiıo, Moscow, Idaho.

Crabtree, R. L. 1989. Sociodemography of an Unexploited Coyote Population. Ph.D. Dissertation, University of Idaho, Moscow, Idaho. 
Cushing, C. E. (ed). 1992. Hanford Site National Environmental Policy Act (NEPA)

Characterization. PNL-6415, Rev. 5, Pacific Northwest Laboratory, Richland, Washington.

Cushing, C. E., and E. G. Wolf. 1984. "Primary Production in Rattlesnake Springs, a Cold Desert Spring-Stream." Hydrobiologia 114:229-236.

Daubenmire, R. 1970. Steppe Vegetation of Washington. Technical Bulletin 62, Experimental Station, Washington State University, Pullman, Washington.

Dauble, D. D., and D. G. Watson. 1990. Spawning and Abundance of Fall Chinook Salmon (Oncorhynchus tshawytscha) in the Hanford Reach of the Columbia River, 1948-1988. PNL-7289, Pacific Northwest Laboratory, Richland, Washington.

Eberhardt, L. E., R. G. Anthony, and W. H. Rickard. 1989. "Movement and Habitat Use by Great Basin Canada Goose Broods." J. Wildlife Management 53:740-748.

Eberhardt, L. E., E. E. Hanson, and L. L. Cadwell. 1982. Analysis of Radionuclide Concentrations and Movement Patterns of Hanford Site Mule Deer. PNL-4420, Pacific Northwest Laboratory, Richland, Washington.

Eisner, S. A. 1991. Bald Eagles Wintering Along the Columbia River in Southcentral Washington; Factors Influencing Distribution and Characteristics of Perch and Roost Trees. Master's Thesis, University of Montana, Missoula, Montana.

Energy Research and Development Administration (ERDA). 1975. Final Environmental Statement, Waste Management Operations. ERDA-1538, Vol. 1, Energy Research and Development Administration, Richland, Washington.

Fickeisen, D. H., D. D. Dauble, D. A. Neitzel, W. H. Rickard, R. L. Skaggs, and J. L. Warren. 1980a. Aquatic and Riparian Resource Study of the Hanford Reach, Columbia River, Washington. Prepared for the U.S. Army Corps of Engineers, Seattle District, Washington by Battelle, Pacific Northwest Laboratories, Richland, Washington.

Fickeisen, D. H., R. E. Fitzner, R. H. Sauer, and J. L. Warren. 1980b. Wildlife Usage, Threatened and Endangered Species and Habitat Studies of the Hanford Reach, Columbia River, Washington. Prepared for the U.S. Army Corps of Engineers, Seattle District, Washington by Battelle, Pacific Northwest Laboratories, Richland, Washington.

Fitzner, R. E. 1980. Behavioral Ecology of the Swainson's Hawk (Buteo swainsoni) in Washington. PNL-2754, Pacific Northwest Laboratory, Richland, Washington.

Fitzner, R. E., and R. H. Gray. 1991. "The Status, Distribution and Ecology of Wildlife on the U.S. DOE Hanford Site: A Historical Overview of Research Activities." Environ. Monit. Assess. 18:173-202. 
Fitzner, R. E., and W. C. Hanson. 1979. "A Congregation of Wintering Bald Eagles." Condor 81:311-313.

Fitzner, R. E., and R. L. Newell. i989. "Ferruginous Hawk Nesting on the U.S. DOE Hanford Site: A Recent Invasion Following an Introduction of Transmission Lines." In Issues and Technology in the Management of Impacted Western Wildlife, Proceedings of a National Symposium, Thorne Ecological Institute, February 6-8, 1989, Glenwood Springs, Colorado.

Fitzner, R. E., and W. H. Rickard. 1975. Avifauna of Waste Ponds ERDA Hanford Reservation Benton County, Washington. BNWL-1885, Pacific Northwest Laboratory, Richland, Washington.

Fitzner, R. E., and S. G. Weiss. 1992. Bald Eagle Site Management Plan for the Hanford Site, South Central Washington. WHC-EP-0510, Westinghouse Hanford Company, Richland, Washington.

Fitzner, R. E., K. A. Gano, W. H. Rickard, and L. E. Rogers. 1979. Characterization of the Hanford 300 Area Burial Grounds. Task IV-Biological Transport. PNL-2774, Pacific Northwest Laboratory, Richland, Washington.

Fitzner, R. E., W. H. Rickard, L. L. Cadwell, and L. E. Rogers. 1981. Raptors of the Hanford Site and Nearby Areas of South Central Washington. PNL-3212, Pacific Northwest Laboratory, Richland, Washington.

Fitzner, R. E., S. G. Weiss, and J. A. Stegen. 1992. Biological Assessment for Threatened and Endangered Wildlife Species Related to CERCLA Characterization Activities. WHC-EP-0513, Westinghouse Hanford Company, Richland, Washington.

Flux, J.E.C., and R. Angermann. 1990. "The Hares and Jackrabbits." In Rabbits, Hares and Pikas, J. A. Chapman and J.E.C. Flux, eds., pp. 61-94. IUCN, Gland, Switzerland.

Frase, B. A., and R. S. Hoffmann. 1980. "Marmota flaviventris." Mammalian Species 135:1-8.

Frest, T. J., and E. J. Johannes. 1993. Mollusc Survey of the Hanford Site, Benton and Franklin Counties, Washington. PNL-8653, Pacific Northwest Laboratory, Richland, Washington.

Gano, K. A. and W. H. Rickard. 1982. "Small Mammals of a Bitterbrush-Cheatgrass Community." Northwest Sci. 56:1-7.

Gray, R. H., and D. D. Dauble. 1976. "New Distribution Records and Notes on the Life-History and Behaviour of the Sand Roller, Percopsis transmontana (Eigenmann and Eigenmann)." Syesis 9:369-370.

Gray, R. H., and D. D. Dauble. 1977. "Checklist and Relative Abundance of Fish Species from the Hanford Reach of the Columbia River." Northwest Science 51:208-215.

Gray, R. H., and W. H. Rickard. 1989. "The Protected Area of Hanford as a Refugium for Nature Plants and Animals." Environ. Conser. 16:251-260. 
Hall, E. R. 1946. Mammals of Nevada. University of California Press, Berkeley, California.

Hajek, B. F. 1966. Soil Survey: Hanford Project in Benton County, Washington. BNWL-243, Pacific Northwest Laboratory, Richland, Washington.

Hanson, W. C., and L. L. Eberhardt. 1971. A Columbia River Canada Goose Population, 195-1970. BNWL-1606, Pacific Northwest Laboratory, Richland, Washington.

Haynes, J. M., R. H. Gray, and J. C. Montgomery. 1978. "Seasonal Movements of White Sturgeon (Acipenser transmontanus) in the Mid-Columbia River." Transactions of the American Fisheries Society 107:275-280.

Hedlund, J. D., and L. E. Rogers. 1976. Characierization of Small Mammal Populations Inhabiting the B-C Crib Environs. BNWL-2181, Pacific Northwest Laboratory, Richland, Washington.

Hedlund, J. D., D. T. McCullough, and W. H. Rickard. 1975. "Mouse Populations on Knob and Kettle Topography in South-Central Washington." Northwest Sci. 49:253-260.

Hill, E. P. 1982. "Beaver." In Wild Mammals of North America, J. A. Chapman and G. A. Feldhamer, eds., pp. 256-281. Johns Hopkins University Press, Baltimore, Maryland.

Howard, R. P., and M. L. Wolfe. 1976. "Range Improvement Practices and Ferruginous Hawks." J. Range Manage. 29:33-37.

James, T. R. 1967. The Ecology and Life History of the White-Tailed Jack Rabbit Repus townsendii companium Hollister) in North Dakota. Ph.D. Thesis, University of North Dakota, Grand Forks, North Dakota.

James, W. B., and E. S. Booth. 1952. "Biology and Life History of the Sagebrush Vole." Walla Walla College Publishing, Dept. Biol. Sci. 1:23-43.

Jameson, E. W., and H. J. Peters. 1988. California Mammals. University of California Press, Berkeley, California.

Johnson, M. K. 1975. Interspecific Associations of Peromyscus maniculatus, Perognathus parvus, and Spe.mophilus townsendii on the Arid Land Ecology Reserve Examined by Diet Overlap and Related Data. BNWL-1929, Pacific Northwest Laboratory, Richland, Washington.

Johnson, J. E. 1987. Protected Fishes of the United States and Canada. American Fisheries Society, Bethesda, Maryland.

Kaufmann, J. H. 1982. "Raccoon and Allies." In Wild Mammals of North America, J. A. Chapman and G. A. Feldhamer, eds., pp. 567-585. Johns Hopkins University Press, Baltimore, Maryland.

Kunz, T. H. 1982. "Lasionycteris noctivagans." Mammalian Species 172:1-5. 
Landeen, D. S., A. R. Johnson, and R. M. Mitchell. 1992. Status of Birds at the Hanford Site in Southeastern Washington. WHC-EP-0402, Revision 1, Westinghouse Hanford Company, Richland, Washington.

Lundstrom, D. L. 1988. Foraging and Nesting Biology of Nuttall's Poorwill (Phalaenoptilus nuttalli) and Common Nighthawk (Chordeiles minor) in Southeastern Washington State. M.S. Thesis, Washington State University, Pullman, Washington.

Mack, R. N., and D. A. Pyke. 1983. "The Demography of Bromus tectorum: Variation in Time and Space." J. Ecology 71:69-93.

Marr, N. V., C. A. Brandt, R. E. Fitzner, and L. D. Poole. 1988. Habitat Associations of Vertebrate Prey Within the Controlled Area Study Zone. PNL-6495, Pacific Northwest Laboratory, Richland, Washington.

Messick, J. P., and M. G. Hornocker. 1981. "Ecology of the Badger in Southwestern Idaho." Wildlife Monograph 76, The Wildlife Society, Bethesda, Maryland.

Mullan, J. W. 1986. Status and Propagation of Chinook Salmon in the Mid-Columbia River Through 1985. U.S. Department of Interior, Fish and Wildlife Service, Washington, D.C.

Neitzel, D. A., and T. J. Frest. 1993. Survey of Columbia River Basin Streams for Columbia Pebblesnail (Fluminicola columbiana) and Shortface Lanx (Fisherola nuttalli). PNL-8229, Revision 1, Pacific Northwest Laboratory, Richland, Washington.

Nussbaum, R. A., E. D. Brodie, Jr., and R. M. Storm. 1983. Amphibians and Reptiles of the Pacific Northwest. University of Idaho Press, Moscow, Idaho.

O'Farrell, T. P. 1972. "Ecological Distribution of Sagebrush voles, Lagurus curtatus, in Southcentral Washington." J. Mammal. 53:632-636.

O'Farrell, T. P. 1975. "Small Mammals, Their Parasites and Pathologic Lesions on the Arid Lands Ecology Reserve, Benton County, Washington." Am. Midl. Nat. 93:377-387.

O'Farrell, T. P., R. J. Olson, R. O. Gilbert, and J. D. Hedlund. 1975. "A Population of Great Basin Pocket Mice, Perognathus parvus, in the Shrub-Steppe of South-Central Washington." Ecol. Monogr. 45:1-28.

Poole, L. D. 1992. Reproductive Success and Nesting Habitat of Loggerhead Shrikes in Shrubsteppe Communities. M.S. Thesis, Oregon State University, Corvallis, Oregon.

Rickard, W. H. 1965. "Sodium and Potassium Accumulation by Greasewood and Hopsage, Leaves." Botan. Gaz. 126:116-119.

Rickard, W. H. 1968. "Field Observations on the Altitudinal Distribution of the Side-Blotched Lizard." Northwest Sci. 42:161-164. 
Rickard, W. H. 1970. "The Distribution of Ground Dwelling Beetles in Relation to Vegetation Season and Topography in the Rattlesnake Hills, Southeastern Washington." Northwest Sci. 44:107113.

Rickard, W. H. 1988. Natural Vegetation at the Proposed Reference Repository Location in Southeastern Washington. PNL-6402, Pacific Northwest Laboratory, Richland, Washington.

Rickard, W. H., and U. C. McShane. 1984. "Demise of Spiny Hopsage Following Summer Wildfire: An Authentic Record." Northwest Sci. 58(4):282-285.

Rickard, W. H., and L. D. Poole. 1989. "Terrestrial Wildlife of the Hanford Site: Past and Future." Northwest Sci. 63:183-193.

Rickard, W. H., and L. E. Rogers. 1983. "Industrial Land Use and the Conservation of Native Biota in the Shrub-Steppe Region of Western North American." Environ. Conserv. 10:205-211.

Rickard, W. H., and D. A. Watson. 1985. "Four Decades of Environmental Change and Their Influence Upon Native Wildlife and Fish on the Mid-Columbia River, Washington, U.S.A."

Environ. Conserv. 12:241-248.

Rickard, W. H., J. D. Hedlund, and R. G. Schreckhise. 1974. Mammals of the Hanford Reservation in Relation to Management of Radioactive Waste. BNWL-1877, Pacific Northwest Laboratory, Richland, Washington.

Rickard, W. H., R. E. Fitzner, and C. E. Cushing. 1981. "Biological Colonization of an Industrial Pond." Environ. Conserv. 8:241-247.

Rickard, W. H., W. C. Hanson, and R. E. Fitzner. 1982. "The Non-Fisheries Biological Resources of the Hanford Reach of the Columbia River." Northwest Sci. 56:62-76.

Rickard, W. H., L. E. Rogers, B. E. Vaughan, and S. F. Liebetrau. 1988. Shrub-Steppe: Balance and Change in a Semi-Arid Terrestrial Ecosystem. Elsevier, New York.

Rickard, W. H., R. E. Fitzner, and C. A. Brandt. 1990. Biota of the 300-FF-1 Operable Unit. EMO-1016, Environmental Management Operations, Richland, Washington.

Rogers, L. E. 1979. Shrub Inhabiting Insects of the 200 Area Plateau, Southcentral Washington. PNL-2713, Pacific Northwest Laboratory, Richland, Washington.

Rogers, L. E., and K. A. Gano. 1980. "Townsend Ground Squirrel Diets in the Shrub-Steppe of South Central Washington." J. Range Manage. 33:463-465.

Rogers, L. E., and W. H. Rickard. 1977. Ecology of the 200 Area Plateau Waste Management Environs: A Status Report. PNL-2253, Pacific Northwest Laboratory, Richland, Washington. 
Rogers, L. E., and D. W. Uresk. 1984. "Food Plant Selection by the Migratory Grasshopper (Melanoplus sanguinipes) Within a Cheatgrass Community." Northwest Sci. 48(4):230-234.

Rotenberry, J. T. 1980. "Dietary Relationships Among Shrubsteppe Passerine Birds: Competition or Opportunism In A Variable Environment?" Ecol. Monogr. 50:93-110.

Rotenberry, J. T., R. E. Fitzner, and W. H. Rickard. 1979. "Seasonal Variation in Action Community Structure: Differences in Mechanisms Regulating Diversity." Auk 96:499-5055.

Sackschwesky, M. R. 1992. Biological Assessment. WHC-EP-524, Westinghouse Hanford Company, Richland, Washington.

Sackschwesky, M. R., and D. S. Landeen. 1992. Fiscal Year 1991100 Areas CERCLA Ecological Investigations. WHC-EP-0448, Westinghouse Hanford Company, Richland, Washington.

Sackschwesky, M. R., D. S. Landeen, G. I. Baird, W. H. Rickard, and J. L. Downs. 1992. Vascular Plants of the Hanford Site. WHC-EP-0554, Westinghouse Hanford Company, Richland, Washington.

Sauer, R. H., and J. E. Leder. 1985. The Status of Persistentsepal Yellowcress in Washington. Northwest Sci. 59(3):198-203.

Schuler, C. A., W. H. Rickard, and G. A. Sargeant. 1988. Bird Associations with Shrubsteppe Plant Communities at the Proposed Reference Repository Location in Southeastern Washington. PNL-6493, Pacific Northwest Laboratory, Richland, Washington.

Stegen, J. A. 1992. Biological Assessment for State Candidate and Monitor Wildlife Species Related to CERCLA. WHC-SD-EN-EE-009, Westinghouse Hanford Company, Richland, Washington.

Steigers, W. D., Jr., and J. T. Flinders. 1980. "Mortality and Movements of Mule Deer Fawns in Washington." J. Wildl. Manage. 44:381-388.

Stoel, P. F. 1976. Some Coyote Food Habit Patterns in the Shrub-Steppe of South-Central Washington. M.S. Thesis, Portland State University, Portland, Oregon.

Svendsen, G. E. 1982. "Weasels." In Wild Mammals of North America, J. A. Chapman and G. A. Feldhamer, eds., pp. 613-628. Johns Hopkins University Press, Baltimore, Maryland.

Swan, G. A. 1989. "Chinook Salmon Spawning Surveys in Deep Waters of a Large, Regulated River." Regulated Rivers: Research and Management 4:355-370.

Terres, J. K. 1980. The Audubon Society Encyclopedia of North American Birds. Alfred A. Knopf, New York.

Thiede, M. E. 1992. Small Mammals and Harvester Ants in the 300-FF-1 Operable Unit. WHCSD-EN-T1-026, Westinghouse Hanford Company, Richland, Washington. 
Thomas, J. W. 1979. Wildlife Habitats in Managed Forests: The Blue Mountains of Oregon and Washington. Agriculture Handbook No. 553, U.S. Department of Agriculture, Forest Service.

Thorp, J. M., and W. T. Hinds. 1977. Microclimates of the Arid Lands Ecology Reserve 1968-1975. BNWL-SA-6231, Pacific Northwest Laboratory, Richland, Washington.

U.S. Army Corps of Engineers. 1976. Inventory of Riparian Habitats and Associated Wildlife Along Columbia and Snake Rivers. Vol. 1, John L. McKern, Fish and Wildlife Biologist, Walla Walla District, U.S. Army Corps of Engineers, Vol. 4a, 4b, College of Forest Resources, University of Washington, Seattle, Washington. Sponsored by the U.S. Army Corps of Engineers, Pacific Northwest Division.

U.S. Department of Energy (DOE). 1993a. Hanford Site Baseline Risk Assessment Methodology. DOE/RL-91-45, Rev. 2, U.S. Department of Energy, Richland, Washington.

U.S. Department of Energy (DOE). 1993b. Columbia River Impact Evaluation Plan. DOE/RL-9228, Rev. 0, U.S. Department of Energy, Richland, Washington.

Uresk, D. W., and V. A. Uresk. 1980. Diets and Habitat Analyses of Mule Deer on the 200 Areas of the Hanford Site in South Central Washington. PNL-2461, Pacific Northwest Laboratory, Richland, Washington.

Uresk, D. W., J. F. Cline, and W. H. Rickard. 1975. Diets of Black-Tailed Hares on the Hanford Reservation. BNWL-1931, Pacific Northwest Laboratory, Richland, Washington.

Washington Department of Wildlife (WDW). 1993. Status of the Pygmy Rabbit (Brachylagus idahoensis) in Washington. Washington Department of Wildlife, Olympia, Washington.

Watson, D. G. 1973. Estimate of Steelhead Trout Spawning in the Hanford Reach of the Columbia River. Prepared for the U.S. Army Corps of Engineers under Contract DACW67-72-C-0100 by Battelle, Pacific Northwest Laboratories, Richland, Washington.

Weiss, S. G., and R. M. Mitchell. 1992. A Synthesis of Ecological Data from the 100 Areas of the Hanford Site. WHC-EP-0601, Westinghouse Hanford Company, Richland, Washington.

Wolf, E. G. 1976. "Characterization of the Benthos Community." In Final Report on Aquatic Ecological Studies Conducted at the Hanford Generating Project. Prepared for Washington Public Power Supply System under Contract No. 2311201335 to United Engineers and Constructors, Inc., by Battelle, Pacific Northwest Laboratories, Richland, Washington.

Wydoski, R. S., and R. R. Whitney. 1979. Inland Fishes of Washington. University of Washington Press, Seattle, Washington. 


\section{Appendix A}

Locations of Selected Species of Concern on the Hanford Site 


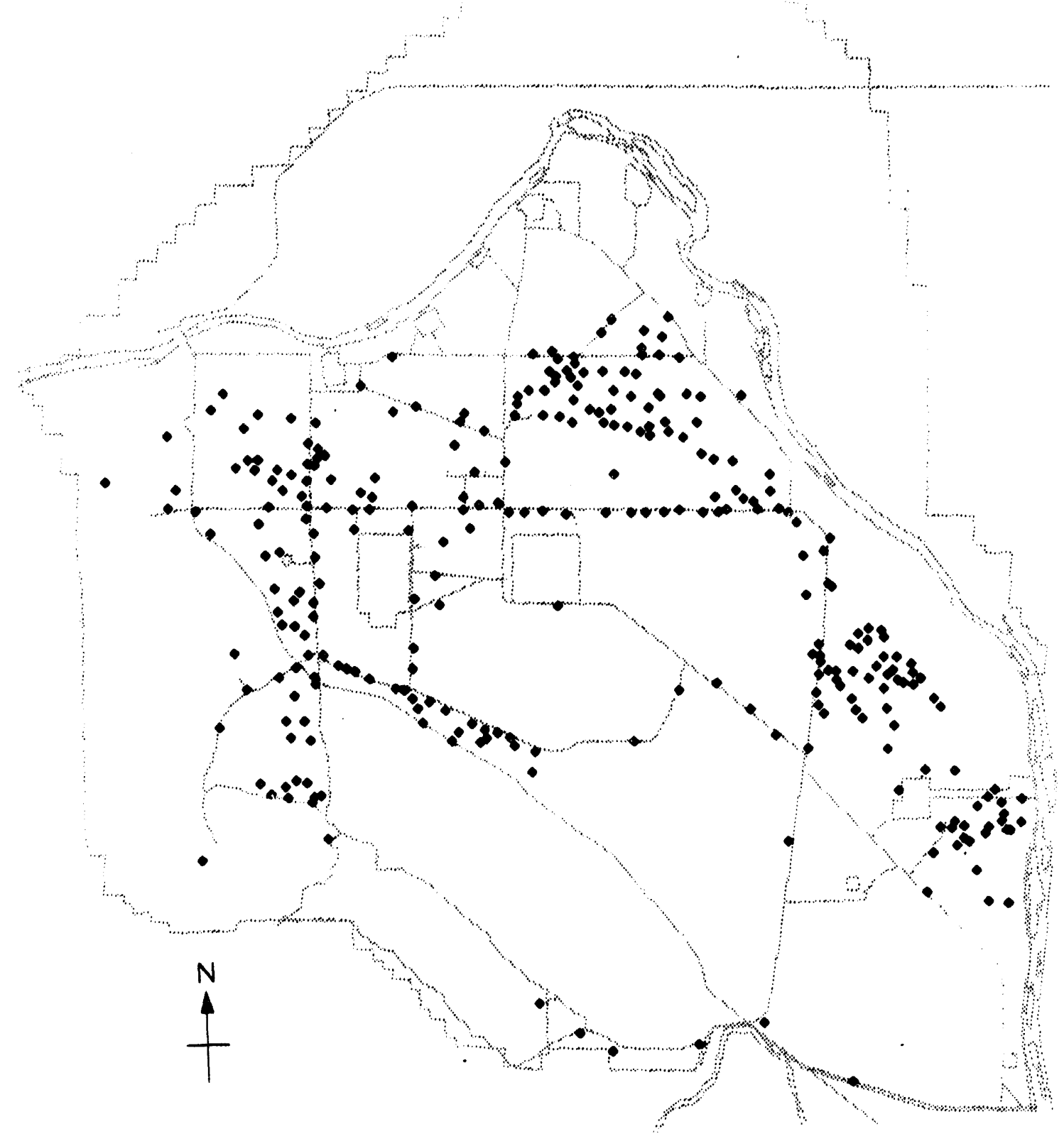

Figure A.1. Previously Recorded Loggerhead Shrike Nest Locations on the Hanford Site (Poole 1992) 


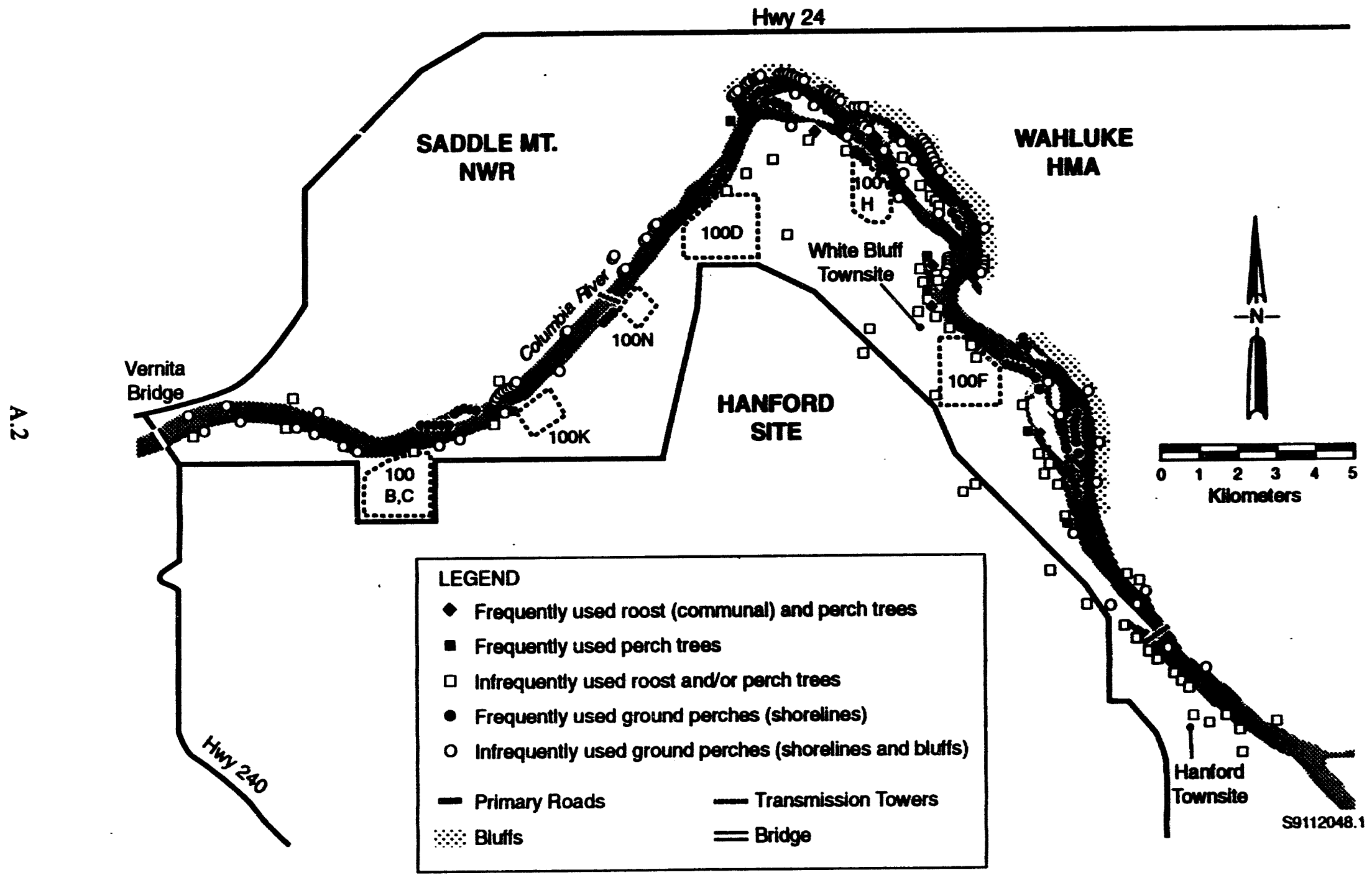

Figure A.2. Known Bald Eagle Roosting Sites on the Hanford Site (Eisner 1991) 


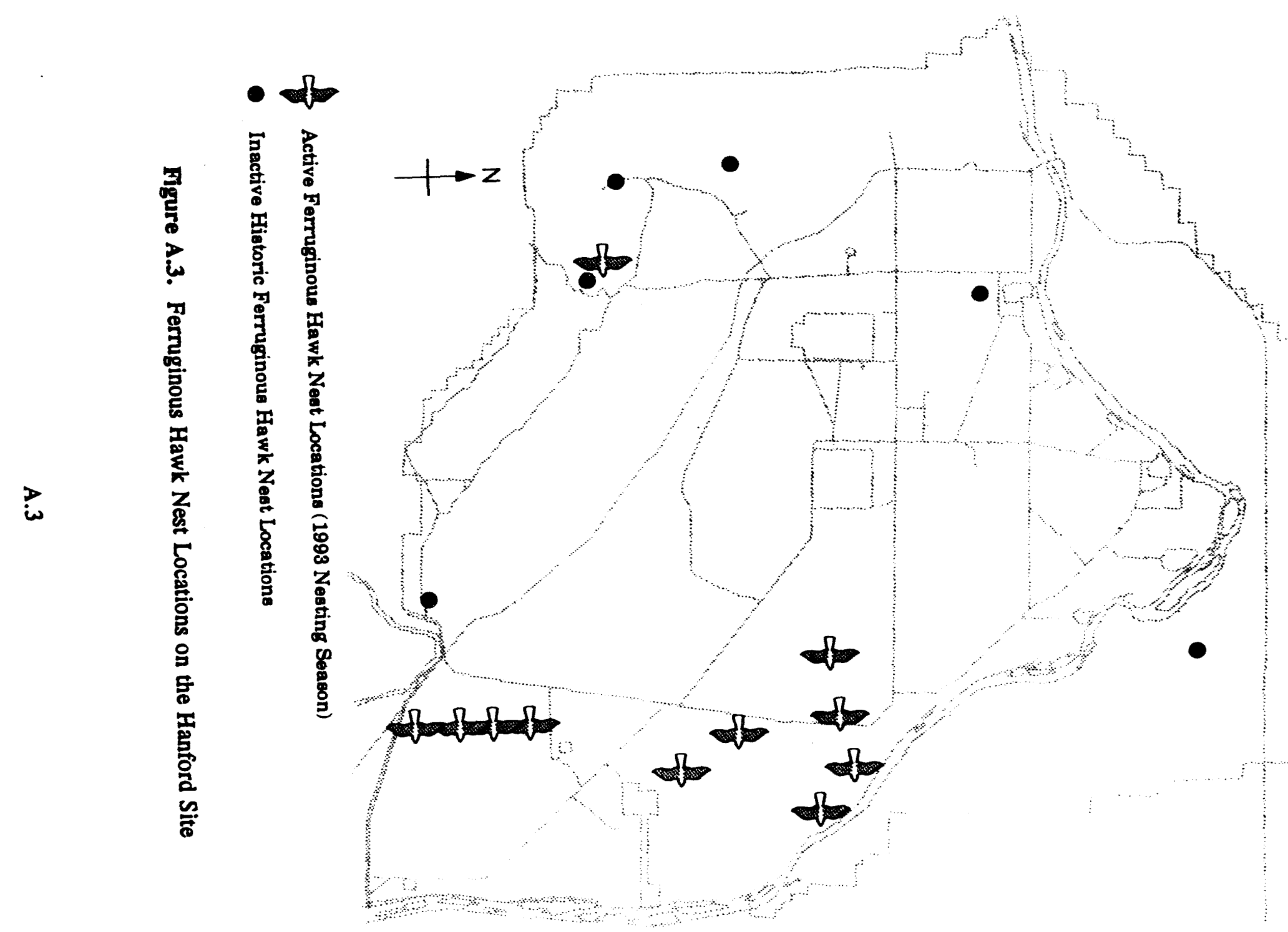




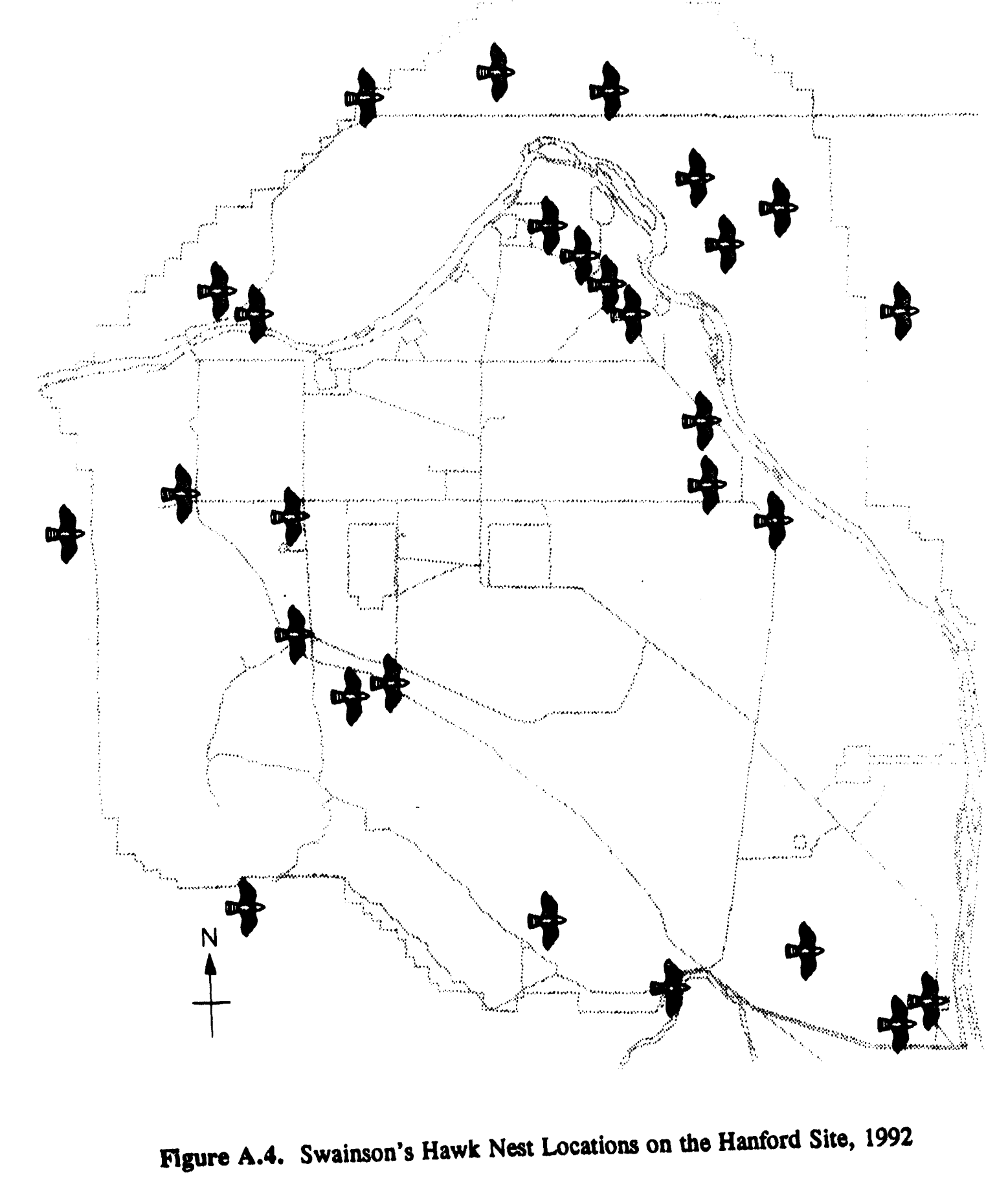




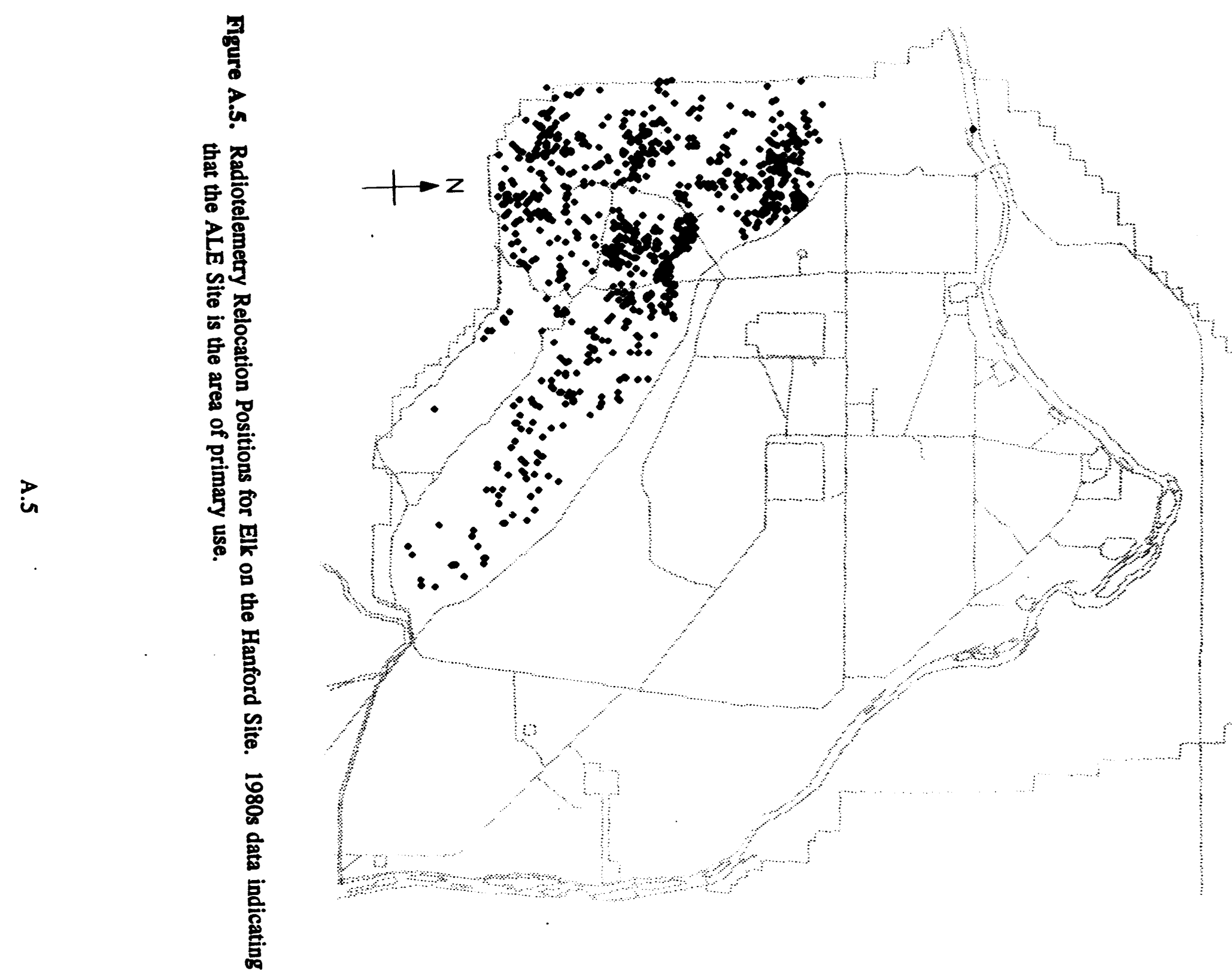




\section{Distribution}

No. of

Copies

\section{OFFSITE}

12 DOE Office of Scientific and Technical Information

3 Confederated Tribes and Bands of the Yakima Inoiian Nation

P.O. Box 151

Toppenish, WA 98948

ATTN: B. Cook

J. Bauer

R. Tulee

3 Confederated Tribes of the Umatilla Indian Reservation

P.O. Box 638

Pendleton, OR 97801

ATTN: A. Childs

T. Gilmore

J. R. Wilkinson

S. Cross

Washington State Department of Ecology

P.O. Box 47600

Olympia, WA 98504

D. Dunning

Oregon Department of Energy

625 Marion Street NE

Salem, OR 97310

L. Fitzner

Washington Department of Wildlife Lower River Road

Benton City, WA 99320

A. Foote

U.S. Army Corps of Engineers

Walla Walla, WA 99362
No. of

Copies

D. Goeke

Columbia National Wildlife

Refuge Complex

P.O. Box F

Othello, WA 99349

2 Golder Associates, Inc.

4104 148th Avenue NE

Redmond, WA 98052

ATTN: L. Swenson

Library

L. Goldstein

Washington State Department of Ecology

P.O. Box 47600

Olympia, WA 98504

J. Hall

Washington Department of Wildlife

7601 W. Clearwater, Suite 102

Kennewick, WA 99336

2 IT Corporation

1045 Jadwin Avenue, Suite C

Richland, WA 99352

ATTN: J. Chiramonte

D. A. Myers

J. Jabosky

U.S. Bureau of Land Management

Spokane District Office

4217 E. Main Street

Spokane, WA 90202

J. Johnson

National Audubon Society

209 N. Clinton

Walla Walla, WA 99362 
No. of Copies

3 Nez Perce Tribe

P.O. Box 305

Lapwai, ID 83540

ATTN: D. Conrad

S. Harris

D. Powaukee

J. Phillips

Washington State Department of Ecology 7601 W. Clearwater, Suite 102

Kennewick, WA 99336

\section{P. Sleeger}

U.S. Department of Interior

500 NE Multnomah, Suite 600

Portland, OR 97232

C. Soper

The Nature Conservancy

217 Pine Street, Suite 1100

Seattle, WA 98101

K. Sycamore

National Park Service

Pacific NW Region

83 S. King Street

Seattle, WA 98104

D. Teel

Washington State Department of Ecology 7601 W. Clearwater, Suite 102

Kennewick, WA 99336

$2 \quad$ U.S. Fish and Wildlife Service

Olympia Field Office

3704 Griffin Lane SE, Suite 102

Olympia, WA $98501-2192$

ATTN: K. Benkert

D. Kaumheimer
No. of

Copies

\section{ONSITE}

6 U.S. Environmental Protection Agency
P. R. Beaver
B5-01
D. R. Einan
B5-01
D. A. Faulk
B5-01
L. E. Gadbois
B5-01
P. S. Innis
B5-01
D. R. Sherwood
B5-01

26 DOE Richland Operations Office

J. D. Bauer

A5-15

R. F. Brich

A5-55

R. M. Carosino

A4-52

K. V. Clarke

A5-15

P. F. Dunigan, Jr.

A5-15

B. L. Foley

A5-19

E. D. Goller

A5-19

R. D. Hildebrand (10)

A5-55

R. G. Holt

A5-15

R. G. McLeod

A5-19

C. R. Pasternak

A7-27

R. K. Stewart

A5-19

A. E. Teimouri

A5-15

K. M. Thompson

A5-15

P. W. Willison

A4-52

Public Reading Room (2)

A1-65

56 Westinghouse Hanford Company

M. R. Adams

H6-01

R. A. Carlson

H6-03

S. W. Clark

H6-01

J. H. Dunkirk

B3-15

T. W. Ferns (10)

H6-26

G. E. Fitzgibbon

H6-07

M. J. Galbraith

H6-02 
No. of Copies

K. A. Gano

R. P. Henckel

L. C. Hulstrom

A. R. Johnson

W. L. Johnson

C. D. Kramer

A. D. Krug

D. S. Landeen

N. K. Lane

M. J. Lauterbach

K. M. Leonard (10)

J. G. Lucas

R. M. Mitchell

K. L. Peterson

R. C. Roos

M. R. Sackschewsky

J. W. Schmidt

M. R. Schwab

J. A. Stegen

L. C. Tunnell

R. S. Weeks

S. G. Weiss (10)
No. of

Copies

X0-21
H6-02
H6-03
H6-30
H6-04
H6-04
H6-02
H4-14
H6-01
H6-01
H6-22
H6-04
H6-04
H4-14
H6-04
H4-14
H6-30
H6-07
H6-02
H6-22
H6-26
H6-02

$32 \quad$ Pacific Northwest Laboratory

C. A. Brandt

L. L. Cadwell

C. E. Cushing

D. D. Dauble

J. L. Downs (10)

S. L. Friant

D. R. Geist

T. K. Lucas

R. Mazaika

D. A. Neitzel

G. P. O'Connor

K. M. Probasco

W. H. Rickard

L. E. Rogers

C. L. Savard

R. K. Woodruff

Publishing Coordination

Technical Report Files (5)

K6-60

K6-63

K6-54

K6-54

K6-63

K6-52

K6-54

K6-52

K6-63

K6-54

K6-63

K6-52

K6-63

K6-63

K6-86

K6-61

K1-06

Routing

R. M. Ecker

M. J. Graham

SEQUIM

K6-78

P. M. Irving

K6-98

C. S. Sloane

K6-04

P. C. Hays (last) 

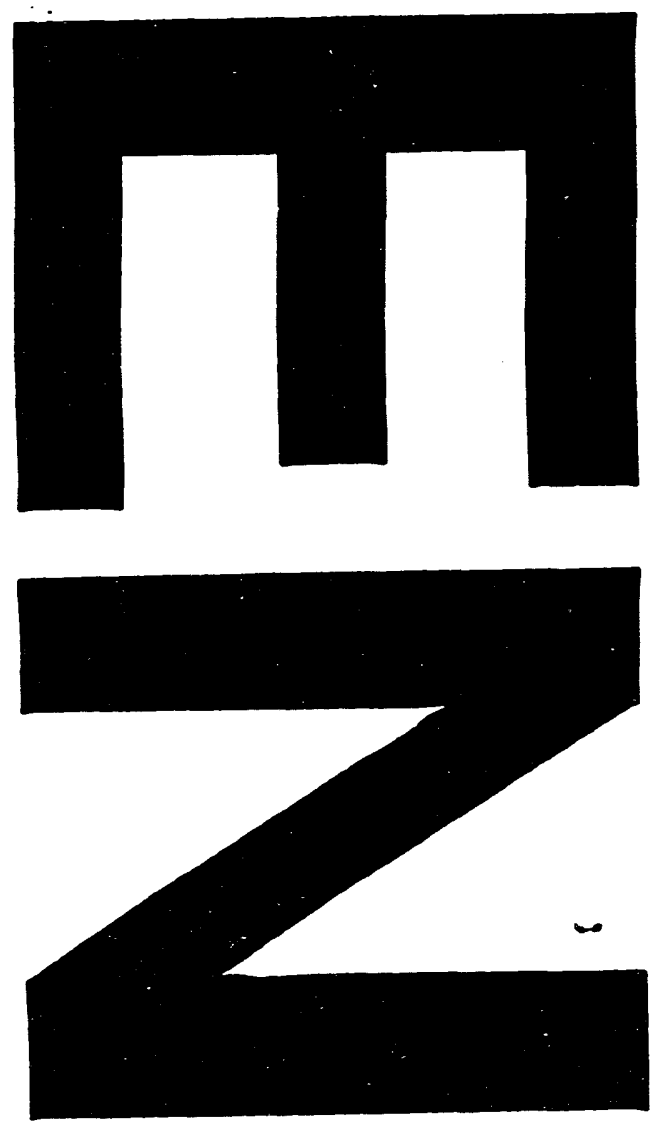

l
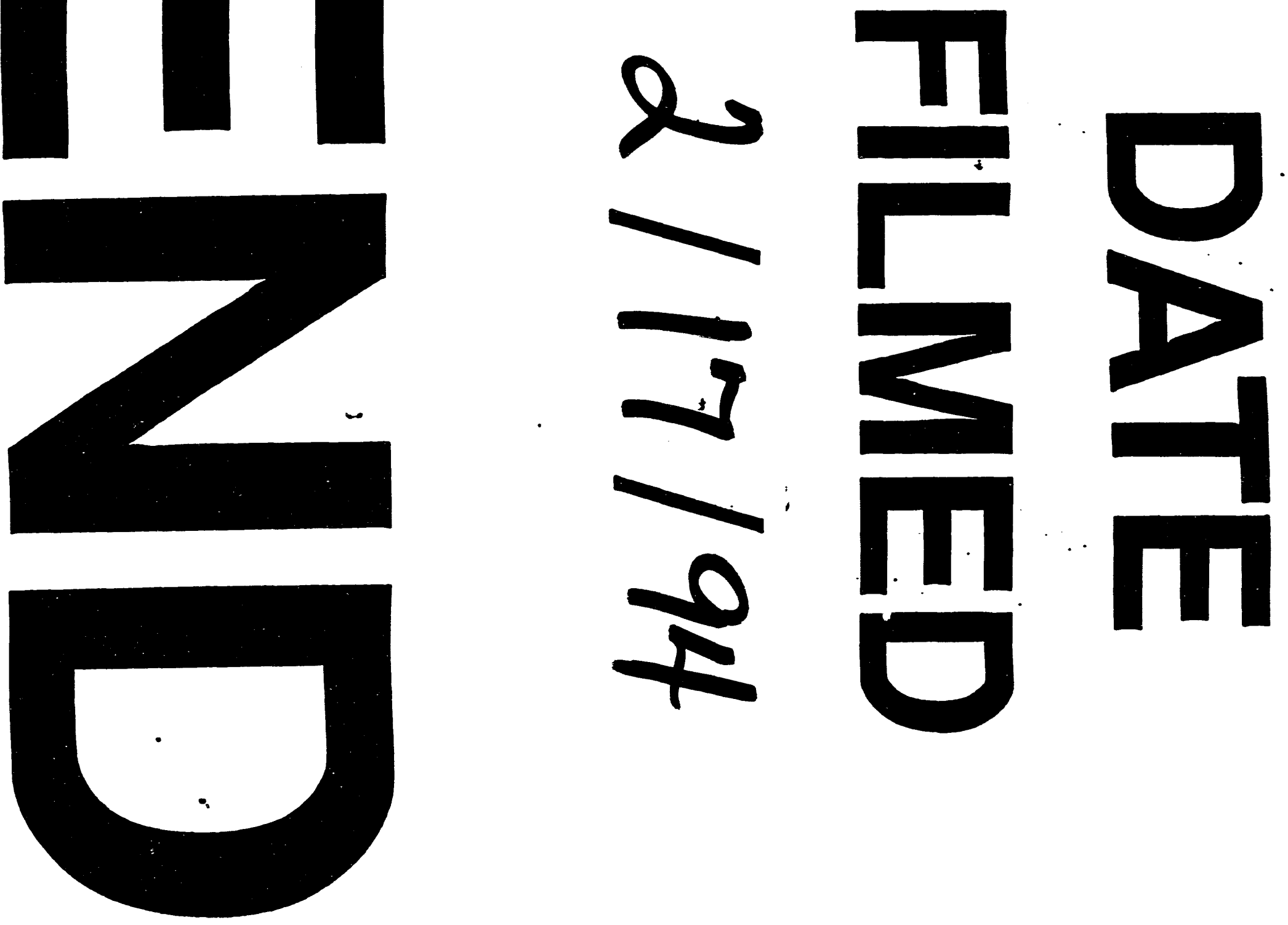
$$
\underline{ }
$$

$\bar{\square}$ 